Prepared in cooperation with the Wisconsin Department of Natural Resources, the City of Madison, Cities in the Waukesha Permit Group, Hydro International, Earth Tech Incorporated, National Sanitation Foundation International, and the U.S. Environmental Protection Agency

\title{
Parking Lot Runoff Quality and Treatment Efficiencies of a Hydrodynamic-Settling Device in Madison, Wisconsin, 2005-6
}
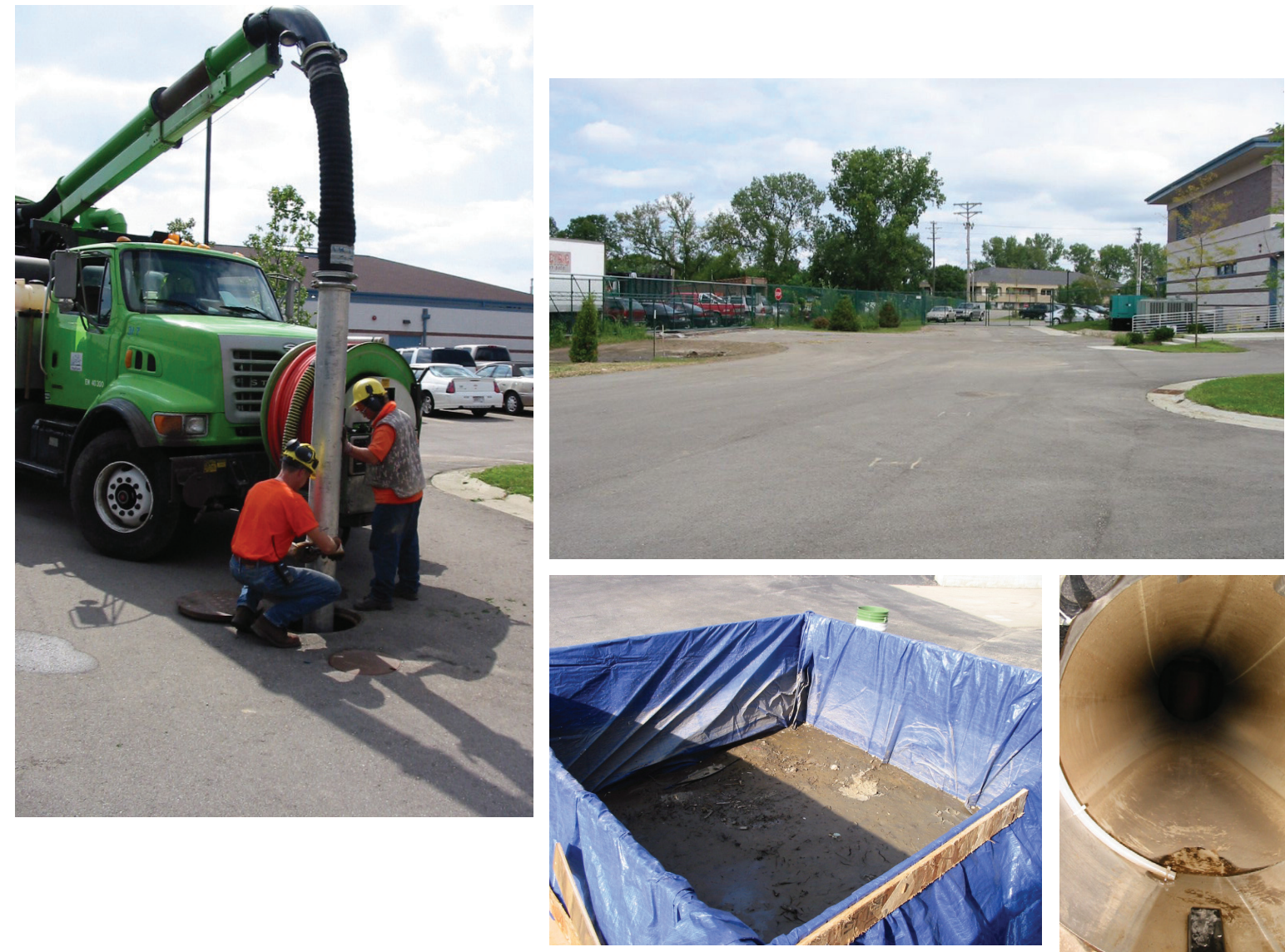

Scientific Investigations Report 2011-5145

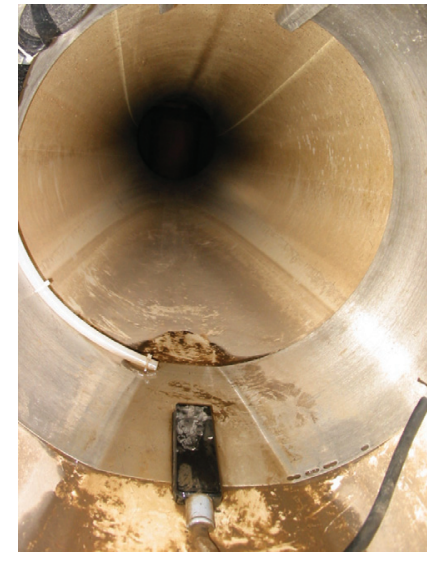





\section{Parking Lot Runoff Quality and Treatment Efficiencies of a Hydrodynamic-Settling Device in Madison, Wisconsin, 2005-6}

By Judy A. Horwatich and Roger T. Bannerman

Prepared in cooperation with the Wisconsin Department of Natural Resources, the City of Madison, Cities in the Waukesha Permit Group, Hydro International, Earth Tech Incorporated, National Sanitation Foundation International, and the U.S. Environmental Protection Agency

Scientific Investigations Report 2011-5145 


\section{U.S. Department of the Interior \\ KEN SALAZAR, Secretary \\ U.S. Geological Survey \\ Marcia K. McNutt, Director}

\section{U.S. Geological Survey, Reston, Virginia: 2012}

For more information on the USGS - the Federal source for science about the Earth, its natural and living resources, natural hazards, and the environment, visit http://www.usgs.gov or call 1-888-ASK-USGS.

For an overview of USGS information products, including maps, imagery, and publications, visit http://www.usgs.gov/pubprod

To order this and other USGS information products, visit http://store.usgs.gov

Any use of trade, product, or firm names is for descriptive purposes only and does not imply endorsement by the U.S. Government.

Although this report is in the public domain, permission must be secured from the individual copyright owners to reproduce any copyrighted materials contained within this report.

Suggested citation:

Horwatich, J.A., and Bannerman, R.T., 2012, Parking lot runoff quality and treatment efficiencies of a hydrodynamicsettling device in Madison, Wisconsin, 2005-6: U.S. Geological Survey Scientific Investigations Report 2011-5145, 35 p. plus $11 \mathrm{app}$.

Cover: A hydrodynamic-settling device installed in an employee parking lot in downtown Madison, Wisconsin. (Photographs from Earth Tech, Inc., September 2005.) 


\section{Contents}

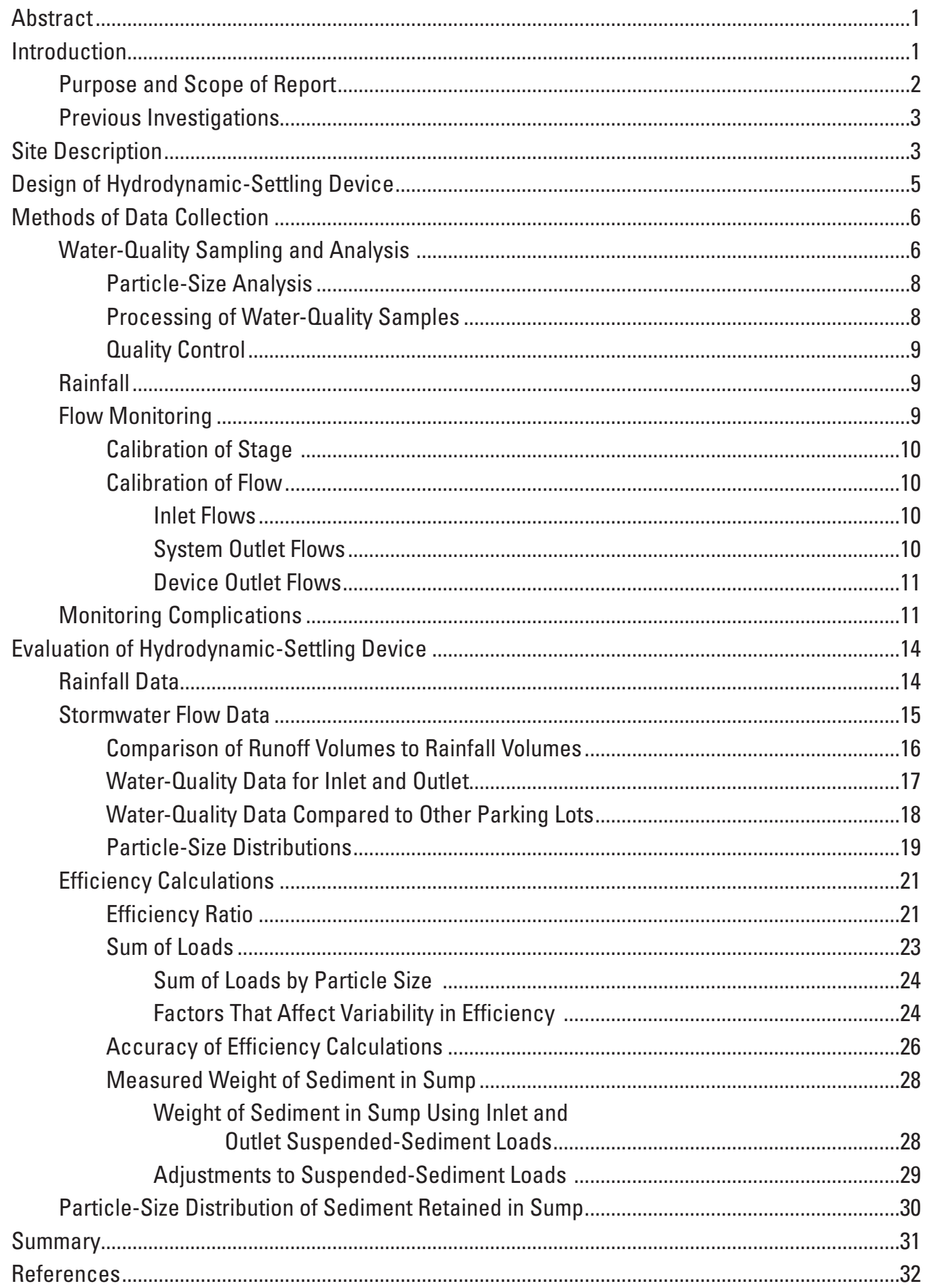




\section{Appendixes 1-11}

1. List of References for Previous Investigations

2. Concentrations of selected water-quality constituents in field-equipment blank samples collect at inlet, outlet, and bypass of hydrodynamic-settling device in Madison, Wisconsin, October 2005 and May 2006

3. Relative percent difference for concentrations of selected water-quality constituents in field-replicate samples collected at inlet and outlet of hydrodynamic-settling device.

4. Precipitation measured by tipping-bucket rain gage at study site during water-quality sample collection from hydrodynamic-settling device in Madison, Wisconsin, November 2005-September 2006

5. Stormwater peak discharge, runoff volumes, and percentage runoff at hydrodynamic-settling device in Madison, Wisconsin, November 2005September 2006

6. Concentrations of suspended sediment, adjusted suspended solids, volatile solids, and dissolved solids in stormwater samples collected at inlet, outlet, and bypass of hydrodynamic-settling device in Madison, Wisconsin, Nobember 2005-August 2006

7. Concentrations of selected water-quality constituents and physical properties in stormwater samples collected at inlet, outlet, and bypass of hydrodynamicsettling device in Madison, Wisconsin, November 2005-September 2006

8. Mean concentrations of selected polycyclic aromatic hydrocarbons in stormwater samples collected at inlet and outlet of hydrodynamic-settling device in Madison, Wisconsin, November 2005-August 2006.

9. Particle-size distributions in stormwater samples collected at inlet, outlet, and bypass of hydrodynamic-settling device in Madison, Wisconsin, November 2005-August 2006.

10. Loads of suspended solids, adusted suspended solids, volatile solids, and dissolved solids in stormwater samples collected at inlet, outlet, and bypass of hydrodynamic-settling device in Madison, Wisconsin, November 2005August 2006

11. Loads of selected water-quality constituents in stormwater samples collected at inlet, outlet, and bypass at hydrodynamic-settling device in Madison, Wisconsin, November 2005-August 2006

\section{Figures}

1. Diagram showing location of study area in Madison, Wisconsin, drainage area of parking lot, inlets, manholes, hydrodynamic-settling device, and storm-sewer pipes.

2. Schematic diagram of hydrodynamic-settling device.

3. Diagram of flow system and location of flow monitoring and water-quality sampling equipment for hydrodynamic-settling device..

4. Graphs showing comparison of flow measured using dye dilution fluorometer and inlet area-velocity meter for two runoff events, May 9 and 16, 2006

5. Graph showing stormwater flow volumes at flow system outlet corrected by dye dilution in relation to inlet flow volumes, 2006 
7. Photograph showing debris on speed bump overtopping watershed divide with stormwater runoff from adjacent City of Madison recycling facility, August 2006 .........13

6. Photograph showing watershed barrier (speed bump) installed to prevent runoff from City of Madison recycling facility..... 13

8. Photograph showing blockage of culvert draining the Madison recycling facility adjacent to the Madison Water Utility Administration Building, August 2006. . .13

9. Graph showing cumulative rainfall for study site (2005-6) in relation to cumulative frequency for all rainfall greater than 0.05 inch (1949-92) determined on basis of National Oceanic and Atmospheric Administration rainfall gage at Dane County Regional Airport, Madison, Wisconsin

10. Graph showing comparison of percentage of parking lot runoff and rainfall for hydrodynamic-settling device, November 2005-August 2006

11. Graph showing particle-size distributions determined at inlet and outlet of hydrodynamic-settling device for selected runoff events, November 2005August 2006.

12. Graph showing removal efficiency of suspended solids and total solids as a function of peak flow for hydrodynamic-settling device system, November 2005August 2006.

13. Graph showing variability in suspended-solids removal efficiency relative to percentage of particle sizes greater than 125 micrometers for hydrodynamicsettling device, November 2005-August 2006

14. Photograph showing slurry tank for drying material vacuumed from bottom of hydrodynamic-settling device

\section{Tables}

1. Characteristics of drainage area that contribute runoff to hydrodynamic-settling device at Madison Water Utility Administration Building, Madison, Wisconsin ...............3

2. Limits of detection and analytical methods for inorganic constituents analyzed in samples collected at the hydrodynamic-settling device in Madison, Wisconsin .............7

3. Limits of detection and analytical methods for polycyclic aromatic hydrocarbons analyzed in samples collected at the hydrodynamic-settling device in Madison, Wisconsin

4. Comparison of monthly rainfall between U.S. Geological Survey rain gage at study site and National Oceanic and Atmospheric Administration rainfall gage at Dane County Regional Airport, Madison, Wisconsin, November 2005September 2006.

5. Summary statistics for selected water-quality constituents in samples collected at inlet, outlet, and bypass of hydrodynamic-settling device, Madison, Wisconsin, November 2005 through August 2006

6. Comparison of geometric mean concentrations from this study with geometric mean and median concentrations observed in other parking lot studies in Wisconsin and Michigan.

7. Average particle-size distributions determined at inlet and outlet of hydrodynamic-settling device for selected runoff events, Madison, Wisconsin, November 2005-August 2006

8. Summary of flow-weighted average concentrations, control system efficiency ratios, and device efficiency ratios for the hydrodynamic-settling device in Madison, Wisconsin, November 2005-August 2006. 
9. Summary of constituent loads and percentage efficiency for hydrodynamicsettling device in Madison, Wisconsin, November 2005-August 2006

10. Particle-size distribution for Maine Department of Transportation road sand

11. Sum of loads and percentage of suspended-sediment load reduction by particle size for hydrodynamic-settling device and bypass system in Madison, Wisconsin, November 2005-August 2006

12. Comparison of average particle-size distributions between 3 runoff events and 17 other runoff events for parking lot in Madison, Wisconsin, November 2005-August 2006.

13. Monitored and estimated loads after concentrations of suspended sediment was adjusted for three largest particle sizes at inlet and outlet of hydrodynamicsettling device in Madison, Wisconsin, November 2005 and September 2006

14. Particle-size distribution for sediment samples collected in hydrodynamicsettling device in Madison, Wisconsin, September 2006 


\section{Conversion Factors}

\begin{tabular}{|c|c|c|}
\hline Multiply & By & To obtain \\
\hline \multicolumn{3}{|c|}{ Length } \\
\hline inch (in.) & 25.4 & millimeter $(\mathrm{mm})$ \\
\hline foot $(\mathrm{ft})$ & 0.3048 & meter $(\mathrm{m})$ \\
\hline mile (mi) & 1.609 & kilometer (km) \\
\hline micrometer $(\mu \mathrm{m})$ & 0.00003937 & inch (in.) \\
\hline \multicolumn{3}{|c|}{ Area } \\
\hline acre & 4,047 & square meter $\left(\mathrm{m}^{2}\right)$ \\
\hline acre & 0.4047 & hectare (ha) \\
\hline \multicolumn{3}{|c|}{ Volume } \\
\hline cubic foot $\left(\mathrm{ft}^{3}\right)$ & 0.02832 & cubic meter $\left(\mathrm{m}^{3}\right)$ \\
\hline liter (L) & 0.2642 & gallon (gal) \\
\hline \multicolumn{3}{|c|}{ Flow rate } \\
\hline cubic foot per second $\left(\mathrm{ft}^{3} / \mathrm{s}\right)$ & 0.028317 & cubic meter per second $\left(\mathrm{m}^{3} / \mathrm{s}\right)$ \\
\hline inch per hour (in/hr) & 25.40 & millimeter per hour (m/hr) \\
\hline \multicolumn{3}{|c|}{ Mass } \\
\hline pound, avoirdupois (lb) & 0.4536 & kilogram (kg) \\
\hline $\operatorname{gram}(\mathrm{g})$ & 0.03527 & ounce (oz) \\
\hline \multicolumn{3}{|c|}{ Mass per area } \\
\hline pound per cubic foot $\left(\mathrm{lb} / \mathrm{ft}^{3}\right)$ & 16.02 & kilogram per cubic meter \\
\hline \multicolumn{3}{|c|}{ Specific gravity } \\
\hline gram per cubic centimeter $\left(\mathrm{g} / \mathrm{cm}^{3}\right)$ & 62.43 & pound per cubic foot $\left(\mathrm{lb} / \mathrm{ft}^{3}\right)$ \\
\hline
\end{tabular}

Temperature in degrees Celsius $\left({ }^{\circ} \mathrm{C}\right)$ may be converted to degrees Fahrenheit $\left({ }^{\circ} \mathrm{F}\right)$ as follows: ${ }^{\circ} \mathrm{F}=\left(1.8 \mathrm{x}^{\circ} \mathrm{C}\right)+32$.

Temperature in degrees Fahrenheit $\left({ }^{\circ} \mathrm{F}\right)$ may be converted to degrees Celsius $\left({ }^{\circ} \mathrm{C}\right)$ as follows: ${ }^{\circ} \mathrm{C}=\left({ }^{\circ} \mathrm{F}-32\right) / 1.8$.

Concentrations of chemical constituents in water are given either in milligrams per liter (mg/L) or micrograms per liter $(\mu \mathrm{g} / \mathrm{L})$.

Particle sizes of sediment are given in micrometers $(\mu \mathrm{m})$. A micrometer is one-thousandth of a millimeter.

Concentrations of sieved solids as a dried weight are in milligrams per kilogram (mg/kg). 


\section{Abbreviations or Acronyms Used in this Report}

\begin{tabular}{|c|c|}
\hline DCRA & Dane County Regional Airport \\
\hline $\mathrm{DCu}$ & dissolved copper \\
\hline DP & dissolved phosphorus \\
\hline $\mathrm{DZn}$ & dissolved zinc \\
\hline EPA & Environmental Protection Agency \\
\hline ETV & Environmental Technology Verification \\
\hline IJC & International Joint Commission \\
\hline LOQ & limit of quantification \\
\hline MLE & Maximum Likelihood Estimation \\
\hline NOAA & National Oceanic and Atmospheric Administration \\
\hline NPDES & National Pollution Discharge Elimination System \\
\hline NSF International & National Sanitation Foundation International \\
\hline NURP & Nationwide Urban Runoff Program \\
\hline $\mathrm{PAH}$ & polycyclic aromatic hydrocarbon \\
\hline PVC & polyvinyl chloride \\
\hline PSD & particle-size distribution \\
\hline $\mathrm{R}^{2}$ & correlation coefficient \\
\hline RPD & relative percent difference \\
\hline $\mathrm{SLOH}$ & State Laboratory of Hygiene \\
\hline SM & standard methods \\
\hline SOL & summation of loads \\
\hline SRS & standard reference sample \\
\hline SS & suspended sediment \\
\hline $\mathrm{TCu}$ & total recoverable copper \\
\hline TDS & total dissolved solids \\
\hline ТP & total phosphorus \\
\hline TSS & total suspended solid \\
\hline $\mathrm{TZn}$ & total recoverable zinc \\
\hline USGS & U.S. Geological Survey \\
\hline VSS & volatile suspended solids \\
\hline WDNR & Wisconsin Department of Natural Resources \\
\hline
\end{tabular}




\title{
Parking Lot Runoff Quality and Treatment Efficiencies of a Hydrodynamic-Settling Device in Madison, Wisconsin, 2005-6
}

\author{
By Judy A. Horwatich ${ }^{1}$ and Roger T. Bannerman ${ }^{2}$
}

\section{Abstract}

A hydrodynamic-settling device was installed in 2004 to treat stormwater runoff from a roof and parking lot located at the Water Utility Administration Building in Madison, Wis. The U.S. Geological Survey, in cooperation with the Wisconsin Department of Natural Resources, the City of Madison, cities in the Waukesha Permit Group, Hydro International, Earth Tech, Inc., National Sanitation Foundation International, and the U.S. Environmental Protection Agency, monitored the device from November 2005 through September 2006 to evaluate it as part of the U.S. Environmental Protection Agency's Environmental Technology Verification Program. Twenty-three runoff events monitored for flow volume and water quality at the device's inlet and outlet were used to calculate the percentage of pollutant reduction for the device. The geometric mean concentrations of suspended sediment (SS), "adjusted" total suspended solids (TSS), total phosphorus (TP), dissolved phosphorus (DP), total recoverable zinc (TZn), and total recoverable copper $(\mathrm{TCu})$ measured at the inlet were $107 \mathrm{mg} / \mathrm{L}$ (milligrams per liter), $92 \mathrm{mg} / \mathrm{L}, 0.17 \mathrm{mg} / \mathrm{L}, 0.05$ $\mathrm{mg} / \mathrm{L}, 38 \mathrm{ug} / \mathrm{L}$ (micrograms per liter), and $12 \mathrm{ug} / \mathrm{L}$, respectively, and these concentrations are in the range of values observed in stormwater runoff from other parking lots in Wisconsin and Michigan.

Efficiency of the settling device was calculated using the efficiency ratio and summation of loads (SOL) methods. Using the efficiency ratio method, the device reduced concentrations of SS, and DP, by 19, and 15, percent, respectively. Using the efficiency ratio method, the device increased "adjusted" TSS and TZn concentrations by 5 and 19, respectively. Bypass occurred for 3 of the 23 runoff events used in this assessment, and the bypass flow and water-quality concentrations were used to determine the efficiency of the bypass system. Concentrations of SS, "adjusted" TSS, and DP were reduced for the system by 18,5 , and 18, respectively; however, TZn increased by 5 percent. Some of the TSS concentrations were "adjusted" to add the particles that remained on the sieves during sample processing. The loads of SS, "adjusted" TSS, and

\footnotetext{
${ }^{1}$ U.S. Geological Survey.
}

\footnotetext{
${ }^{2}$ Wisconsin Department of Natural Resources.
}

DP were reduced using the SOL method for the settling device by 38,9 , and 19 percent, respectively, and TZn increased by 13 percent. For the bypass system, the loads of SS, "adjusted" TSS, and DP had percentage reductions of 39, 12, 22, respectively, however TZn increased by 4 percent. The SOL method produced percentage reductions for SS and "adjusted" TSS that were twice those for the efficiency ratio method. Removing the two large runoff events on August 23 and 24, 2006, from the SOL calculation brought the reduction for SS down to 16 and increased "adjusted" TSS by 4 percent. The two large runoff events were anomalies in that the runoff volumes and dissolved solids concentrations were greatly increased by overflow from an adjacent recycling facility.

The SOL method was used to determine the percentage of SS load reduction for six different particle sizes for both the settling device and bypass system. Essentially no load reduction was observed for particles less than 125 micrometers $(\mu \mathrm{m})$ in diameter, and about a 90-percent reduction occurred for particle sizes greater than $250 \mu \mathrm{m}$ in diameter. The large removal efficiencies for particle sizes greater than $250 \mu \mathrm{m}$ in diameter were further supported by the fact that more than 80 percent of the particle sizes trapped in the sump were greater than 250 $\mu \mathrm{m}$ in diameter. These results support the claim by the manufacturer of achieving a large percentage load reduction for particle sizes greater than $250 \mu \mathrm{m}$ in diameter.

\section{Introduction}

Urban runoff can adversely affect aquatic systems by altering a stream's normal flow regime, destroying fish habitat, and degrading water quality (Booth and Reinelt, 1993; Horner and others, 1994; Masterson and others 1994; Pitt and others, 1995, Bannerman and others, 1996; Wang and others, 2001; Weber and Bannerman, 2004; Richards and others, 2006). To help control the effects of urbanization on aquatic systems, the Wisconsin Department of Natural Resources (WDNR) has promulgated a series of stormwater performance standards that attempt to mitigate both water-quantity and water-quality 
effects associated with urban runoff (Wisconsin Administrative Code NR 151, 2004). Water-quality benefits are based on reduction of total suspended solids (TSS) loads by 80 percent for new development, 40 percent for redevelopment, and 40 percent for a retrofit reduction. Wisconsin's municipalities will be required to meet these performance standards as part fulfillment of their U.S. Environmental Protection Agency (EPA) National Pollution Discharge Elimination System (NPDES) Phase II permit. Municipalities can select from among a number of different types of proprietary and nonproprietary types of stormwater control practices to achieve the TSS performance standards, but to reduce the uncertainty in the selection process, more information is needed about their ability to reduce TSS loads and their total cost.

To help reduce the uncertainty in the selection of proprietary stormwater control practices, a number of products have been evaluated in Wisconsin (Waschbusch and others, 1999, Horwatich and others, 2004, 2010). These evaluations included both filtration and hydrodynamic-settling devices, which use sedimentation as the principle mechanism for removing TSS. These types of devices are usually installed underground, which makes them attractive for achieving TSS reduction goals at sites with limited above-ground space, such as retrofit or redevelopment sites. Results from these evaluations are being used by the WDNR to develop technical standards for both proprietary filters and hydrodynamic-settling devices. The technical standards provide criteria for proper design and installation. Also, the evaluations help calibrate and verify models used to identify the TSS reduction assigned to each installation.

As part of the continuing effort to reduce the uncertainty in the selection of proprietary stormwater control practices, the U.S. Geological Survey (USGS) in cooperation with the WDNR, the City of Madison, cities in the Waukesha Permit Group, Hydro International (Portland, ME), Earth Tech, Inc. (Madison, Wis.), National Sanitation Foundation International (NSF International), and the EPA Environmental Technology Verification (ETV) Program evaluated the effectiveness of a hydrodynamic-settling device, the Downstream Defender ${ }^{\circledR}$, which is manufactured by Hydro International. This single chamber device is designed to treat stormwater runoff and limit the resuspension of entrained sediment. The newly installed device was located at the City of Madison Water Utility Administrative Building site. Most of the drainage area consists of an employee parking lot and roofs. Monitoring of flow was conducted at the inlet, outlet, and bypass to the device from November 2005 through September 2006.

Because the evaluation described in this report is part of the ETV program, it followed EPA-approved monitoring protocols, and the results are nationally distributed by the EPA (U.S. Environmental Protection Agency, 2002a). The ETV program sets a national focus on verifying manufacturer's claims for the performance of commercially available stormwater control practices. The EPA cooperates with the NSF International as its verification partner, and NSF International is in charge of the following tasks: (1) create a national protocol to test wet-weather flow technologies, (2) contract independent groups to evaluate the effectiveness of the stormwater-treatment practices of interest, (3) review and implement the verification testing plans, and (4) make study results available to the general public (U.S. Environmental Protection Agency, 2002a). A separate ETV report was prepared with the results from the evaluation described herein (U.S. Environmental Protection Agency, 2007).

The purpose of the evaluation described in this report was to provide information needed by municipalities to reduce the uncertainty they might have in using proprietary practices to achieve their pollutant reduction goals. The overall purpose of the evaluation can be divided into three specific objectives. One specific objective is to determine the efficiency of the hydrodynamic-settling device in reducing the contaminant loads in runoff from the site. A second specific objective was to collect sufficient data to calibrate and verify models estimating TSS reduction by hydrodynamic-settling devices and to add to the database characterizing the quality of runoff from an office complex. This objective required adding particle-size distributions to the constituent list. A third specific objective was to verify the manufacture's claim for TSS reduction.

\section{Purpose and Scope of Report}

This report describes the methods and results from the evaluation of the efficiency of a hydrodynamic-settling device installed at the City of Madison Water Utility Administration Building site. The methods include collecting flow volume and water-quality data at the inlet, outlet, and bypass locations for the device. Methods for collecting rainfall data at the site are also described. Results are presented in the form of concentrations and loads of selected constituents at different locations in the hydrodynamic-settling device. Separate procedures are described for using the concentrations and loads to calculate the ability of the device to improve water quality. Results from 23 runoff events were used for the efficiency calculations. Additional calculations are described that test the accuracy of the rainfall data, the flow data, and the water-quality data.

Flow volume and water-quality data used for the efficiency calculations were collected from November 2005 through August 2006. Water-quality samples collected at the inlet, outlet, and bypass locations were analyzed for as many as 31 constituents. These constituents might include particulate and dissolved forms of solids, trace metals, particlesize distributions, and 18 polycyclic aromatic hydrocarbons (PAHs). Some of the constituents had been analyzed by previous studies of similar source areas, and these concentrations were compared with the results from this study. Rainfall records from the closest weather stations were used to evaluate the accuracy of the rainfall data measured at the study site. Sufficient particle-size distribution data were collected at the inlet and outlet to represent the efficiency of the device 
for each particle size. The accuracy of the loads measured at the different sampling locations was evaluated by comparing the difference in the inlet and outlet suspended-sediment (SS) loads to the amount of sediment trapped in the sump of the device.

\section{Previous Investigations}

The USGS has a long history of conducting urban waterquality investigations in Wisconsin. Starting with the EPAfunded International Joint Commission (IJC) study in 1974 (Bannerman and others, 1979) the USGS has been involved continuously with partners in Wisconsin trying to find solutions to urban runoff problems. The IJC study helped characterize the level of pollution contributed from urban areas to the Great Lakes. In 1978, the EPA established the Nationwide Urban Runoff Program (NURP) to assess the water-quality characteristics of urban runoff. When the City of Milwaukee, Wis., was chosen by the EPA as a NURP site, a partnership between the WDNR and the USGS was developed to evaluate urban runoff in Milwaukee. Since the NURP study, the USGS and the WDNR have continued their partnership and have completed more than 16 studies in at least six cities. Other studies have focused on understanding the cause of degradation in urban streams, the level of pollutant control needed to improve the urban resources, evaluating the efficiency of different stormwater control practices, and improving modeling of urban runoff. Results from all of these efforts have assisted Wisconsin and other States in the implementation of more cost-effective stormwater management programs. See appendix 1 for a list of references for these previous investigations.

\section{Site Description}

The hydrodynamic-settling device was installed in the parking lot of the Water Utility Administration Building in Madison, Wis., during the fall of 2004. The utility building is located at 119 East Olin Avenue in Madison. The latitude and longitude coordinates are $43^{\circ} 03^{\prime} 09^{\prime}$ ' $\mathrm{N}$ and $89^{\circ} 22^{\prime} 55^{\prime \prime} \mathrm{W}$ (U.S. Environmental Protection Agency, 2007).

The building grounds cover about 5.5 acres, and 1.91 acres of the grounds drain to the settling device (fig. 1, table 1). The device is sized to treat the runoff from the 1.91 acres. All the runoff from the 1.91 acres is delivered to the device through a storm-sewer collection system. The storm-sewer system that collects the runoff reaching the device consists of 12- and 15-in. diameter concrete pipes. The catch basins do not have sumps, and there are no other stormwater control practices in the area. After leaving the outlet to flow diversion structure, the treated (and bypassed) water enters a wet detention pond also located on the Water Utility property.

Water leaving the wet detention pond flows through the city storm-sewer system to Wingra Creek, which is a tributary to Lake Monona. Wingra Creek is on the WDNR 303(d) impaired waters list (U.S. Environmental Protection Agency, 1998, 2002b). Wingra Creek's impairments are aquatic toxicity and contaminated sediment.

Madison, Wis., has a climate typical of interior North America, with a large annual temperature range and frequent short-period temperature changes. Nearly 60 percent of the approximately 33 in. of average annual rainfall falls in the months of May through September (National Climate Data Center, 2003). The average amount of snowfall is $44 \mathrm{in.}$

Table 1. Characteristics of drainage area that contribute runoff to hydrodynamic-settling device at Madison Water Utility Administration Building, Madison, Wisconsin.

\begin{tabular}{lcc}
\hline \multicolumn{1}{c}{ Land use } & Acres & $\begin{array}{c}\text { Total runoff contribution } \\
\text { (percent) }\end{array}$ \\
\hline $\begin{array}{l}\text { Parking lot and } \\
\text { roadway }\end{array}$ & 1.05 & 55 \\
Roofs & 0.49 & 26 \\
Lawn & 0.29 & 15 \\
Sidewalks & 0.08 & 4 \\
\hline
\end{tabular}




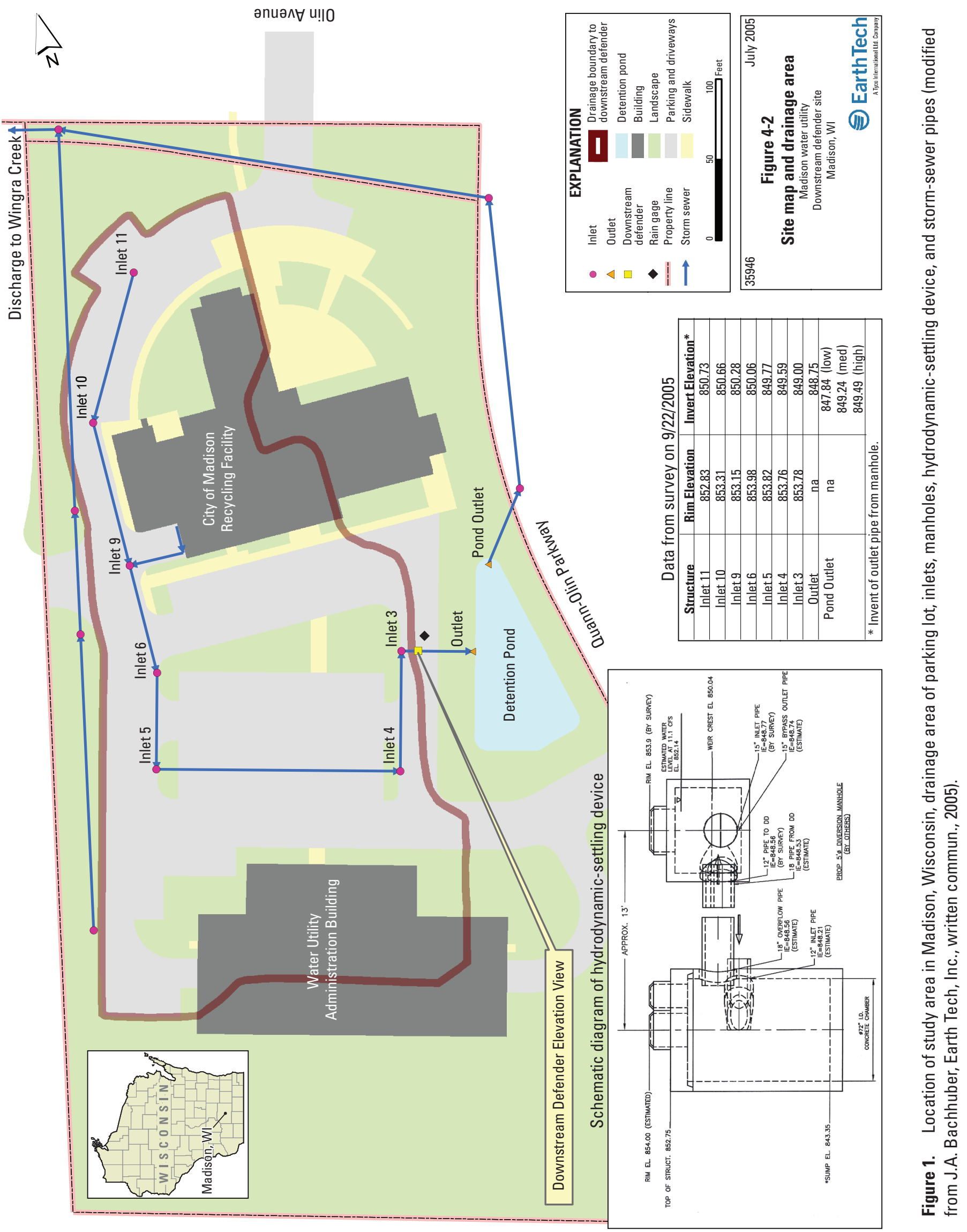




\section{Design of Hydrodynamic-Settling Device}

The 6-ft diameter hydrodynamic-settling device installed at the Madison Water Utility Administration Building site is designed to remove settleable solids, oil, and floatables in stormwater runoff. The device has no moving parts and no external power requirements. It consists of a cylindrical concrete vessel, with polypropylene internal components, a 304 stainless-steel support frame, and connecting hardware (fig. 2). The concrete vessel is a standard precast cylindrical manhole with a tangential inlet pipe that is installed below ground. Two ports at ground level provide access for inspection and clean out of stored floatables and sediment. The internal components consist of two concentric hollow cylinders (the dip plate and center shaft), an inverted cone (the center cone), a benching skirt, and a floatables lid (U.S. Environmental Protection Agency, 2007).

The device is designed to collect accumulated sediment outside the treatment flow path and beneath the benching skirt. The internal components help minimize turbulence and hydraulic-head losses, which can enhance separation and prevent resuspension of previously stored sediment. The center cone is one component that protects resuspension of previously stored sediment by redirecting the main flow upwards and inwards under the dip plate into the inner annular space (fig. 2).
The installation includes a flow diversion structure that is located approximately $13 \mathrm{ft}$ north of the device (fig. 3). Stormwater runoff from the drainage area enters the 5-ft diameter flow diversion manhole by a 1.125 -ft polyvinyl chloride (PVC) pipe (fig. 3, point A). The manhole housed a 0.97-ft PVC device inlet pipe (point B), a 1.4-ft PVC device outlet pipe (point C), a 1.1-ft system outlet PVC pipe (point D), and a 2-ft high weir wall (point E). When flow is bypassed over the weir, the hydrodynamic-settling device and the diversion structure are acting as a system. Because the settling device used for the study is sized to treat flows up to $3 \mathrm{ft}^{3} / \mathrm{s}$, the diversion structure will bypass when flows exceed $3 \mathrm{ft}^{3} / \mathrm{s}$ up to $8 \mathrm{ft}^{3} / \mathrm{s}$.

The hydrodynamic-settling device installed at the study site is designed to remove settleable solids from stormwater runoff. Generally, the removal efficiency of the device decreases or possible negative with increasing flow rates, finer particles, and cooler water temperatures. For runoff at $15^{\circ} \mathrm{C}$ and flow rates up to $3 \mathrm{ft}^{3} / \mathrm{s}$, the device will remove over 80 percent of settleable solids when the specific gravity equals 2.65 with a particle-size distribution (PSD) similar to the Maine Department of Transportation's road sand. Hydro International defines "settleable sediment" as particles greater than $62 \mu \mathrm{m}$ in size. Because 80 percent of the particles in the road sand PSD are about $290 \mu \mathrm{m}$ in diameter or greater, the device can achieve the performance standard by trapping mostly particles in the medium sand-size fraction or greater (U.S. Environmental Protection Agency, 2007). The device has a sediment storage capacity of $56.7 \mathrm{ft}^{3}$.

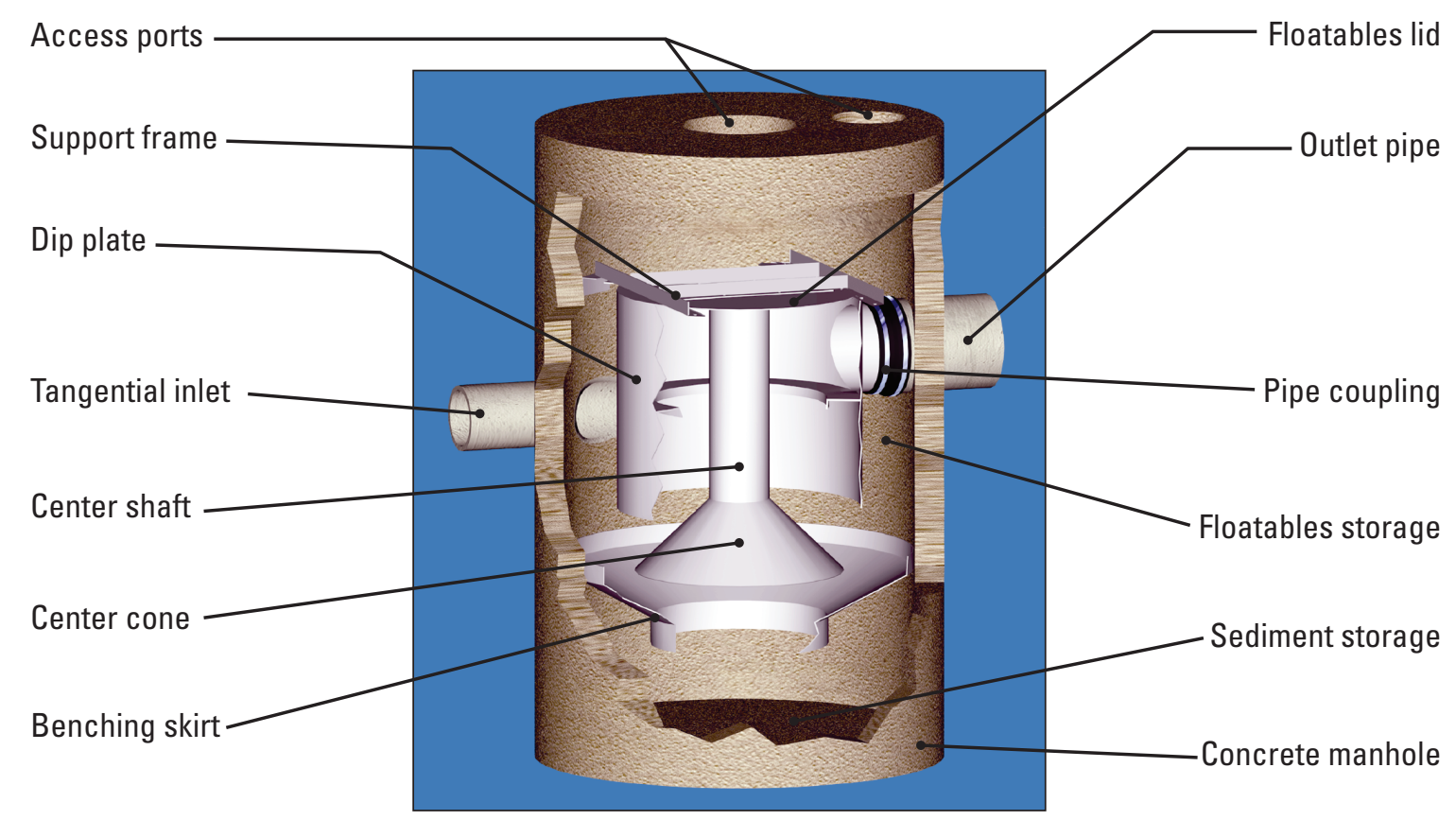

Figure 2. Hydrodynamic-settling device. 


\section{Methods of Data Collection}

Stormwater runoff was measured and collected at the inlet, outlet, and bypass pipes of the hydrodynamic-settling device. Each pipe was equipped with automated stormwaterquality samplers and instruments to measure stage height and velocity. Rainfall depths were collected by use of a tippingbucket rain gage. Measurement, control, and storage of data were done by way of electronic data loggers. Data were automatically retrieved twice daily with telephone modems.

\section{Water-Quality Sampling and Analysis}

Water-quality samples were collected from the inlet, outlet, and bypass weir (sampling points B, C, and E, fig. 3) of the device over 11 months. Station identification numbers and names for each sampling location are 430310089225401 Downstream Defender Unit Inlet at Madison, Wis. (point B); 430310089225402 Downstream Defender System Outlet at Madison, Wis. (point C); and 430310089225403 Downstream Defender Unit Outlet at Madison, Wis. (point E). The analytical constituents were selected based on the performance information from the manufacturer and the regulated constituents that the WDNR might want to control in the future (tables 2 and 3). Samples were analyzed at the Wisconsin State Laboratory of Hygiene (SLOH), which participates in the USGS Standard Reference Sample (SRS) Program (Woodworth and Connor, 2003).

Automatic samplers were programmed to collect flowweighted samples from points B, C, and E (fig. 3). To collect samples at the inlet (point B), a water-quality sample line was installed $2 \mathrm{ft}$ downstream from where flow enters the device, and to collect a sample at the outlet, a water-quality

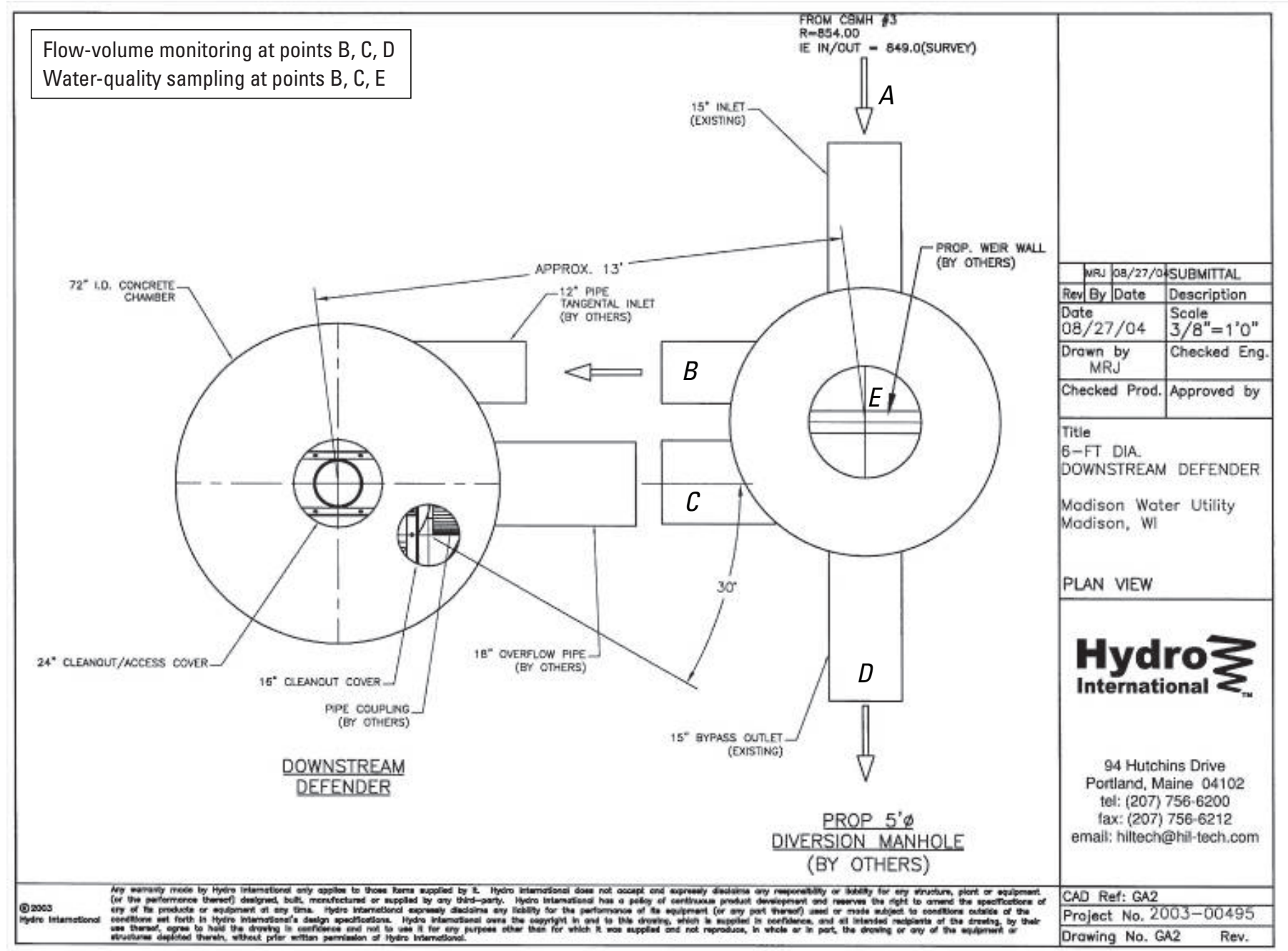

Figure 3. Flow system and location of flow monitoring and water-quality sampling equipment for hydrodynamic-settling device (from Hydro International, Portland, Maine, 2004). 
sample line was installed $2 \mathrm{ft}$ upstream from where flow exits the device (point $\mathrm{C}$ ). To sample bypassing runoff events, a water-quality sample line was installed $1 \mathrm{in}$. below the top of the upstream side weir wall (point E). All sample lines were Teflon lined and installed perpendicular to flow and approximately $1 \mathrm{in}$. from the bottom of the pipe. The automatic samplers were programmed with a pre-sample purge and rinses cycle before each sample. Sample lines were not replaced between events. The data logger in the monitoring station was programmed to initiate a subsample for a predefined volume of flow; consequently, more subsamples were collected for large-volume runoff events than for small-volume runoff events. Flow-weighted sampling allowed for the collection of one composite sample per stormwater runoff event, consisting of numerous subsamples collected throughout the course of the event. This approach resulted in a single flow-weighted or "event mean" concentration for each runoff event. The volume between subsamples was determined such that a minimum of five 1-L subsamples were collected for each event. The maximum sampler capacity was 401 -L subsamples into 4 glass bottles. For events greater than or equal to 0.2 in. of rainfall and a minimum of five 1-L subsamples, the subsamples were processed for all constituents (tables 2 and 3); otherwise, subsamples were processed for concentrations of SS, TSS, and total dissolved solids (TDS). Samples were processed according to the churn-splitting procedure described by Horowitz and others (1997) and further described in this report.

Table 2. Limits of detection and analytical methods for inorganic constituents analyzed in samples collected at the hydrodynamic-settling device in Madison, Wisconsin.

[mg/L, milligrams per liter; P, phosphorus; $\mu \mathrm{g} / \mathrm{L}$, micrograms per liter; NA, not applicable]

\begin{tabular}{|c|c|c|c|c|}
\hline Constituent or characteristic & Unit & $\begin{array}{l}\text { Limit of } \\
\text { detection }\end{array}$ & $\begin{array}{c}\text { Limit of } \\
\text { quantification }{ }^{1}\end{array}$ & Method \\
\hline Dissolved solids, total & $\mathrm{mg} / \mathrm{L}$ & 50 & 167 & SM2540C ${ }^{2}$ \\
\hline Suspended solids, total & $\mathrm{mg} / \mathrm{L}$ & 2 & 7 & EPA $160.2^{3}$ \\
\hline Volatile solids, total & $\mathrm{mg} / \mathrm{L}$ & 2 & 7 & EPA $160.2^{3}$ \\
\hline Suspended sediment & $\mathrm{mg} / \mathrm{L}$ & 2 & 7 & ASTM D3977-97² \\
\hline Phosphorus, dissolved & $\mathrm{mg} / \mathrm{L}$ as $\mathrm{P}$ & 0.005 & 0.016 & EPA $365.1^{3}$ \\
\hline Phosphorus, total & $\mathrm{mg} / \mathrm{L}$ as $\mathrm{P}$ & 0.005 & 0.016 & EPA $365.1^{3}$ \\
\hline Calcium, total recoverable & $\mathrm{mg} / \mathrm{L}$ & 0.02 & 0.07 & EPA $200.7^{2,3}$ \\
\hline Magnesium, total recoverable & $\mathrm{mg} / \mathrm{L}$ & 0.03 & 0.7 & EPA $200.7^{2,3}$ \\
\hline Zinc, dissolved ${ }^{4}$ & $\mathrm{mg} / \mathrm{L}$ & 1 & 3 & EPA $200.9^{2}$ \\
\hline Zinc, total recoverable ${ }^{4}$ & $\mathrm{mg} / \mathrm{L}$ & 1 & 3 & EPA $200.9^{2}$ \\
\hline Copper, dissolved & $\mathrm{mg} / \mathrm{L}$ & 1 & 3 & $\mathrm{SM} 3113 \mathrm{~B}^{2}$ \\
\hline Copper, total recoverable & $\mathrm{mg} / \mathrm{L}$ & 1 & 3 & SM3113B ${ }^{2}$ \\
\hline Wet-sieve of sediment & NA & NA & NA & Burton $^{5}$ \\
\hline Coulter counter of sediment & NA & NA & NA & Burton $^{5}$ \\
\hline Laser diffraction of sediment & NA & NA & NA & Burton $^{5}$ \\
\hline Microfiltration of sediment & NA & NA & NA & Burton $^{5}$ \\
\hline
\end{tabular}

\footnotetext{
${ }^{1}$ Limit of quantification is the low standard in the calibration curve.

${ }^{2}$ American Public Health Association and others (1989); SM, standard methods.

${ }^{3}$ U.S. Environmental Protection Agency (EPA) (1986)

${ }^{4}$ The first 3 events had limit of detection and limit of quantification of 16 and 50, respectively.

${ }^{5}$ Burton and Pitt (2002).
} 
Table 3. Limits of detection and analytical methods for polycyclic aromatic hydrocarbons analyzed in samples collected at the hydrodynamic-settling device in Madison, Wisconsin.

[All data in micrograms per liter determined by use of method SW8310 in American Public Health Association and others (1989) $\left.{ }^{1}\right]$

\begin{tabular}{llc}
\hline \multicolumn{1}{c}{ Constituent } & Limit of detection & $\begin{array}{c}\text { Limit of } \\
\text { quantification }\end{array}$ \\
\hline Acenaphthene & 0.064 & 0.20 \\
Acenaphthylene & 0.11 & 0.34 \\
Anthracene & 0.031 & 0.10 \\
Benzo[ $a]$ anthracene & 0.093 & 0.30 \\
Benzo[a]pyrene & 0.16 & 0.52 \\
Benzo[b]fluoranthene & 0.13 & 0.41 \\
Benzo[g,h,i]perylene & 0.14 & 0.44 \\
Benzo[k]fluoranthene & 0.12 & 0.38 \\
Chrysene & 0.027 & 0.09 \\
Dibenzo[a,h]anthracene & 0.034 & 0.11 \\
Fluoranthene & 0.11 & 0.35 \\
Fluorene & 0.52 & 1.7 \\
Indeno[ $[1,2,3-c d]$ pyrene & 0.093 & 0.30 \\
1-Methylnaphthalene & 0.064 & 0.20 \\
2-Methylnaphthalene & 0.049 & 0.16 \\
Naphthalene & 0.042 & 0.13 \\
Phenanthrene & 0.093 & 0.30 \\
Pyrene & 0.11 & 0.34 \\
\hline I A & & \\
\hline
\end{tabular}

\footnotetext{
${ }^{1}$ American Public Health Association and others (1989); SM, standard methods.

${ }^{2}$ Limit of quantification is the low standard in the calibration curve.
}

\section{Particle-Size Analysis}

In July 2004, the USGS Wisconsin Water Science Center adopted a new method for particle-size analysis. Previous methods required a large sample volume to provide enough sediment for analysis. Previous methods were not designed for the relatively small amounts of sediment observed in stormwater samples. The new method requires only about a liter of sample and has been incorporated into the evaluation described in this report. The new particle-size analysis uses a two-step protocol suggested for stormwater by Burton and Pitt (2002). The protocol was adopted for use in Wisconsin by SLOH.

The first step was to wet sieve the sample for the particle sizes of $500,250,125,63$, and $32 \mu \mathrm{m}$ in diameter. All the material remaining on the sieves was then dried and weighed to determine mass. Particles less than $32 \mu \mathrm{m}$ in diameter remaining in the filtrate were further delimited into four additional particle sizes by either using a laser-based diffraction instrument or a Coulter Counter (Beckman Coulter Multisizer 3 particle-size counter; Graham and Beckman Coulter, Inc., 2003). These instruments were used to determine the percentage of sediment by mass with diameters less than $14,8,5$, and $2 \mu \mathrm{m}$ in diameter. Laser diffraction was used on the samples at the beginning of this evaluation, and the Coulter Counter was used on all the remaining samples. Other researchers have used a Coulter counter to evaluate particle sizes in stormwater (Burton and Pitt, 2002). The Coulter counter was calibrated by microfiltering replicate samples with polycarbonate filters.

\section{Processing of Water-Quality Samples}

A new procedure was used to improve the accuracy and precision of measured quantity of particulate constituents in samples that contained a large amount of sand-sized particles (greater than $125 \mu \mathrm{m}$ in diameter). Previous studies have shown that using a churn to partition samples with large quantities of sand had the potential to cause a positive bias and to lessen the precision of constituent concentrations associated with particulates (Horowitz and others, 1997). The use of a wet-sieving process decreased these errors for sediment-associated constituent concentrations (Selbig and others, 2007). This process consisted of pouring a known quantity of sample through sieves of 125,250 , and $500 \mu \mathrm{m}$ in diameter before churning the aqueous portion. Material collected on sieves was sent to the SLOH in individual bottles to be dried and weighed. Dried material from each of the sieves was then combined and processed for total recoverable metals and phosphorus. This process was used for 10 of 23 runoff events, which were determined by stirring the samples and observing at least $2 \mathrm{~g}$ of material at the bottom of the bottle after 1 minute. For samples from the 10 runoff events, large amounts of material dropped to the bottom of the glass bottle within 1 minute of stirring the sample. The aqueous portion of the sample that passed through the sieves was processed using typical USGS churning procedures (Horowitz and others, 1997). Concentrations of SS presented in this report may include sieved material.

Sample results of the sieved mass were added back to the aqueous portion to determine a mean concentration for the runoff event by using the following equation (Selbig and others, 2007):

$$
C_{I}=((S m / 1000) \times C s) / V,
$$

where

$C_{I}$ is concentration of sieved solids, in milligrams per liter;

$S_{m}$ is mass of sieved solids after drying, in grams;

$C_{s}$ is concentration of constituent in sieved solids, in milligrams per kilogram; and

$V$ is volume of sieved water, in liters. 
The sieving process eliminates sand-size particles resulting in a negative bias when TSS is analyzed. Conventional TSS analysis may include particles as large as $500 \mu \mathrm{m}$ in diameter. To adjust TSS ("adjusted" TSS) concentrations that include these larger particles, an independent study was conducted by the USGS. The independent study compared the TSS aliquot method to the concentration of SS whole-bottle method. Concentration of SS, TSS, and PSD were processed on 13 nonsieved samples. From this analysis, particles of 63 $\mu \mathrm{m}$ in diameter or less were found to have similar concentrations of SS and TSS. However, for particles larger than $63 \mu \mathrm{m}$ in diameter, TSS had lower concentrations than SS. The TSS to SS particle-size ratios were 0.29 for $500 \mu \mathrm{m}$ in diameter, 0.32 for $125 \mu \mathrm{m}$ in diameter, and 0.57 for $250 \mu \mathrm{m}$ in diameter, (William Selbig, U.S. Geological Survey, written commun., 2006). Therefore, SS particle-size concentrations of the sieved samples were multiplied by the respective ratios and then added to the TSS concentration. The "adjusted" TSS concentrations in this report reflect this process.

\section{Quality Control}

The field-equipment blank and replicate samples were collected at the inlet and outlet of the settling device and analyzed for the same constituents as those for runoff samples (appendix. 2). The equipment blank procedure passed deionized water through the sampler and processed the water through the churn splitter to validate clean sampling procedures (Wilde, 2006). Blank samples were collected at the beginning and midpoint of the study to validate cleansampling procedures.

Three equipment blank samples (at points B, D, and E) were collected to test clean-sampling procedures. The first equipment blank set was collected before sampling began (blank set 1) and the second set between runoff events 7 and 8 (blank set 2). The blank 1 sample contained no detectable concentrations at the settling device inlet, device outlet, and bypass wall (points B, D, and E, fig. 3). The blank set 2 sample had detectable concentrations of dissolved copper (DCu), total recoverable copper $(\mathrm{TCu})$, dissolved zinc (DZn), and total recoverable zinc (TZn) at the three sample points, but the dissolved concentrations were less than the limit of quantification (LOQ). The TCu concentrations at the three sampling points exceeded the LOQ, but $\mathrm{TCu}$ concentrations were not used to evaluate the device for concentration reductions. Quality-control samples collected directly from the sampler and from the bottle of blank water were analyzed for dissolved, but not total, concentrations; analyses resulted in detections below or at limit of quantification (appendix. 2).

Analytical precision is a measurement of how much an individual measurement deviated from a mean of replicate measurements. Replicate churn samples were collected during several stormwater runoff events to quantify the variability or precision in the churn splitting and analytical procedures. The relative percent difference (RPD) was calculated to evaluate precision in procedures after sample collection.

The relative percent difference equation is:

$$
R P D=\left[\left(X_{1}-X_{2}\right) / \bar{X}\right] \times 100,
$$

where

$X_{1}$ is concentration of constituent in a sample;

$X_{2}$ is concentration of a constituent in a duplicate sample; and

$\bar{X}$ is mean value of $X_{1}$ and $X_{2}$.

Replicate samples were collected during runoff events 5 and 17 to quantify variability in the sampling process. The RPD target for TSS was 30 percent or less; for recoverable metals, the RDP target was 25 percent or less (appendix 3). In replicates for runoff event 17, the RDP target of 25 percent was exceeded for TZn. For all other constituents a relatively low RPD was reported.

\section{Rainfall}

A tipping-bucket rain gage was used for continuous rainfall measurement to measure the volume and intensity of rainfall for each storm. A data logger recorded the number of bucket tips ( 0.009 in. per tip) every 60 seconds. This gage was not designed to record frozen precipitation, so measurements during periods of snowfall and freezing rainfall were not used. Calibration records showed there was no need to adjust rainfall data. All rainfall amounts are listed in appendix 4. To accurately record rainfall amounts during varying intensities, a microprocessor in the rain gage used a built-in polynomial to correct for the intensity, which was based on the tipping bucket's mechanism (Design Analysis Associates, 2001).

The rain gage was $10 \mathrm{ft}$ north of the hydrodynamicsettling device (fig. 1). It was mounted on a 2 -in. round pipe raised $10 \mathrm{ft}$ above ground. The rain gage was affixed to the Water Utility's security fence. During two rain-gage calibrations, debris was cleaned from inside the gage.

\section{Flow Monitoring}

Area-velocity flow meters that use continuous wave Doppler technology were mounted inside the pipes at flow-volume monitoring points B, C, and D (fig. 3) to measure stage, velocity, and flow volume. The flow meter at point $\mathrm{D}$ measures flow from the outlet pipe (point $\mathrm{C}$ ) and the flow that bypasses the weir wall (point E). A stand-alone stage pressure transducer and temperature probe were installed on the weir (point E). Stage from this probe was used to initiate the bypass sampling routine when a given stage threshold was reached. The bypass sample tube was located on the upstream side of the weir wall. 


\section{Calibration of Stage}

Corrections were applied to stage measurements (October 4, 2005, and May 10, 2006) that reflect differences between water-surface elevations measured manually and those measured with the area-velocity flow meters. Calibration procedures consisted of inflating balls in the pipes near points A and B (fig. 3) to seal off a catchment area upstream of the device. Flow meters (points B, C, and D) were calibrated simultaneously by moving all three meters into the catchment area. Using a garden hose, water stages inside the catchment area were increased by increments of 0.1 to $0.15 \mathrm{ft}$. Ten to 15 readings were taken at each flow meter. These measurements were then compared to what was recorded by the respective flow meters. Accuracy of the stage records, on average, was estimated to be within \pm 2 percent for the three flow meters.

Stage measurements were also checked periodically under low flow or standing water conditions. The device never completely drained, and offsets were applied directly to the flow meters on March 31, 2006, to account for the standing water conditions. Before this date, corrections were made to the stored stage data. Stage calibration on May 10, 2006, concluded all meters were recording correctly; therefore, no stage corrections were necessary.

The stand-alone stage pressure transducer on the weir wall was calibrated on May 10, 2006. The design of the probe prevented stage from being recorded until water reached a height of $0.58 \mathrm{ft}$. The stage was offset by $0.84 \mathrm{ft}$.

\section{Calibration of Flow}

Stormwater runoff was measured at the inlet, outlet, and bypass pipes of the device. A dye dilution system was installed to calibrate flow rate at the device inlet (point B). The device outlet and system outlet (points C and D) were corrected using the calibrated values from the device inlet flows.

\section{Inlet Flows}

In April 2006, an automatic dye dilution system was installed to calibrate flow. A pump that injected a dye of a known concentrations was mounted in pipe at point $\mathrm{A}(10 \mathrm{ft}$ upstream from the weir wall, fig. 3). A fluorometer that samples a mixture of stormwater and dye was mounted alongside the device inlet sampling line (a fluorometer measures the concentration of dye fluorescence). A separate gage house for sampling dye and recording data was located adjacent to the sampling gage houses. A dye-dilution event was triggered when a given stage threshold was reached at device inlet.

The equation to convert dye concentrations to flow follows:

$$
Q=q \times C / c,
$$

where

$Q$ is flow being measured, in cubic feet;

$q$ is injection rate, in milliliters per minute;

$C$ is concentration of injected dye, in percent by volume; and

$c$ is concentration of measure, in micrograms per liter.

Runoff events from May 9, 11, and 16 produced more than 650 sample points of calibration at the inlet meter. Comparison of the inlet area/velocity flow (fig.4, point B) and the dye dilution flow yielded $\mathrm{a} \pm 8$ percent difference per event in flows ranging from 0.03 to $0.41 \mathrm{ft}^{3}$ (fig. 4). Results from these events concluded that the device inlet meter was recording flow accurately for the majority of flows in the calibration range. Fourteen percent of the peak flows were higher than the dye-dilution calibration ranges, however accurate stages were recorded for the entire pipe depth during the static-stage calibration therefore higher flows should be within the +8 percent. Flow meters at the settling device and system outlets could not be calibrated by dye dilution because it was unclear how the dye would mix inside of the device.

\section{System Outlet Flows}

Five of the 26 events sampled recorded stormflow bypassing the hydrodynamic-settling device and passing over the weir wall (point E, fig. 3). To estimate the amount of flow bypassing the settling device to the meter at point $\mathrm{D}$, a relation correlating flows between the calibrated inlet meter (point B) and the system outlet meter (point D) was established. This relation was based on four assumptions: (1) no time delay from the inlet and system outlet, (2) only the rises in the hydrograph were used (this eliminated inaccuracy with meters located backwater from the detention pond), (3) flows that recorded bypassing were not included in the relation, and (4) runoff events before March 31, 2006, were not used (there was a shift in stage before this date; therefore, there was a different stage-flow relation). A scatter plot of flows from the system outlet (point D) to the device inlet (point B) indicated that the system outlet flows were small (fig. 5). A regression line of $y=1.1557 x+0.0326$ for a stage above $0.05 \mathrm{ft}$ was used to correct flows at the system outlet. Several other regressions fit a higher flow regime but produced larger errors for overall flows. For events that did not include bypass flow, the average difference between the volume of flow measured at the device inlet and the volume of flow measured at the system outlet after the downstream area-velocity data was adjusted by -2 percent. For events without bypassing, the average difference between the inlet and the adjusted system outlet flows were -2 percent. 


\section{Device Outlet Flows}

Flows from the device outlet (point C) flowmeter were not used to calculate loads for three reasons: (1) flows from device outlet and inlet should be equal, and the inlet meter was calibrated with dye dilution; (2) the device outlet flows overestimated inlet flow; and (3) bypassing conditions may affect the device outlet.

\section{Monitoring Complications}

Backwater from Pond. It was noticed in the fall of 2005 that stormwater was taking several hours to drain out of the device. There was standing water at the system outlet that could have affected the device performance. The detention pond (downstream from the device) was backing water into the manhole. In January 2006, the detention pond control structure was widened to reduce pond elevation.

No Flow Data Spikes. Programming changes between the data logger and the velocity meter were added that omitted data spikes during no flow. Communications from the area-velocity meter to the data logger were managed through serial string translation. During periods of no flow, data were recorded for the first minute of the hour. When particles were not available for the area-velocity meter, the meter could not correctly determine the velocity within that minute; therefore, the data logger translated the velocity data as an extremely high or low data point. To replace the high or low data point
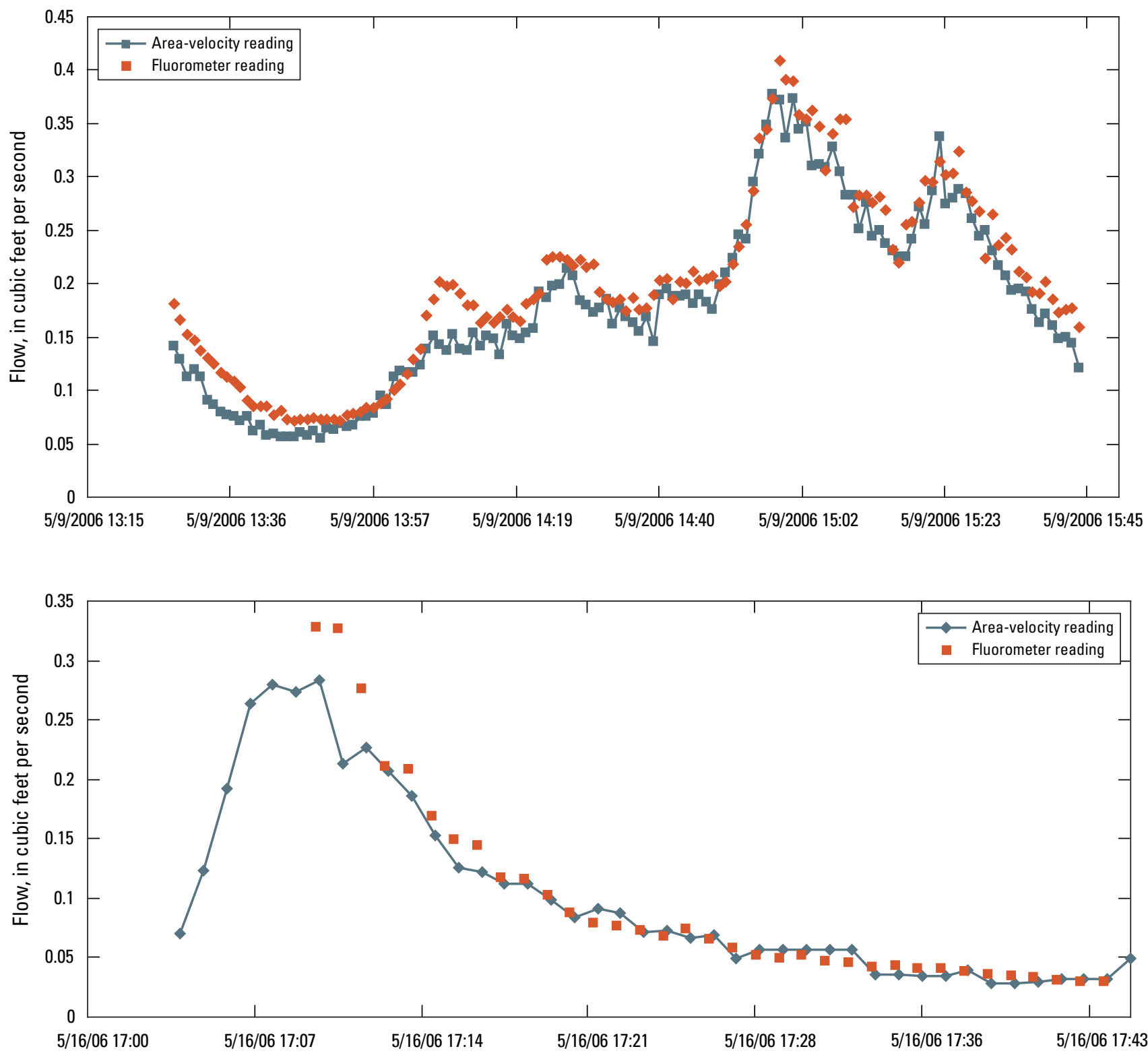

Figure 4. Comparison of flow measured using dye dilution fluorometer and inlet area-velocity meter for two runoff events, May 9 and 16, 2006. 


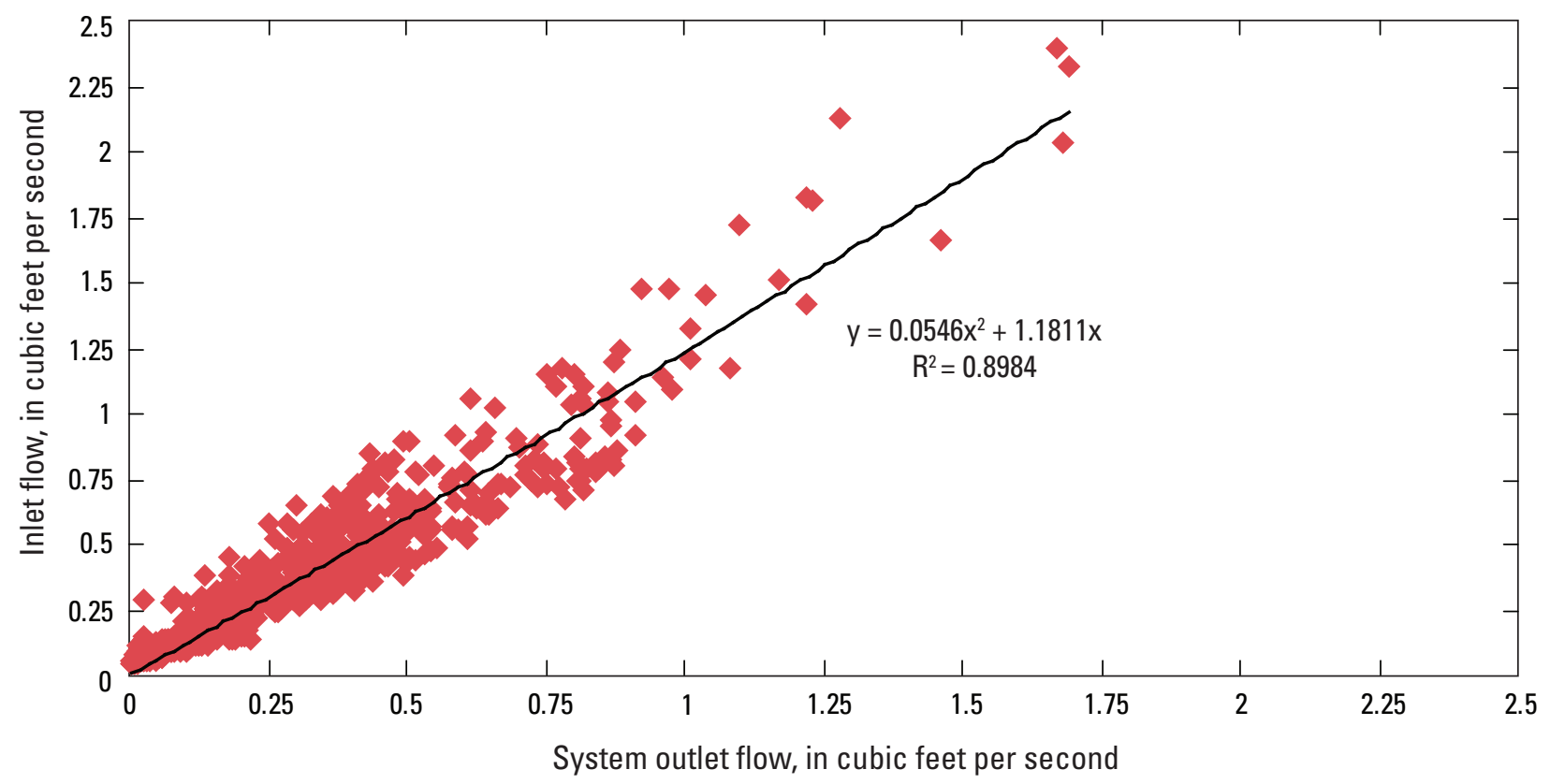

Figure 5. Graph showing stormwater flow volumes at flow system outlet corrected by dye dilution in relation to inlet flow volumes, 2006.

with the last valid velocity recorded by the area-velocity meter, high and low cutoff thresholds were programmed into the data logger. To validate removal of these high or low data points, the velocity data recorded by the data logger were compared to velocity recorded by the internal memory of the area-velocity meter. The area-velocity meter stored 15 -second data for approximately 2 days then overwrote it with new data. Programming changes were made in April 2006.

Power Failures. During the summer of 2006, a few runoff events were missed due to power failures with the samplers. High summer temperatures increased the power needs to cool refrigerators. When the sampler tried to take a sample, there was not enough power to turn on the pumps, resulting in power failures. Adding an extra battery to the system alleviated this problem.

Rodent Damage. Sample tubing was replaced at the inlet sampler in June 2006 due to damage from a rodent. This caused a runoff event on June 10, 2006, to be missed.

Water Temperature Probe Failure. A temperature probe mounted near the bypass wall did not record correctly after May 1, 2006. Temperature readings from another monitoring site, 3 mi northeast of the settling device, were substituted for the remaining events. The substituted probe was installed in May 2006 at a downtown Madison, Wis., parking lot stormwater monitoring site.

Hydrograph Errors for Two Runoff Events. It was noticed that the ends of two flow event hydrographs showed discrepancies in flow; there was more flow at the inlet sampler than at the outlet sampler (events for August 24 and 25, 2006). To determine which meter was in error, stage versus velocity plots were made for several sampled runoff events. From these plots, the inlet and system outlet meters produced a regression equation with correlation coefficients $\left(\mathrm{R}^{2}\right)$ of 0.97 and 0.93 , respectively, but the system outlet meter had greater scattered. By inserting the events in question on the regression plot, volumes were visibly low. The tail end of the system outlet hydrograph was corrected for those two events by replacing the low volume with the recorded inlet volume.

Overflow from Adjacent Recycling Facility. West of the Madison Water Utility Administration Building is a City of Madison recycling facility with outside storage of yard and brush waste. Most of this storage area is impervious. During the first inspections of the study site, it was noticed that some of the runoff from the recycling facility could potentially enter the drainage area being monitored. To reduce the chances of this additional runoff from entering the study area, the City of Madison constructed a 3-in. high speed bump diversion across the driveway connecting the two properties (fig. 6).

Blockage of Culvert Draining Adjacent Recycling Facility. During the last month of the monitoring period, the pipe designed to drain a large portion of the adjacent recycling facility became clogged with sediment. This pipe (fig. 1) is located in a grassy depressed area on the west end of the study area parking lot (figs. 7 and 8). Visual observation of the debris line around this pipe indicated that the depression would fill with runoff and overflow into the drainage area for the monitoring site. Based on site inspections, the extent of additional drainage could be as much as 4 acres for a total drainage area of 5.9 acres. The additional runoff volume would vary with rainfall factors such as depth and intensity and with extent of blockage at the inlet. The additional flow would not decrease the accuracy of the flow meters, but the higher flows could increase the chances of some runoff bypassing the settling device. 


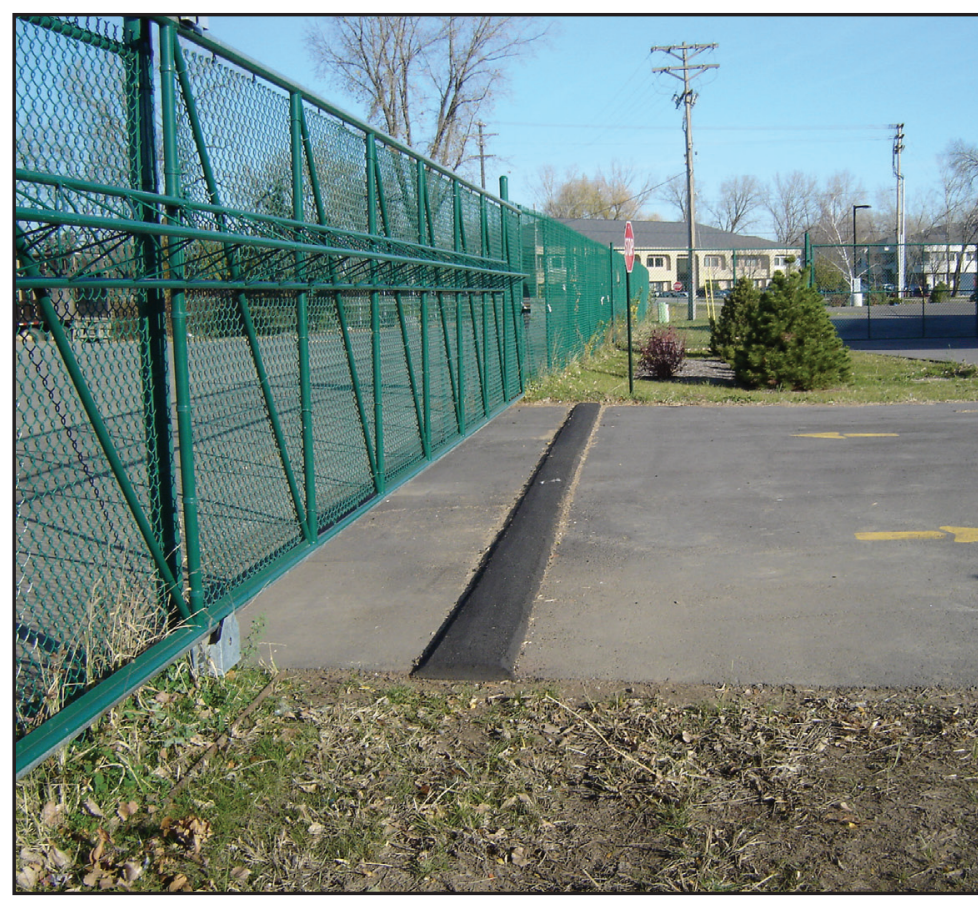

Figure 6. Watershed barrier (speed bump) installed to prevent runoff from City of Madison recycling facility (fenced area to left of photograph).

Figure 7. Debris on speed bump overtopping watershed divide with stormwater runoff from adjacent City of Madison recycling facility, August 2006.

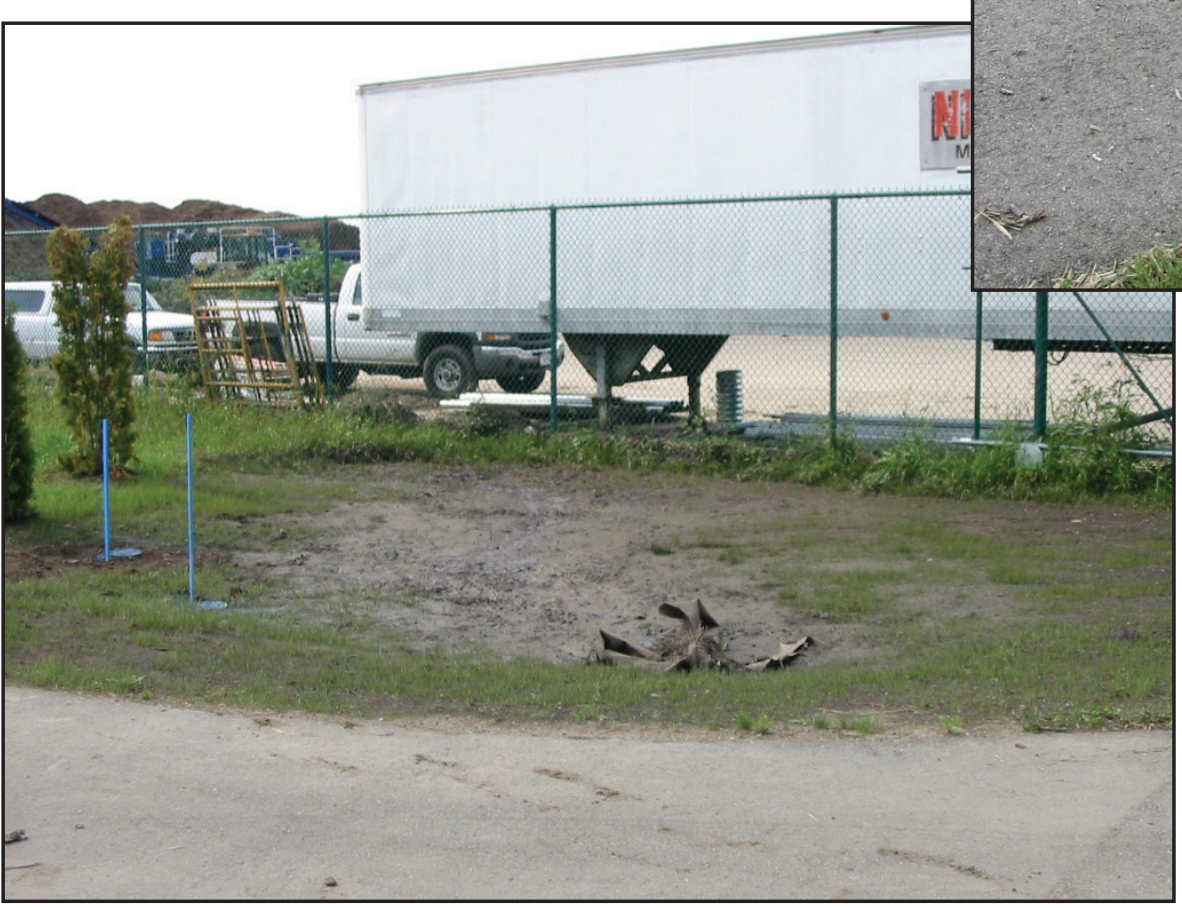

Figure 8. Blockage of culvert draining the Madison recycling facility adjacent to the Madison Water Utility Administration Building, August 2006. 


\section{Evaluation of Hydrodynamic-Settling Device}

Rainfall, flow volume, particle-size, and water-quality data were all important in evaluating the effectiveness of the hydrodynamic-settling device. A comparison of monitored rainfall depths and long-term trends in rainfall depths helped determine if the monitoring data were representative of rainfall patterns in Madison. The flow data were needed to determine the volumes of runoff entering and leaving the settling device and bypass system. The ratio of runoff volumes to rainfall volumes was used to help test the accuracy of the runoff-flow data. Both flow volume and constituent concentrations were needed to evaluate the efficiency of the settling device. Particle-size data helped explain the magnitude of the efficiency determined for the device.

\section{Rainfall Data}

For the study period of November 5, 2005, to September 12,2006 , the rain gage on the study site recorded 71 rainfall events (appendix 4). Because the rain gage could not be used to measure frozen rainfall accurately, the data set in appendix 4 does not include any events in December 2005, January 2006, and February 2006. In addition to the rainfall depths, appendix 4 includes the rainfall volumes, maximum 15 - and 30-minute rainfall intensities, the erosivity index (a measure of the erosive force of a specific rainfall), and the number of days without rain before each event. Rainfall data collected at the site were compared to National Oceanic and Atmospheric Administration (NOAA) data collected at the Dane County Regional Airport (DCRA), which is about $6 \mathrm{mi}$ from the study site (table 4).

The difference between the total from the USGS (onsite) rainfall data and the 2005-6 total from the DCRA rainfall data was less than 1 percent. This indicates that the rain gage at the study site was comparable to the DCRA rainfall data, where larger differences generally occurred for individual months, but localized convective storms can cause substantial differences over distances as small as $6 \mathrm{mi}$. The rainfall at the Madison Water Utility Administration Building was 3.5 in. higher than the long-term (1971-2000) average at DCRA (National Oceanic and Atmospheric Administration, 2007).

Probability distributions for USGS and DCRA rainfall data sets were constructed by use of the Weibull plotting position (Helsel and Hirsch, 1992). Rainfall amounts for individual rainfall events were computed for both data sets. Rainfall amounts greater than or equal to $0.05 \mathrm{in}$. (the minimum amount recorded during this evaluation) were ranked from lowest to highest. A cumulative probability distribution then was computed for both data sets by use of the formula:

Table 4. Comparison of monthly rainfall between U.S. Geological Survey rain gage at study site and National Oceanic and Atmospheric Administration rainfall gage at Dane County Regional Airport, Madison, Wisconsin, November 2005-September 2006.

[Rainfall is presented in inches. USGS, U.S. Geological Survey; DCRA, Dane County Regional Airport;- - no data]

\begin{tabular}{lccc}
\hline \multicolumn{1}{c}{ Month and year } & USGS rain gage & DCRA rain gage & DCRA long-term average ${ }^{\mathbf{1}}$ \\
\hline November 2005 & 2.5 & 3.4 & 2.3 \\
December 2005 & - & - & - \\
January 2006 & - & - & - \\
February 2006 & - & 2.3 & 2.3 \\
March 2006 & 1.7 & 4.2 & 3.4 \\
April 2006 & 5.8 & 4.6 & 3.2 \\
May 2006 & 3.8 & 2.3 & 4.0 \\
June 2006 & 1.9 & 4.2 & 3.9 \\
July 2006 & 5.8 & 5.4 & 4.3 \\
August 2006 & 5.1 & 3.3 & 3.1 \\
September 2006 & 3.4 & 30 & 27 \\
Total & 30 & & -1.3 \\
\hline
\end{tabular}

${ }^{1}$ Average from 1971-2000 for Dane County Regional Airport, Madison, Wis. (National Oceanic and Atmospheric Administration, 2007). 


$$
P_{R}=i_{R} /(n+1),
$$

where

$R$ is precipitation event;

$P_{R}$ is probability of an event having precipitation less than that of event;

$i_{R}$ is ranking of event $R$; and

$n$ is total number of events in the data set.

Except for a moderate deviation for rainfall depths between 0.65 and $0.9 \mathrm{in}$., the distribution of the sampled events was very similar to the long-term distribution (fig. 9).

\section{Stormwater Flow Data}

Stormwater flow data were collected for 47 of the 71 rainfall events from November 2005 to September 2006 (appendix 5). All of the flow data were collected during warmweather months. Because the settling device outlet flows (point $\mathrm{C}$ in fig. 3) were not calibrated, the flow from the device outlet was less accurate than the device inlet flows (point B in fig. 3). The stormwater flow data from the settling device outlet were excluded from the data analysis. Because the inlet and outlet flow volumes are the same, the device inlet flows were used to represent the device outlet flows. These flow data were also used to determine (1) peak flow rates at the settling device inlet and system outlet (point D in fig. 3), (2) inlet volume,
(3) volume over the flow splitter weir (point E in fig. 3), and (4) runoff coefficient for the settling device system. Only the flow events on April 16, May 24, July 27, and August 23 and 24,2006 , had enough bypass volume to significantly affect the magnitude of the percentage of runoff.

Most of the data representing flow had a wide range in values. The device inlet peak flows ranged from 0.10 to $2.9 \mathrm{ft}^{3} / \mathrm{s}$ (appendix 5). The system outlet peak flows ranged from 0.04 to $5.8 \mathrm{ft}^{3} / \mathrm{s}$. The maximum peak flows at the system outlet should be higher than the flows at the device inlet because the flow splitter is designed to limit the flows to the device inlet to $3 \mathrm{ft}^{3}$. The runoff volumes at the device inlet ranged from 138 to $17,200 \mathrm{ft}^{3}$ with majority of the volumes greater than $1,000 \mathrm{ft}^{3}$. The volume of the sump below the outlet pipe elevation is about $147 \mathrm{ft}^{3}$, so the storage volume of the device is replaced at least seven times for most flow events.

Water-quality samples were collected for 26 of the 47 flow events with measured flow (appendix 5). The range of rainfall depths for the sampled events was 0.05 to 2.2 in. with a mean of $0.59 \mathrm{in}$. There were 13 runoff events that had rainfall depths less than 0.2 in. Only 5 of the 13 events were sampled because there was insufficient depth of water in the pipe to collect a sample. Twenty-five of the 47 flow events had between 0.2 and 1.0 in. of rainfall, and samples were collected from 13 of them. One was not sampled due to rodent damage on the sample line. There were nine rainfall events greater than 1 in., and eight were sampled; the event not sampled was due

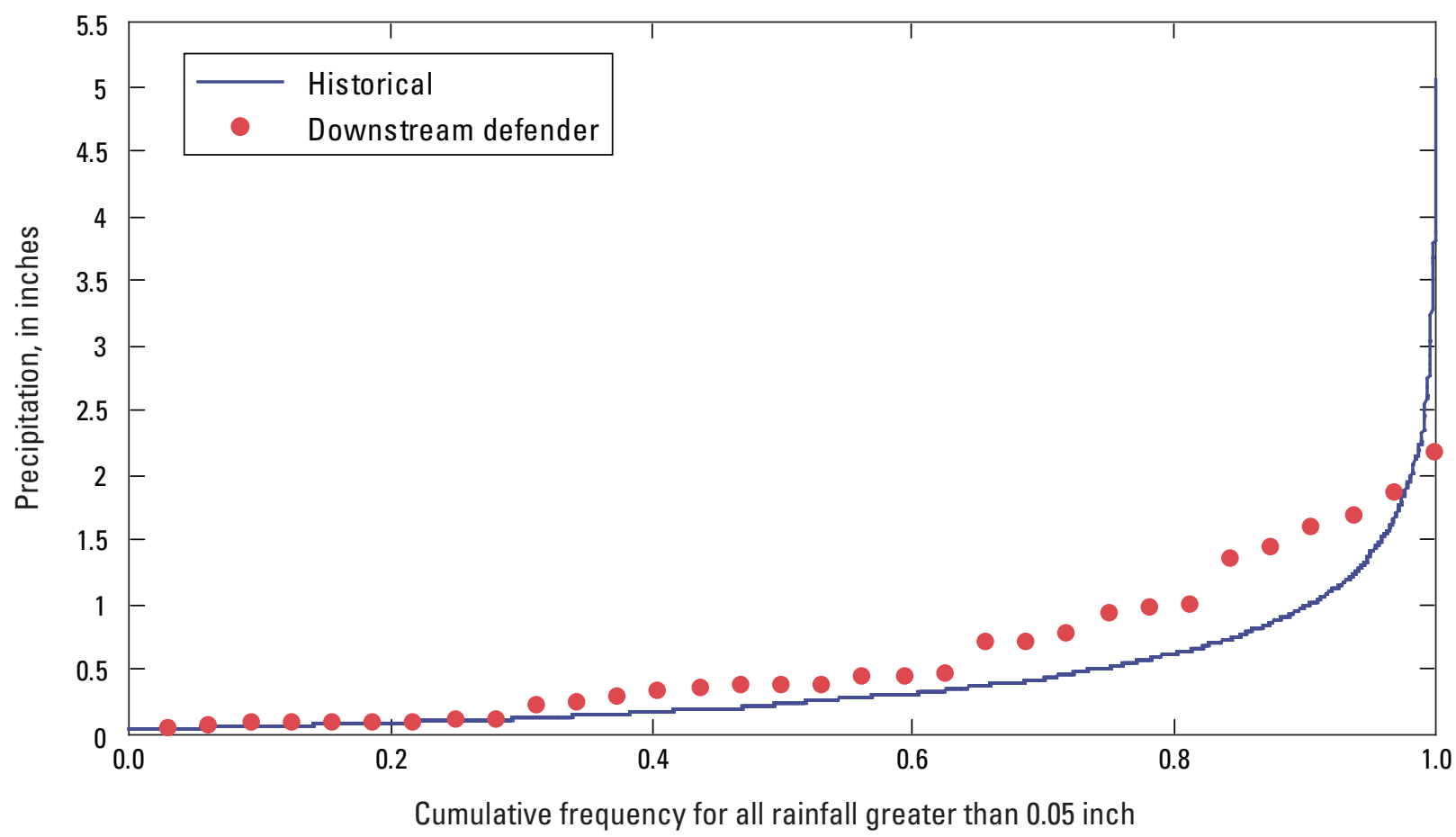

Figure 9. Cumulative rainfall for study site (2005-6) in relation to cumulative frequency for all rainfall greater than 0.05 inch (1949-92) determined on basis of National Oceanic and Atmospheric Administration rainfall gage at Dane County Regional Airport, Madison, Wisconsin. 
to overheating of the sampler. Nine of the 25 flow events with rainfall greater than 0.2 in. were not sampled because they occurred either before the project started or after project sampling was completed but before sediment was removed from the device. Overall, the number of stormwater flow events not sampled due to equipment problems was minimal for rainfall events greater than 0.2 in. Twenty-one of the 25 flow events with rainfall greater than 0.2 in. were sampled for a sampling efficiency of 84 percent during the sampling period.

The settling device was designed to treat up to $3 \mathrm{ft}^{3} / \mathrm{s}$ before flow bypassing begins, and bypassing did occur when flows exceeded $3 \mathrm{ft}^{3} / \mathrm{s}$ (appendix 5). This occurred during seven stormwater flow events, and for five of those events, water-quality samples were collected at the weir wall. The sampled flow events occurred on April 16, May 24, July 27, and August 23 and 24, 2006, and the bypass events that were not sampled were on July 9 and September 12, 2006. On July 9,2006 , flow bypassing occurred for 4 minutes of the flow event; however, this was too short for the bypass sampler to be activated. Stormwater flow events on May 24, July 27, and August 24, 2006, had flow bypassing for almost the entire event, whereas the events on April 16 and August 23, 2006, flow bypassed the settling device for less than 5 percent of the flow duration. Of the eight sampled events with rainfall of 1 in. or greater in depth, five of the stormwater flow events were the sampled events with bypass flows (appendix 5). The difference between the bypass flow events with larger rainfall and those with no flow bypass is the intensity of the rainfall. The peak 15-minute rainfall intensity for the sampled flow events with bypass ranged from 2.0 to $5.5 \mathrm{in} / \mathrm{hr}$, whereas the three larger events without bypass had peak 15-minute intensities ranging from 0.4 to $0.9 \mathrm{in} / \mathrm{hr}$.

Results from 3 of the 26 sampled flow events were not used in any of the calculations in the rest of this report. The dates for these events were May 15 and 24, and July 27, 2006. Data from the event on May 15, 2006, were not complete because the sampler at the device outlet did not collect enough water to process. Not only did the flow events on May 24 and July 27, 2006, have continuous bypass, but the pipes were surcharging to the point where water was coming out of the manhole at the top of the device. The high intensities and large rainfall volumes for these two runoff events produced pipe-full conditions that lasted more than 15 minutes for each event. It was not possible to measure flow accurately under these conditions.

\section{Comparison of Runoff Volumes to Rainfall Volumes}

Another check on the accuracy of the stormwater flow and rainfall measurements was used to calculate the runoff coefficients for each flow event. By dividing the volume of rainfall into the runoff volume, it was possible to determine whether the amount of rainfall produced the expected amount of runoff. The percentage of directly connected impervious area was an important factor in the magnitude of the runoff coefficient, and the percentage of connected impervious area in the study site was about 84 percent. This value assumed that all of the parking lot, roof, and sidewalks were directly connected. For small rainfall depths, almost all of the runoff originated directly from connected areas, but pervious areas and disconnected impervious areas contributed during larger flow events. Runoff coefficients estimated for areas with different amounts of directly connected imperviousness clay soils indicated that the runoff coefficients for the study area probably average about 60 percent (Bochis-Micu and Pitt, 2005).

For most sampled runoff events, the runoff coefficients ranged between about 75 and 85 percent (appendix 5; fig. 10). The average of runoff coefficients for 23 of the sampled events was 84 percent. This is higher than the expected value of about 60 percent. The runoff events on August 23 and 24, 2006, significantly increased the average, with runoff coefficients of about 133 and 216 percent, respectively. The runoff volume for these two events was larger than the recorded rainfall volume. These two runoff events not only occurred during the last month of the study when the inlet draining the adjacent recycling center was clogged (described in more detail in the section on "Methods of Data Collection"), but they also represent relatively large rainfalls. Although the flow measurements were probably accurate for these two events, the overflow from the adjacent recycling center could have easily increased the runoff coefficients above 100 percent. Without these two events, the average runoff coefficient decreases to 75 percent.

Although the 75 percent might be close enough to the suggested value of 60 percent, it is closer to the average runoff coefficient of 70 percent observed for runoff from a hospital site in Green Bay, Wis. (Horwatich and others, 2004). The hospital drainage area had a connected impervious value of 90 percent, and the Bochis-Micu curves estimated a runoff coefficient of about 70 percent for an area with 90 percent connected imperviousness. It might be reasonable to increase the study site connected imperviousness by 6 percent to about 90 percent if the new lawns at the study site are assumed to produce more runoff than the calculations done by BochisMicu. Runoff measurements for lawns 1 to 3 years old and those older than 10 years showed that the runoff volumes from newly developed lawns was significantly greater than runoff from older lawns (Legg and others, 1996). The potential for extra runoff from the 0.29 acre of new lawn at the Water Utility site could be responsible for the somewhat higher than expected average runoff coefficient for the site. By assuming a slightly higher percentage of imperviousness for the site, the flows and rainfall depths measured in this study appear good enough to produce an accurate average runoff coefficient. 


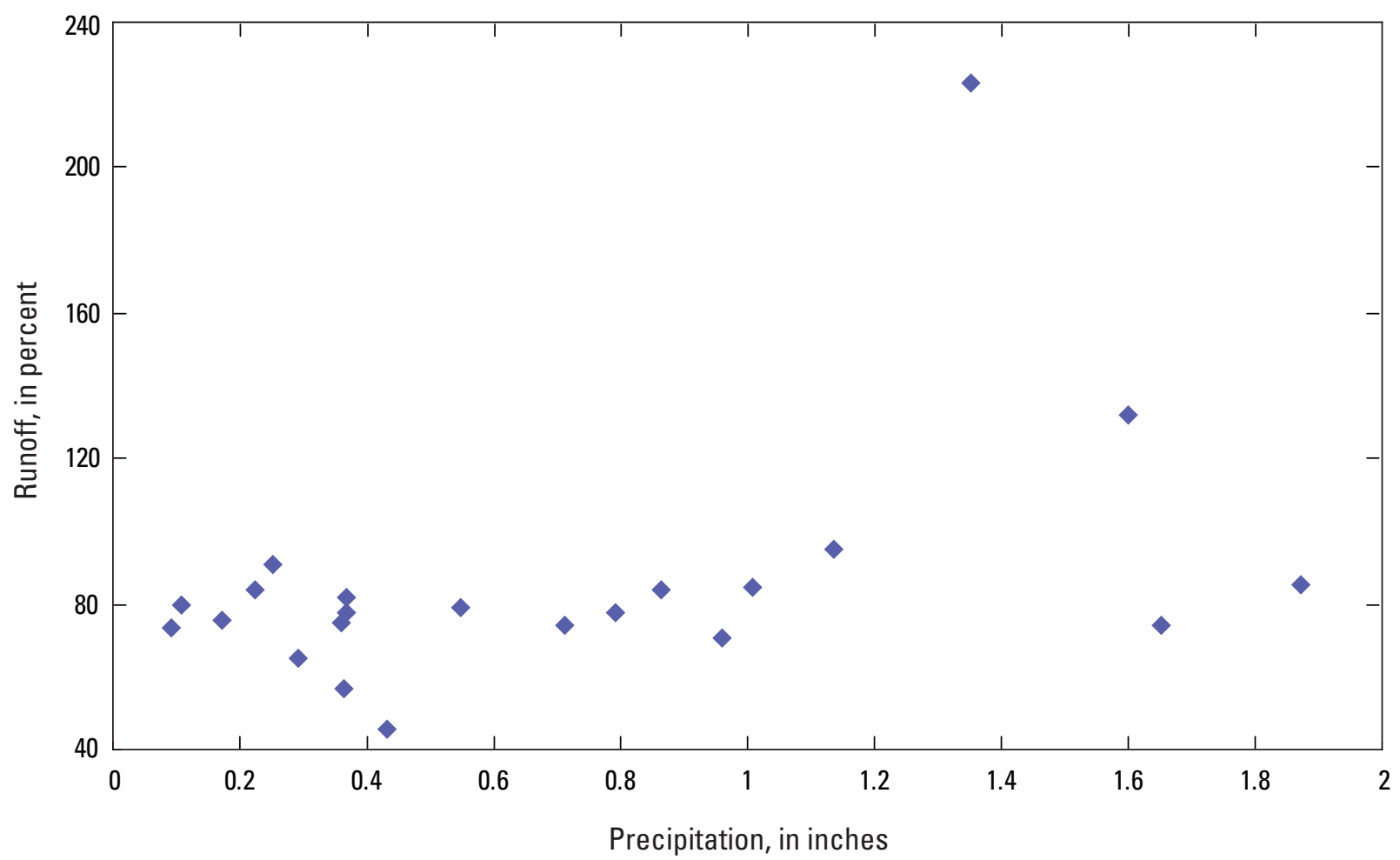

Figure 10. Comparison of percentage of parking lot runoff and rainfall for hydrodynamic-settling device, November 2005-August 2006.

\section{Water-Quality Data for Inlet and Outlet}

Runoff event mean water-quality concentrations were determined for 31 constituents at the inlet and outlet of the hydrodynamic-settling device (appendixes 6-8). Eighteen of the constituents were individual compounds of polycyclic aromatic hydrocarbons (PAHs). Analysis for concentrations of SS, TSS, and TDS were done for all 23 sampled runoff events at both the inlet and outlet of the device. Depending on the amount of water available for analysis, between 17 and 21 of the events were processed for other constituents. Testing for PAHs was limited to seven of the sampled events because the PAH analysis was not performed on samples that were sieved before the splitting process. Bypass samples collected at the weir wall for three runoff events were analyzed for all the constituents except PAHs. Data from the events sampled on May 15 and 24, and July 27, 2006, are not included in the appendixes because of previously discussed problems with the flow monitoring and sample collection.

When a sample was sieved prior to the sample-splitting process, the volatile suspended solids (VSS) and TSS concentrations were not determined for the material left on the sieves. An analysis was done, however, on the material left on the sieve for TP, TZn, and TCu. Because VSS represents the organic material such as leaves and grass clippings in the stormwater, a lot of the VSS material would probably be left on the sieves. Therefore, VSS concentrations are probably underestimated for nine events at the hydrodynamic-settling device inlet, four events at device outlet, and three events at the weir wall. These events were excluded from the appendixes. This leaves 12 runoff events with VSS concentrations for both the inlet and outlet. Total suspended solids concentrations measured in the water were increased to account for the amount on the sieves by using a method (described in the "Methods of Data Collection" section of the report) that is based on the sieve mass and PSD of the material left on the sieve.

All of the water-quality constituents except PAHs, TDS, and DZn had inlet and outlet concentrations greater than detection levels. Dissolved zinc concentrations were less than detection limits for only two runoff events, and the dissolved solids had four events with concentrations less than detection limits. In contrast, the nondetectable compounds composed a substantial proportion of the total PAHs results. Nondetectable compounds were less than detection limits for samples from the device outlet more often than samples from the inlet.

Summary statistics for the individual PAH compounds were not computed because of the large number of runoff events that had individual concentrations that were less than detection limits. To calculate the summary statistics for total PAHs, a method was needed to account for the nondetected concentrations. Methods included using the limit of detections, one-half the limit of detections, and zero. To be consistent 
with other USGS studies, the total PAH concentrations were calculated by using zero (Mahler and others, 2005).

Along with the mean and median, the summary statistics for the constituent concentrations at the inlet, outlet, and bypass included the geometric mean and the mean (table 5). The geometric mean was added because the Shapiro-Wilk statistic test for normality indicated that the concentrations followed a lognormal distribution (Helsel and Hirsch, 1992). Runoff data from many urban sites around the country exhibited similar distributions for event-mean concentrations; these concentrations were either lognormal or could be approximated as log normally distributed (Driscoll and others, 1990). Data sets that were log normally distributed are best described by the geometric mean because it gives less weight to extremes than the mean (Helsel and Hirsch, 1992). The mean concentrations are also important because they are used to calculate the efficiency of stormwater control practices (Strecker and others, 2003).

\section{Water-Quality Data Compared to Other Parking Lots}

The geometric mean concentrations of SS, "adjusted" TSS, TP, dissolved phosphorus (DP), TZn, and TCu were in the range of concentrations observed in runoff from other parking lots in Wisconsin and Michigan (table 6). The concentrations of TZn are on the lower end of the range observed for all the parking lots, and this might reflect the difference between an employee parking lot and the more busy commercial parking lots. The similarity between the concentrations observed in this study and some of the other parking lots indicate that the efficiencies for the hydrodynamic-settling device could be extrapolated to other sites.

Table 5. Summary statistics for selected water-quality constituents in samples collected at inlet, outlet, and bypass of hydrodynamicsettling device, Madison, Wisconsin, November 2005 through August 2006.

[mg/L, milligrams per liter; mg/L, micrograms per liter; \{\}, bypass sample count; —, no data available; PAH, polycyclic aromatic hydrocarbon]

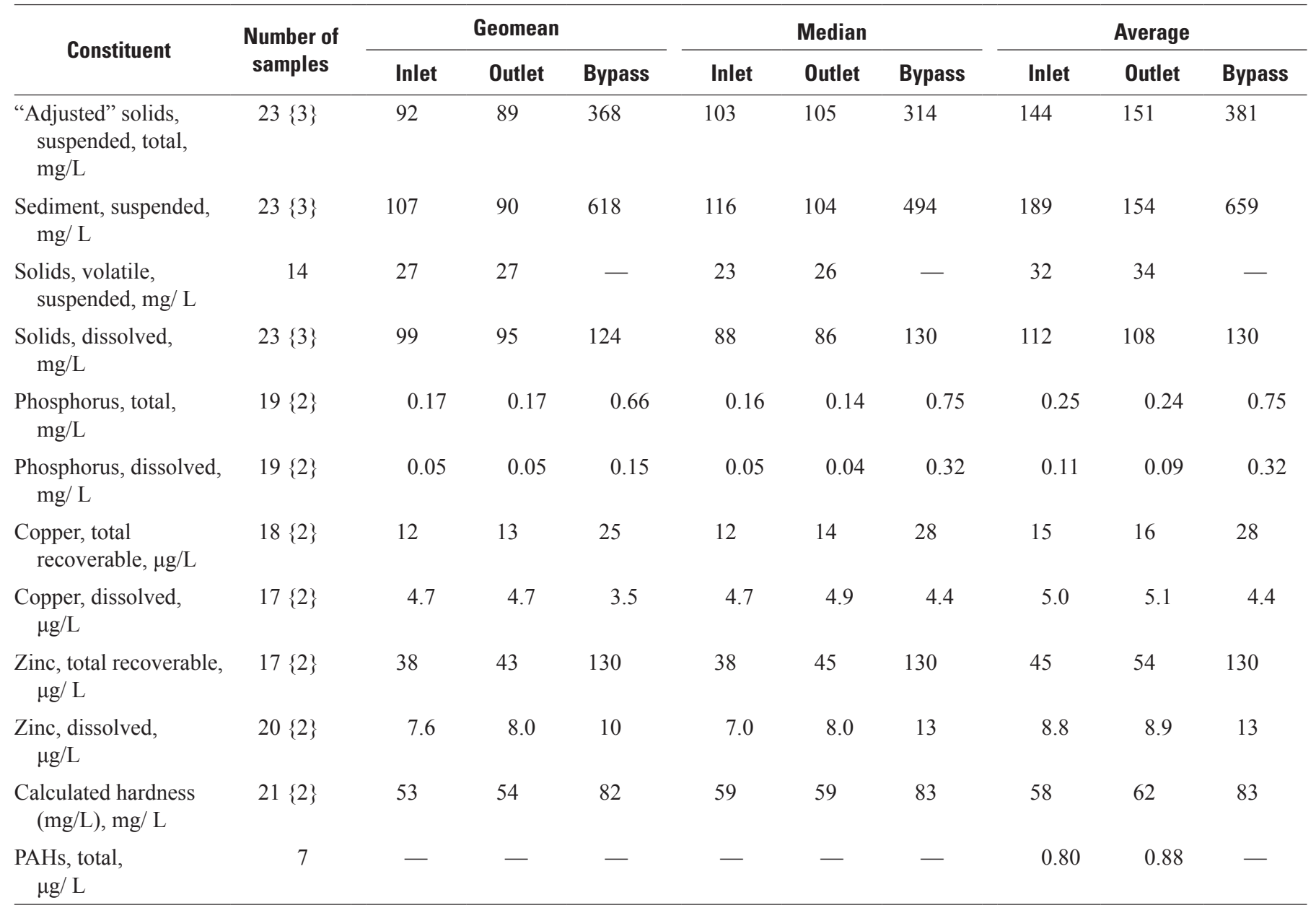




\section{Particle-Size Distributions}

Particle-size distributions are available for 21 runoff events at the inlet and outlet of the hydrodynamic-settling device (appendix 9). The nine particle sizes analyzed for this study included $500,250,125,63,31,16,8,4$, and $2 \mu \mathrm{m}$ in diameter. The PSD at the inlet and outlet varied for each event. For the inlet samples, the portion of sand particles (greater than $63 \mu \mathrm{m}$ in diameter) ranged from 16 to 93 percent, and the outlet samples ranged from 36 to 93 percent. Based on average particle sizes for all the runoff events, the average median particle size for the device inlet was about $50 \mu \mathrm{m}$ in diameter, and the average amount of sand in the samples was about 48 percent (fig. 11, table 7). These averages agree very well with the averages observed at another parking lot monitored in Madison, Wis. (Horwatich and Bannerman, 2010). In the 2010 study, both the average median particle size and level of sand in the samples were slightly less at about 50 and 43 percent, respectively. A wide range in the percentage of sand in each sample was also observed in the runoff from the other parking lot.
Two groups of runoff events were responsible for the extreme values observed in most particle sizes observed at the hydrodynamic-settling device inlet. Compared to the average median particle size and percentage of sand-sized particles for all the runoff events, the events on March 8 and 12, and April 2 and 12, 2006, had the smaller percentages. These four events had an average median particle size of only about $8 \mu \mathrm{m}$ in diameter, and the average percentage of sand in the samples was about 12 percent (fig. 11). At the other extreme, the runoff events on August 17, 23, and 24, 2006 (events 24-26), and water samples had a relatively large percentage of larger particles. The average percentage of sand-sized particles was 70 percent for these three runoff events, and the average median particle size was more than $500 \mu \mathrm{m}$ in diameter. These three events could have had a relatively large amount of large particles in the runoff because of the overflow from the adjacent recycling center. The events occurred during the last month of sampling when the inlet draining the adjacent facility was clogged. Wood chips transported from the recycling facility were observed deposited on the parking lot (figs. 7 and 8) and were observed in the water samples. A few wood chips could greatly increase the percentage of larger particles in the samples.

Table 6. Comparison of geometric mean concentrations from this study with geometric mean and median concentrations observed in other parking lot studies in Wisconsin and Michigan.

[mg/L, milligrams per liter; $\mu \mathrm{g} / \mathrm{L}$, micrograms per liter; med, median; —, no data available]

\begin{tabular}{|c|c|c|c|c|c|c|}
\hline Study & $\begin{array}{c}\text { Total } \\
\text { suspended } \\
\text { solids } \\
\text { (mg/L) }\end{array}$ & $\begin{array}{l}\text { Suspended- } \\
\text { sediment } \\
\text { concentration } \\
\text { (mg/L) }\end{array}$ & $\begin{array}{l}\text { Dissolved } \\
\text { phosphorus } \\
\text { (mg/L) }\end{array}$ & $\begin{array}{c}\text { Total } \\
\text { phosphorus } \\
\text { (mg/L) }\end{array}$ & $\begin{array}{l}\text { Total copper } \\
(\mu \mathrm{g} / \mathrm{L})\end{array}$ & $\begin{array}{l}\text { Total zinc } \\
(\mu \mathrm{g} / \mathrm{L})\end{array}$ \\
\hline $\begin{array}{l}\text { City of Madison Water } \\
\text { Utility, Madison (this study, } \\
\text { (Nov. 2005-August 2006) }\end{array}$ & 92 & 107 & 0.05 & 0.17 & 12 & 38 \\
\hline $\begin{array}{l}\text { Employee parking lot, Madison, } \\
\text { Wis. (Horwatich and } \\
\text { Bannerman, 2010) }\end{array}$ & 15 (med) & 19 & 0.03 & 0.06 & 4 & 20 \\
\hline $\begin{array}{l}\text { St. Mary's Hospital parking lot, } \\
\text { Green Bay, Wis. (Horwatich } \\
\text { and others, 2004) }\end{array}$ & 23 (med) & 31 & 0.02 & 0.06 & - & 50 \\
\hline $\begin{array}{l}\text { City garbage truck parking area, } \\
\text { Milwaukee, Wis. (Corsi and } \\
\text { others, 1999) }\end{array}$ & 232 (med) & - & 0.002 & 0.26 & 32 & 150 \\
\hline $\begin{array}{l}\text { Retail parking lot, Madison, Wis. } \\
\text { (Waschbusch and others, 1999) }\end{array}$ & 50 & - & 0.02 & 0.10 & - & - \\
\hline $\begin{array}{l}\text { Retail parking lot Marquette, } \\
\text { Mich., (Steuer and others, 1997) }\end{array}$ & 110 & - & 0.022 & 0.20 & 22 & 178 \\
\hline $\begin{array}{l}\text { Retail parking lot, Madison, Wis. } \\
\text { (Bannerman and others, 1993) }\end{array}$ & 58 & - & 0.05 & 0.19 & 15 & 178 \\
\hline $\begin{array}{l}\text { Retail parking lot, Milwaukee, } \\
\text { Wis. (Bannerman and } \\
\text { others, 1983) }\end{array}$ & 48 & - & 0.02 & 0.10 & - & 133 \\
\hline
\end{tabular}




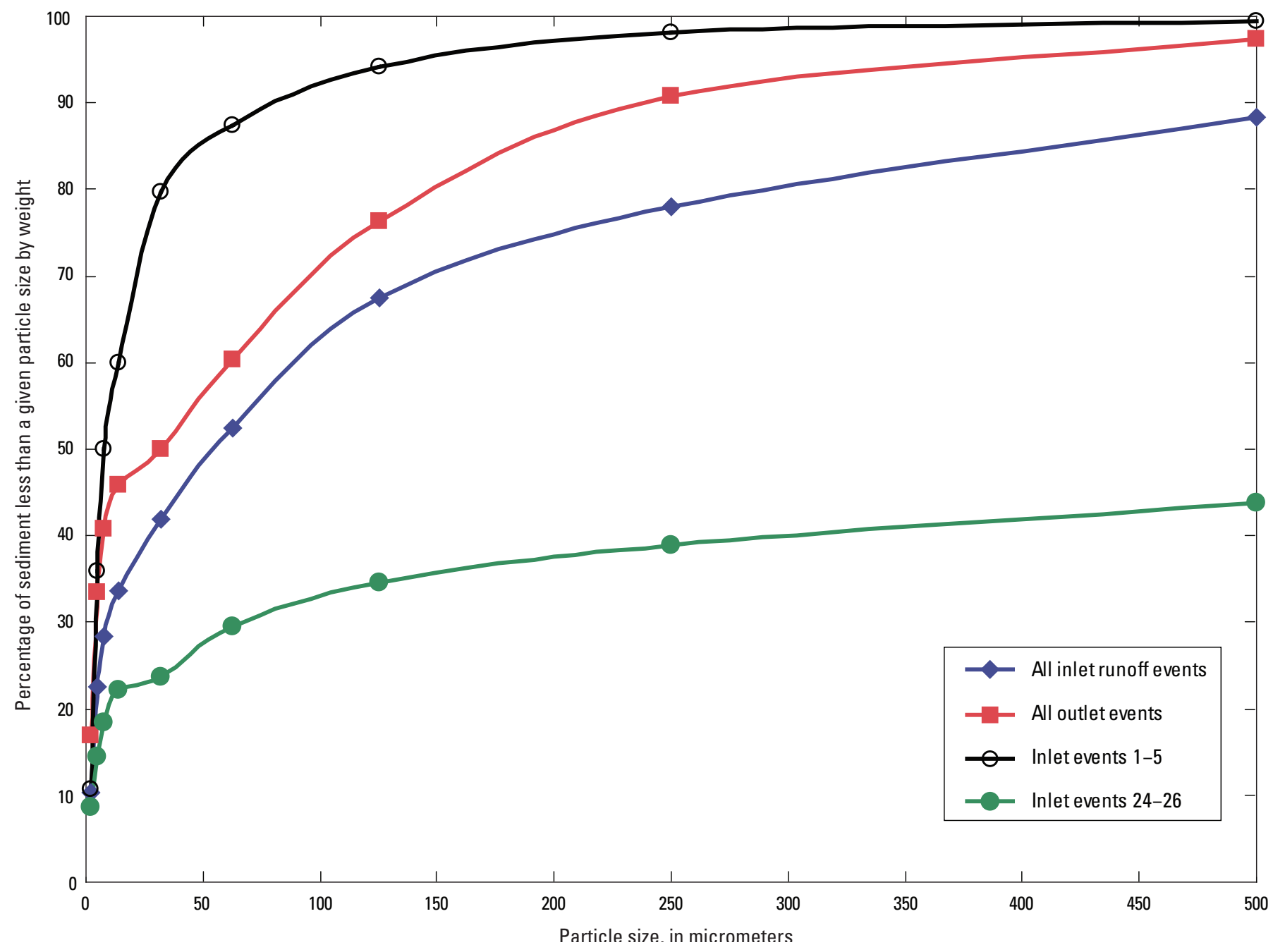

Figure 11. Particle-size distributions determined at inlet and outlet of hydrodynamic-settling device for selected runoff events, November 2005-August 2006.

Table 7. Average particle-size distributions determined at inlet and outlet of hydrodynamic-settling device for selected runoff events, Madison, Wisconsin, November 2005-August 2006.

[All values are in percent less than by mass; $\mu \mathrm{m}$, micrometers in diameter]

\begin{tabular}{lccccccccc}
\hline \multicolumn{1}{c}{ Particle size $(\boldsymbol{\mu m})$} & $\mathbf{5 0 0}$ & $\mathbf{2 5 0}$ & $\mathbf{1 2 5}$ & $\mathbf{6 3}$ & $\mathbf{3 1}$ & $\mathbf{1 6}$ & $\mathbf{8}$ & $\mathbf{4}$ & $\mathbf{2}$ \\
\hline Device inlet - all runoff events & 88 & 78 & 67 & 52 & 42 & 34 & 28 & 23 & 10 \\
Device outlet - all runoff events & 97 & 91 & 77 & 59 & 47 & 38 & 31 & 25 & 12 \\
First four device inlet runoff events & 98 & 95 & 89 & 83 & 76 & 59 & 51 & 39 & 15 \\
Last three device inlet runoff events & 44 & 39 & 35 & 29 & 24 & 22 & 18 & 14 & 9 \\
\hline
\end{tabular}


Water samples collected at the outlet of the hydrodynamic-settling device had a larger percentage of fine particles than inlet samples (fig. 11, table 7). From the inlet to the outlet, the average median particle size decreased from 52 to 44 $\mu \mathrm{m}$ in diameter. The average percentage of particles less than $63 \mu \mathrm{m}$ in diameter increased from 52 to 59 percent. Some of the largest changes in the percentage of particles sizes occurred in the 16 and $250 \mu \mathrm{m}$ in diameter. Average percentages of particles less than $16 \mu \mathrm{m}$ in diameter increased from about 34 to 38 percent, and the average percentage of particles greater than $250 \mu \mathrm{m}$ in diameter decreased from about 22 to 9 percent (fig. 11). This increase in finer particle sizes coupled with the decrease in larger particle sizes indicates that the settling device was preferentially trapping the larger particles.

In previous studies of stormwater control practices, the PSD was shown to have some effect on the efficiency of the device (Waschbusch, 1999; Horwatich and others, 2004). Based on average PSD at the inlet, a device would need to control all the particles greater than about $250 \mu \mathrm{m}$ in diameter to achieve a 20-percent reduction in TSS. To achieve the performance standards in NR151, particles greater than $90 \mu \mathrm{m}$ in diameter and about $3 \mu \mathrm{m}$ in diameter would need to be controlled to achieve the 40-percent and 80-percent reduction in TSS reduction, respectively. With all the variability in the PSD, the efficiency of the settling device would be expected to vary somewhat among runoff events.

\section{Efficiency Calculations}

Two methods typically used by investigators to determine the removal efficiency of constituents by a stormwater control practice are the efficiency ratio and summation of loads (SOL) (National Cooperative Highway Research Program, 2006). The efficiency ratio uses runoff event mean concentration of contaminants detected in samples collected during the study. The SOL is used to evaluate the treatment efficiency on a percentage basis by comparing the sum of the influent and effluent loads (the product of multiplying the constituent concentration by the runoff volume) for all monitored events.

Each method uses data from the inlet and outlet to produce a single number that is designed to represent removal efficiency of the device. Unfortunately, these methods are not designed to evaluate the statistical differences in the data, so there is insufficient information generated by the methods to determine whether the differences in water-quality measurements for samples from the inlet and outlet are significant. These efficiency calculations can be supplemented with a statistical test that indicates whether the medians for nonparametric concentrations are statistically significant (Helsel and Hirsch, 1992).
A paired statistical test was used to determine whether the constituent concentrations at the inlet were greater than those at the outlet. A paired statistical test was considered valid for this data set because concentrations at the inlet and outlet were paired for each runoff event. Most of the constituents were log normally distributed; therefore, the nonparametric one-sided Wilcoxon signed-rank test was applied (Helsel and Hirsch, 1992). A test for significance and efficiency ratios calculations was not done for calcium and magnesium because the concentrations of these two constituents were only used in the calculation of hardness. In addition, a test for PAHs was not done because only seven samples were collected, and results from these samples were mostly nondetections.

Inlet and outlet concentrations were significantly different at the 95 -confidence level for 4 of the 28 constituents analyzed during this study. Concentrations in runoff at the settling device inlet were larger than concentrations at the device outlet for SS and DP, but the concentrations for VSS and TZn were significantly larger at the device outlet than at the inlet. At the 84-percent confidence level, the "adjusted" TSS inlet concentrations were larger than the outlet concentrations. Because VSS was not analyzed for the particulate matter trapped on the sieves during sample processing, the number of runoff events available for the efficiency calculation was relatively small. For this reason, VSS efficiencies are not reported for this study even though there is a significant difference between the inlet and outlet concentrations. Concentrations of TDS, TP, TCu, DCu, and DZn were not significantly different for the inlet and outlet samples, so efficiencies were not determined for these constituents.

\section{Efficiency Ratio}

The efficiency ratio comparison evaluates treatment efficiencies on a percentage basis by dividing the constituent concentration at the outflow of the hydrodynamic-settling device by the concentration at the inflow of the device and multiplying the quotient by 100 . This method of calculating efficiencies of a device weights all runoff events equally. For example, a large volume of flow with large constituent concentrations has the same weight as a small volume of flow with small constituent concentrations. The device outlet concentration could be affected by the water stored in the device between events; however, sufficient runoff volume exchange occurred for the runoff events to minimize the effect of this stored volume. As discussed previously, the volume exchanges at least 8 times for most events, and the volume is replaced at least 16 times for more than one-half of the runoff events. Efficiency ratio calculations were done for both the device and 
the stormwater control system. The efficiency ratio calculation for the settling device is represented by the following equation (U.S. Environmental Protection Agency, 1999):

$$
\text { Device efficiency ratio }=\left[1-\frac{(\text { average concentration at sampling point } C)}{(\text { average concentration at sampling point } B)}\right] * 100,
$$

where

sampling point $B$ is the device inlet, and

sampling point $C$ is the device outlet.

Because three of the sampled runoff events had flow over the bypass weir, the efficiency ratio was also calculated for the bypass system. An efficiency ratio for the bypass system of the device accounted for the constituent concentrations sampled at the weir wall. This usually results in a smaller efficiency ratio than determined for the settling device, but it is a more realistic assessment of how the device protects receiving waters. A flow-weighted average concentration was used to calculate the system efficiency because the bypass concentrations only represented three runoff events. Flow-weighted average concentrations were determined for device inlet, device outlet, and system outlet by summing the total loads then dividing by their respective total volumes. The calculation for the stormwater control system efficiency ratio is represented by the following equation:

System efficiency ratio $=\left[\frac{(\text { weighted average concentration at sampling point } B-\text { weighted average concentration at point } C)}{(\text { weighted average concentration at sampling point } B+\text { weighted average concentration at point } E)}\right] * 100$,

where

point $B$ is the device inlet;

point $C$ is the device outlet; and

point $E$ is the bypassing over the weir wall.

Both settling device and control system efficiency ratios were calculated for concentrations of SS, "adjusted" TSS, DP, and TZn (table 8). The efficiency ratio for SS was reduced by 19 percent and the "adjusted" TSS increase by 5 percent. An increase of "adjusted" TSS might be due to the average percentage of sand in the samples at about 50 percent (table 7), the difference in the SS efficiency ratio and "adjusted" TSS efficiency ratio could be that the TSS analysis does not applying very well to water samples containing a significant amount of larger particles with a high specific gravity (Gray and others, 2000; de Ridder and others, 2002; Clark and Siu, 2008; Roesner and others, 2007; Selbig and Bannerman, 2007; Clark and others, 2008; Kayhanian and others, 2008). By taking an aliquot from a sample, the TSS analysis can bias against larger particles that settle rapidly before the aliquot is taken. In contrast, the analytical method for concentration of SS uses the entire sample volume; therefore, the true concentration of SS is more representative by this method.

A positive efficiency ratio of 23 percent was observed for TZn at another hydrodynamic-settling monitored in Milwaukee, Wis. (Horwatich and others, 2010). Part of the reason that the efficiency ratio was increased at the outlet in this study might be the average concentration at the device inlet was about five times smaller than observed at the Milwaukee site. The settling device efficiency ratio for TDS was similar to the 28 percent observed for the site in Milwaukee. Because the control system efficiency ratios were similar to the device efficiency ratios for all the constituents, the three bypass events appear to have little effect on the benefits of the device. It was not clear why the concentration of DZn increased at the outlet, but anoxic conditions from the stagnant water at the bottom of the device could have caused oxidation reduction of DZn-complexes.

Table 8. Summary of flow-weighted average concentrations, control system efficiency ratios, and device efficiency ratios for the hydrodynamic-settling device in Madison, Wisconsin, November 2005-August 2006.

[mg/L, milligrams; $\mu \mathrm{g} / \mathrm{L}$, micrograms per liter]

\begin{tabular}{|c|c|c|c|c|c|c|}
\hline Constituent & $\begin{array}{c}\text { Number of } \\
\text { samples } \\
\text { device/control }\end{array}$ & $\begin{array}{l}\text { Flow-weighted } \\
\text { average inlet } \\
\text { concentration }\end{array}$ & $\begin{array}{l}\text { Flow-weighted } \\
\text { average outlet } \\
\text { concentration }\end{array}$ & $\begin{array}{l}\text { Flow-weighted } \\
\text { average bypass } \\
\text { concentration }\end{array}$ & $\begin{array}{l}\text { Device } \\
\text { efficiency } \\
\text { ratio, in } \\
\text { percent }\end{array}$ & $\begin{array}{l}\text { Control system } \\
\text { efficiency } \\
\text { ratio, in } \\
\text { percent }\end{array}$ \\
\hline $\begin{array}{l}\text { Suspended-sediment } \\
\text { concentration }(\mathrm{mg} / \mathrm{L})\end{array}$ & $23 / 3$ & 189 & 154 & 659 & 19 & 18 \\
\hline Phosphorus, dissolved (mg/L) & $19 / 2$ & 0.106 & 0.090 & 0.319 & 15 & 18 \\
\hline Zinc, total recoverable $(\mu \mathrm{g} / \mathrm{L})$ & $19 / 2$ & 45.1 & 53.6 & 127 & -19 & -5 \\
\hline
\end{tabular}




\section{Sum of Loads}

The SOL is used to evaluate the treatment efficiency on a percentage basis by comparing the sum of the influent and effluent loads (the product of multiplying the constituent concentration by the runoff volume for an event) for sampled events. The SOL method of calculating efficiencies is weighted by the runoff volume of each event. This means that a small number of events with larger runoff volumes can have more effect on the SOL than a large number of events with small runoff volumes. The settling device inlet runoff volumes were used to calculate both the inlet and outlet loads because the inlet volumes were calibrated and considered more accurate than the outlet volumes. As discussed for the efficiency ratio calculations, the water stored in the device between runoff events was considered too small to have a significant effect on the SOL.
The equation calculating the device percentage of load reduction is:

$$
\text { Summation of loads }=\left[1-\left(\frac{\text { sum of outlet loads }}{\text { sum of inlet load }}\right)\right] \text {. }
$$

The SOL for the settling device does not account for the load that bypassed the device without being treated. By including the load that bypassed in the efficiency calculation, a more realistic assessment of the device's benefits to the receiving waters is possible. Calculating the SOL for the whole system will usually lower the percentage of load reduction values (Waschbusch, 1999).

The equation calculating the control system percentage of load reduction using the sum of the loads is:

$$
\text { Summation of loads for the system }=100 *\left[\frac{(\text { sum of the device inlet load }- \text { sum of the device outlet load })}{(\text { sum of the device inlet load }+ \text { sum of the bypass load })}\right] \text {, }
$$

where

sum of inlet load is the sum of (runoff volume at point

$\mathrm{B} *$ concentration at point $\mathrm{B})$;

sum of outlet load is the sum of (runoff volume at point

$\mathrm{C}^{*}$ concentration at point $\mathrm{C}$ ); and

sum of bypass load $=$ the sum of $[($ volume at point $D-$ runoff volume at point $B)] *$ concentration at point $E$

where

point $B$ is the device inlet;

point $C$ is the device outlet; and

point $\mathrm{E}$ is the bypassing over the weir.

As for the efficiency ratios, the SOLs were only calculated for constituents with significantly different inlet and outlet runoff event mean concentrations. The SOLs for the settling device and the bypass system were calculated for "adjusted" TSS, SS, DP, and TZn (table 9, appendix 10 and 11). Similar to the results for the efficiency ratio, the percentage of load reduction for SS is larger than the "adjusted" TSS As discussed before, the smaller "adjusted" TSS load is probably due to the loss of some of the larger particles during the TSS analysis. As expected, the percentages of load reductions for the bypass system were slightly less than the reduction for the settling device. The similarity between the reductions for the settling device and bypass system indicates that the amount of bypass flow was insufficient to reduce the benefit of the device. The bypass loads for both "adjusted" TSS and SS were less than 15 percent of the total inlet load, and the bypass load for DP was only 4 percent of the inlet load.
The percentage of bypass system load reduction for "adjusted " TSS of 9 percent is lower than the reduction observed in evaluations of other hydrodynamic-settling devices. Monitoring of settling devices in a Madison urban stormwater study (Waschbusch, 1999) and in a Milwaukee highway runoff study (Horwatich and others, 2010) indicated TSS load reductions of 21 and 25 percent, respectively. The TZn load reduction for these two other studies was about 17 percent compared to an increase in load observed for the study described in this report. The only obvious difference in the runoff characteristics between the sites in this study and the other two studies was that the TZn runoff event mean concentrations were much higher at the device inlet for the other two studies. The bypass system load reductions for DP measured at the two Madison sites were very similar at 17 percent.

If the two runoff events on August 23 and 24, 2006, had not been sampled, the percentages of load reduction for SS and "adjusted" TSS would have been significantly less. The SS load at the inlet without these two event is $469 \mathrm{lb}$ and at the outlet is $396 \mathrm{lb}$ and the for "adjusted" TSS load inlet is $368 \mathrm{lb}$ and outlet is $383 \mathrm{lb}$. Removing these two events from the SOL 
Table 9. Summary of constituent loads and percentage efficiency for hydrodynamic-settling device in Madison, Wisconsin, November 2005-August 2006.

[SOL, summation of loads; lb, pounds; $\%$, percent]

\begin{tabular}{lccccc}
\hline \multicolumn{1}{c}{ Constituent } & Inlet SOL (lb) & Outlet SOL (lb) & Bypass SOL (lb) & Device SOL (\%) & System SOL (\%) \\
\hline Suspended sediment & 1,590 & 979 & 228 & 38 & 39 \\
Suspended solids, total “adjusted" & 1,090 & 993 & 134 & 9 & 12 \\
Phosphorus, dissolved & 1.15 & 0.930 & 0.049 & 19 & 22 \\
Zinc, total recoverable & 0.211 & 0.239 & 0.0193 & -13 & -4 \\
\hline
\end{tabular}

calculations lessens the settling-device percentages of load reduction to 16 percent for SS and to -4 percent for "adjusted" TSS (appendix 10), which is a notable change in load reduction when comparing it to using all 23 runoff events in the SOL calculations. Similar reductions would be expected for DP, but it was not measured for the runoff event on August 24.

The August 23 and 24 runoff events have a large effect on SOL because they not only represented about 70 percent of the total inlet load but they also experienced relatively large reductions in SS and "adjusted" TSS. For SS the device reductions on August 23 and 24 were 38 and 54 percent, respectively, and the "adjusted" TSS reductions were 0 and 26 percent, respectively (appendix 10). Because these two runoff events had additional runoff from an adjacent city recycling facility, an unusually large amount of runoff and particulate matter was delivered to the settling device. Although these two events should be included in the efficiency calculations, the effect of these runoff events does indicate that the performance of the device might be somewhat less for similar sites not affected by additional sources of particulate matter, such as recycling facilities and soil erosion.

The effect of the August 23 and 24 runoff events might also explain the large differences between the efficiency ratios and percentage of load reductions for SS and "adjusted" TSS (tables 8 and 9). When the two events are removed from the SOL calculation, the resulting percentage of load reductions for SS and "adjusted" TSS are very similar to the efficiency ratios. The percentage reduction in load is 16 percent for SS, which is very close to the efficiency ratio of 19 percent. Differences in the two types of efficiency calculations are relatively small for DP because the August 24 runoff event was not included in either calculation. The effect of the two August runoff events demonstrates potential differences between the two methods of determining efficiencies of a settling device but also puts emphasis on evaluating the uniqueness of any runoff event when calculating the SOL.

\section{Sum of Loads by Particle Size}

Calculating the SOLs by particle size determines how the PSD might affect the efficiency of the hydrodynamic-settling device. The manufacturer's claim for the performance of the device is based on a given PSD (U.S. Environmental Protection Agency, 2007). For runoff at $15^{\circ} \mathrm{C}$, the manufacturer claims the device will remove more than 80 percent of the settleable solids with a PSD similar to the Maine Department of Transportation road sand and a specific gravity of 2.65. Almost all the particles in Maine Department of Transportation road sand are in the sand-size fraction or greater than $63 \mu \mathrm{m}$ in diameter (table 10). The median particle size for the Maine Department of Transportation is $700 \mu \mathrm{m}$ in diameter. To achieve an 80-percent removal with the Maine Department of Transportation PSD, the device would have to be only efficient at removing particles greater than $250 \mu \mathrm{m}$ in diameter.

The settling device inlet and outlet SOL by particle size was determined by multiplying the concentration of SS for each particle size times the inlet volume. Because the particlesize analysis captures all the particles at each size, the analysis is a representation of SS and not TSS. The percentage of SS load reduction was determined for each particle size for both the settling device and bypass system (table 11). Most of the reduction in SS occurred for particles greater than $250 \mu \mathrm{m}$ in diameter. Because about 45 percent of the particles were greater than $250 \mu \mathrm{m}$ in diameter, an estimate of the percentage of load reduction for SS could be made by multiplying the 90-percent reduction times 45 percent. The result of this calculation is 40 percent, and this is very similar to the SS load reduction determined for the settling device (table 8). These results support the manufacturer's claim of achieving a high percentage reduction for the larger particles.

\section{Factors That Affect Variability in Efficiency}

Suspended-sediment settling-device efficiencies for individual runoff events (fig. 12) varied from as low as -47 percent to as high as 70 percent. Two potential sources of variability between runoff events are the factors affecting the settling velocity of the particulate matter and any bias caused by the sampling techniques. Variability due to the settling velocity of the particles is more easily evaluated with the available data, but literature is available to support some speculation about the importance of sampling bias. Because sedimentation is the primary mechanism for the settling device to remove suspended particulate matter from the water column, the 
Table 10. Particle-size distribution for Maine Department of Transportation road sand (U.S. Environmental Protection Agency, 2007).

$[>$, greater than $]$

\begin{tabular}{ccccccccc}
\hline $\begin{array}{c}\text { Particle size } \\
\text { (micrometers) }\end{array}$ & $\mathbf{> 1 0 , 0 0 0}$ & $\mathbf{2 , 0 0 0}$ & $\mathbf{1 , 0 0 0}$ & $\mathbf{5 0 0}$ & $\mathbf{3 2 0}$ & $\mathbf{2 5 0}$ & $\mathbf{1 2 5}$ & $\mathbf{6 3}$ \\
\hline Percent less than & 98 & 78 & 58 & 43 & 30 & 15 & 8 & 5 \\
\hline
\end{tabular}

Table 11. Sum of loads and percentage of suspended-sediment load reduction by particle size for hydrodynamic-settling device and bypass system in Madison, Wisconsin, November 2005-August 2006.

[SOL, summation of loads; $1 \mathrm{~b}$, pounds; \%, percent; >, greater than]

\begin{tabular}{ccccccc}
\hline $\begin{array}{c}\text { Particle size } \\
\text { (micrometers) }\end{array}$ & $\begin{array}{c}\text { Device inlet SOL } \\
\text { (lb) }\end{array}$ & $\begin{array}{c}\text { Device outlet SOL } \\
(\mathbf{l b})\end{array}$ & $\begin{array}{c}\text { Bypass SOL } \\
(\mathbf{l b})\end{array}$ & $\begin{array}{c}\text { Inlet load } \\
\text { percentage of } \\
\text { total load }\end{array}$ & $\begin{array}{c}\text { Device SOL } \\
(\%)\end{array}$ & $\begin{array}{c}\text { Bypass system } \\
\text { SOL } \\
(\%)\end{array}$ \\
\hline$>500$ & 242 & 15 & 32 & 17 & 94 & 83 \\
$500-250$ & 406 & 41 & 22 & 28 & 90 & 85 \\
$250-125$ & 129 & 121 & 20 & 9 & 6 & 5 \\
$125-63$ & 114 & 133 & 22 & 8 & -17 & -14 \\
$63-32$ & 110 & 112 & 18 & 7 & -2 & -1 \\
$32-14$ & 448 & 473 & 76 & 31 & -6 & -5 \\
\hline
\end{tabular}

most commonly used equations for estimating the degree of sedimentation depend on knowing the settling velocity of the particles (Minton, 2005; Strecker and others, 2005; Field and others, 2006). Settling velocity is affected by particle size and shape, specific gravity of the particles, and water temperature. Peak-flow through rate and the degree of turbulence during a runoff event are two other factors frequently found in equations used to design sedimentation devices.

Using the ratio of VSS to "adjusted" TSS as an indicator of specific gravity of the particles, one source of variability is certainly the wide range in percentage of VSS. The range in percentage of VSS for the inlet runoff events was 17 to 67 percent with an average of 41 percent for 13 events (appendix 6). The average concentrations for VSS of $32 \mathrm{mg} / \mathrm{L}$ and TSS "adjusted" $98 \mathrm{mg} / \mathrm{L}$ for a ratio of 33 percent for 13 events (appendix 6). These particles probably have their origins in dead vegetative material, and many of them would be captured in the sand-sized fractions. The specific gravities for the particulate matter in most stormwater samples can range from 1.5 to 2.5 (Burton and Pitt, 2002). Variability in the specific gravities may be affected by the organic content of the particles (Kayhanian and others, 2008). Specific gravities of organic detritus found in stormwater samples have been reported to range from 1.1 to $1.8 \mathrm{~g} / \mathrm{cm}^{3}$ (Christina and others, 2002; Kayhanian and others, 2008). Because the particles associated with the VSS concentration would be less likely to settle to the bottom of the device, the removal efficiency of the device could be affected by the percentage of VSS in the runoff.

Results from this study show a high variability in removal efficiencies with peak flows that are less than the design flow (fig. 12). The efficiencies tended to be all positive at the lowest peak flows. Four runoff events with peak flows between about 1.8 and $2.7 \mathrm{ft}^{3} / \mathrm{s}$ had negative efficiencies. Testing of two other hydrodynamic-settling devices in Wisconsin also showed a high variability in concentrations of SS and TSS removal efficiencies for peak flows that were less than the design flow (Waschbusch, 1999; Horwatich and other, 2010). Three of the events (April 16 and August 23 and 24, 2006) in this study had bypass system peak flows that were greater than the design flow, but the flow splitter prevented the flow from exceeding the design flow at the device inlet. Contrary to results from the other four runoff events with high peak flows, these three events had positive efficiencies. Their efficiencies were enhanced by the high percentage of particles greater than $125 \mu \mathrm{m}$ in diameter (appendix 9). For the two other hydrodynamic-settling devices monitored in Wisconsin, the removal efficiencies tended to be low or negative when their peak flows exceeded the design flows. Changes in peak flows by themselves do not seem to be good indicators of changes in efficiencies except a when a negative efficiency might be 


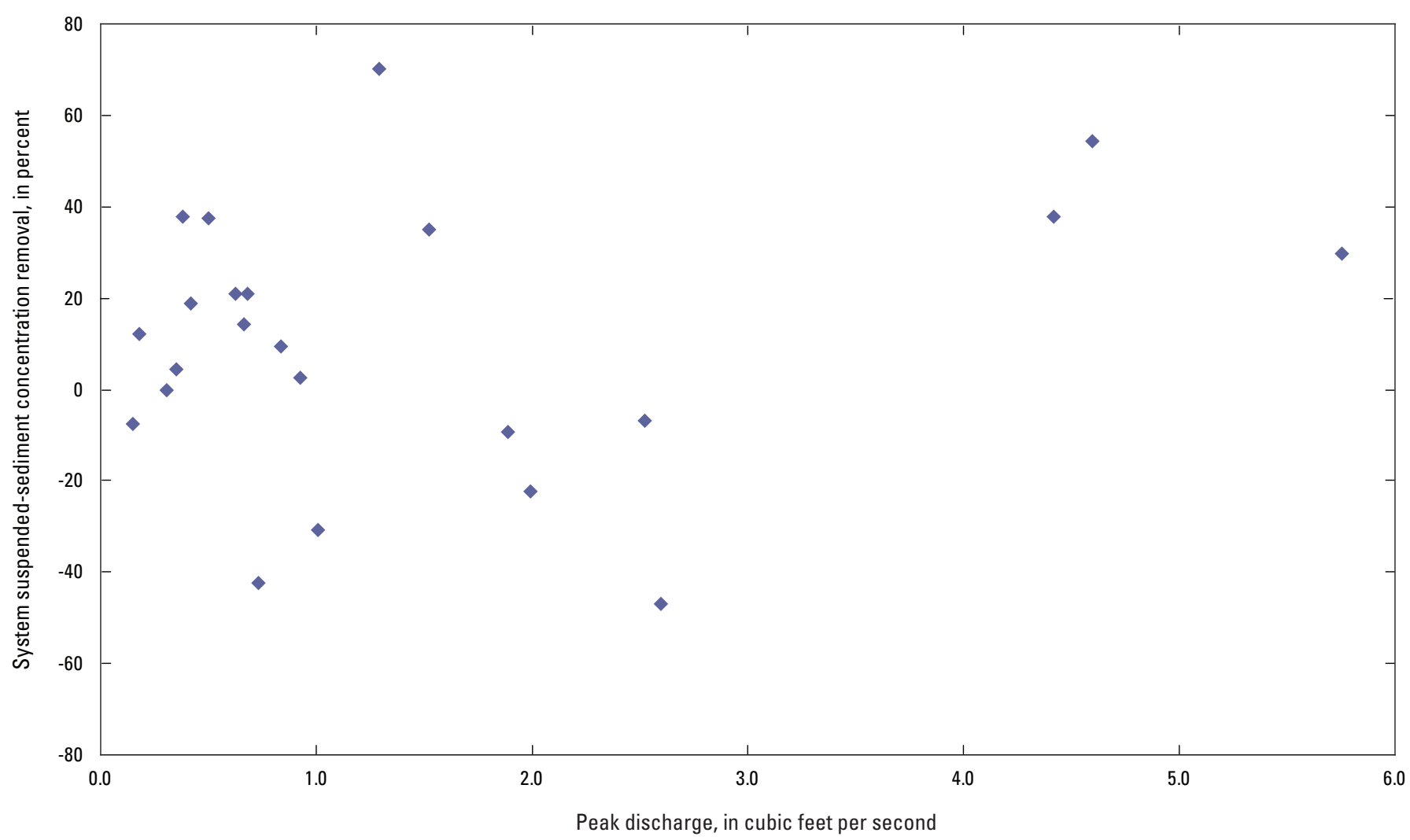

Figure 12. Removal efficiency of suspended solids and total solids as a function of peak flow for hydrodynamic-settling device system, November 2005-August 2006.

expected as peak flows approach or exceed the design flow at the inlet.

Although the variations in the removal efficiency of a wet pond (House and others, 1993) was shown to be related to all particle sizes (Greb and Bannerman, 1997), the results from the study described herein indicate that the only relationship between influent particle size and removal efficiency might be for particle sizes greater than $125 \mu \mathrm{m}$ in diameter. The SS efficiencies tend to be greater if the percentage of $125 \mu \mathrm{m}$ in diameter particles is more than about 45 percent (fig. 13). Above 45 percent, there is a trend of increasing SS efficiency with increasing percentage of $125 \mu \mathrm{m}$ in diameter particles. Influent particle size does not seem to significantly affect the variability in the SS efficiency for particles less than $125 \mu \mathrm{m}$ in diameter. Particle size appears to have a somewhat stronger effect on SS efficiencies than peak flow, but neither one by themselves have a strong enough effect to explain all the variability in the SS efficiencies.

The other source of variability to consider is potential bias due to the way the samples were collected. A number of authors have reported potential problems with trying to collect a representative sample with an automatic sampler, especially if there are large amounts of sand-sized particles in the water column (Clark and others, 2008; DeGroot and others, 2009; Fowler and others, 2009). When the sampler is not able to intake the proper proportion of large particles, the concentration of SS can be underestimated (Clarke and others, 2008). Conversely, the concentration of SS might be overestimated if the larger particles are stratified in the pipe, and the sampling tube intake is located near the bottom of the pipe (DeGroot and others, 2009; Selbig and Bannerman, 2010), as in this study. One possible indicator of stratification is a relatively large percentage of larger particles in a sample. Several events had greater than 50 percent of the particles in the sand size fraction for the inlet samples (appendix 9). These events are also characterized by relatively large flows and SS concentrations. If the inlet SS concentrations for these events were positively biased due to stratification, the load reductions would be overestimated for the events. Since these events also represent a large percentage of the total inlet SS load for the study period, the SOL for the SS could also be an overestimate. The SOL for other particulate constituents, such as TSS and TP, would be less affected, because the laboratory procedures for retrieving an aliquot from the sample bottle tends to reduce the percentage of large particles in the sub-sample to be analyzed (Selbig and Bannerman, 2011).

\section{Accuracy of Efficiency Calculations}

One way of checking the accuracy of the measured SS loads at the inlet and outlet of a settling device is to weigh 
the sediment that is retained in the sediment-storage sump. The weight of the sediment retained in the device should be reasonably close to the calculated reduction in SS loads. To remove as much as possible from the sediment trapped in the storage sump, the sediment was removed from the sump on three different dates. On September 15, 2006, the City of
Madison filled a vacuum truck to capacity with water and sediment from the settling device. The material was transported to the USGS Water Science Center in Madison where the particulates in the slurry were allowed to settle while still in the truck. The truck drained the water from the slurry into a city storm sewer. The remaining slurry was dumped into a

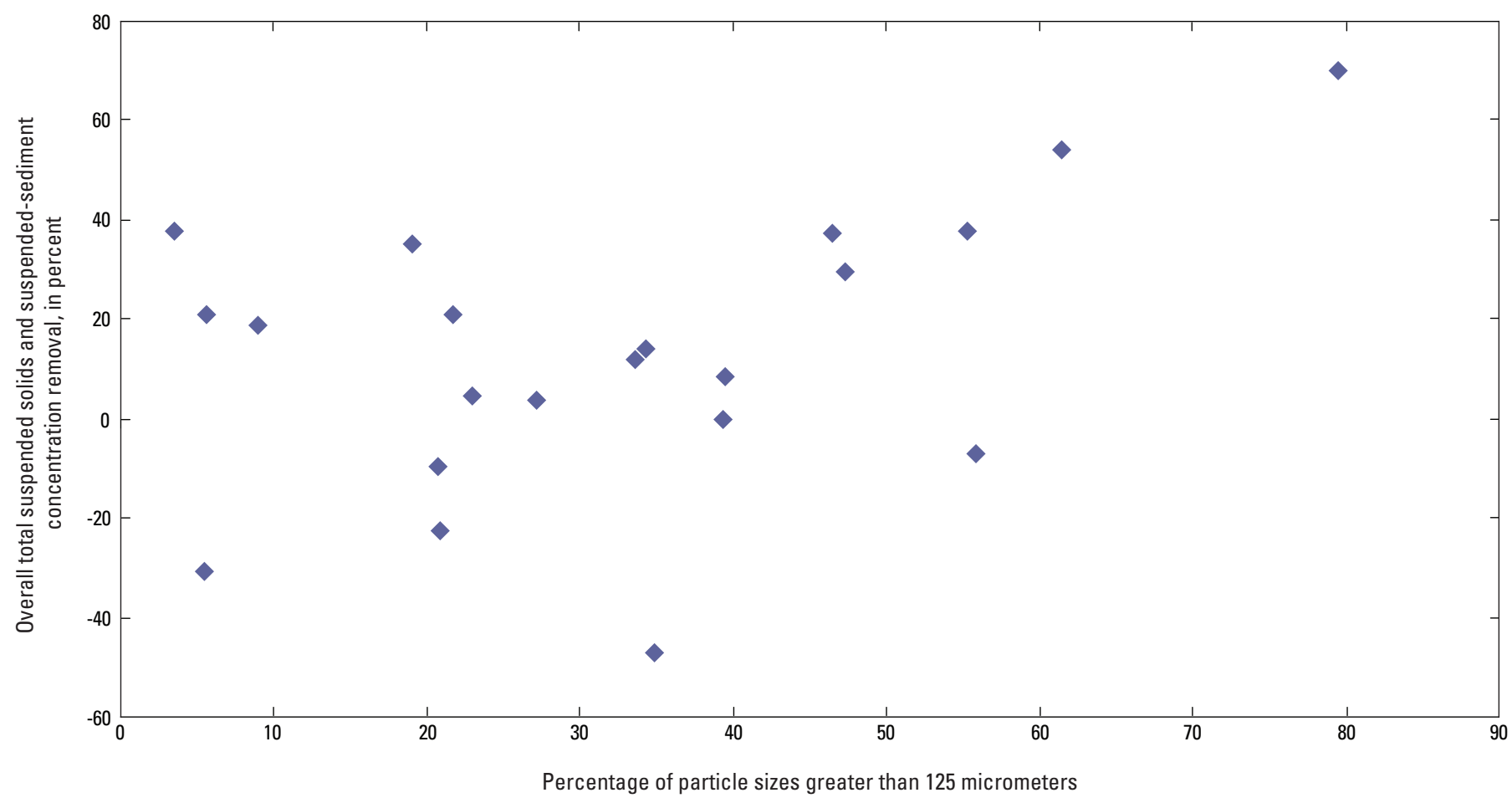

Figure 13. Variability in suspended-solids removal efficiency relative to percentage of particle sizes greater than 125 micrometers for hydrodynamic-settling device, November 2005-August 2006.

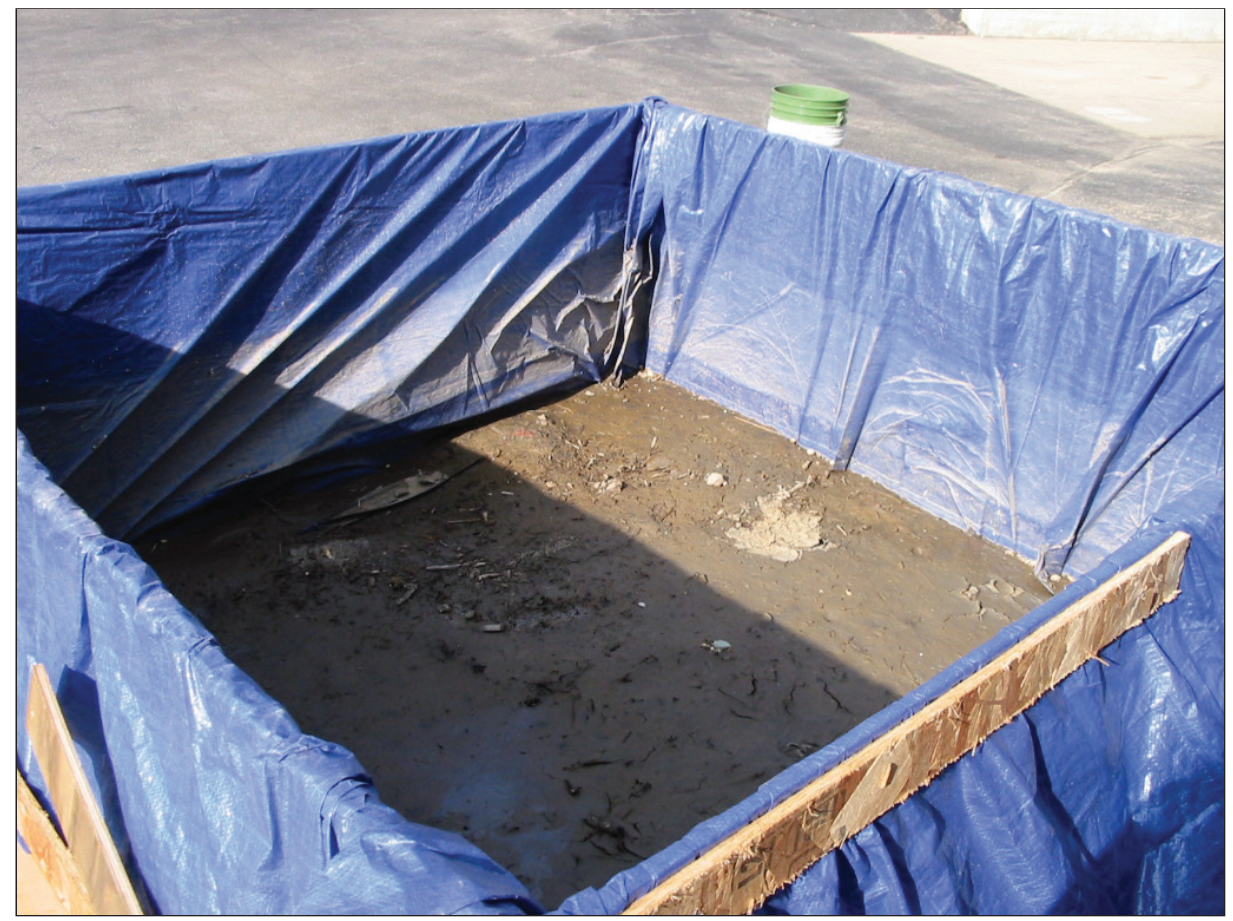

Figure 14. Slurry tank for drying material vacuumed from bottom of hydrodynamic-settling device. 
tank (tank 1) consisting of a plastic tarp held up by a wooden frame (fig. 14).

More sediment and water were removed from the treatment chamber on September 20 and 21, 2006, using a 2-in. trash pump and a 3-in. trash pump, respectively. The slurry was stored in a second tank (tank 2 ) made with a plastic tarp. After the sediment suspended in tanks 1 and 2 had been allowed to settle, the fairly clear supernatant was pumped out of the tanks. Several 1-L samples of the supernatant water were composited to determine the concentrations of SS and "adjusted" TSS. The sediment remaining in the bottom of the two tanks was placed in a hot house and dried for several days. The temperature of the hot house was approximately $105^{\circ} \mathrm{F}$. The dried sediment was weighed, and subsamples were collected for PSD and VSS analysis.

\section{Measured Weight of Sediment in Sump}

The dry weight of the sediment removed from the sediment-storage sump was $415 \mathrm{lb}$. This weight is low because it was not possible to remove all the sediment from the sump. The circular shape of the control structure in the settling device prevented the suction hoses from reaching the outer edge of the sump. Water remaining in the sump made it impossible to use a camera to assess how much sediment was left in the sump. Infiltration of groundwater quickly replaced the water pumped from the sump. Another method was selected to estimate the amount sediment remaining in the sump.

The dry weight of sediment remaining in the sump was estimated by multiplying the measured dry device weight of the sediment removed from the sump times a conservative estimate of the wet volume of sediment remaining in the sump. A dry device weight of $53 \mathrm{lb} / \mathrm{ft}^{3}$ was calculated by dividing the volume of the wet sediment removed from the sump into the dry weight of the sediment. To estimate the wet volume of sediment left in the sump, an estimate was made of the width and depth of the sediment remaining around the edge of the circular sump.

The sediment deposited in the sump formed a shallow cone (Robert Andoh, Hydro International, oral commun., 2007), so the depth of the sediment around the edge of the sump was less than in the middle. The average depth of sediment measured in the center of the sump was $0.35 \mathrm{ft}$. It was assumed that the depth around the edge was about one-half of the depth in the middle or about $0.18 \mathrm{ft}$. The width of the deposit was assumed to be $4 \mathrm{in}$. around the edge of the sump, which is $6 \mathrm{ft}$ in diameter. The wet volume of the sediment remaining in the sump was determined to be about $1.1 \mathrm{ft}^{3}$. By multiplying the device dry weight times the assumed wet volume of sediment left in the sump, the amount of sediment left in the sump was estimated to be $58 \mathrm{lb}$. This brings the total sediment trapped in the device during the study period to approximately $473 \mathrm{lb}$.

\section{Weight of Sediment in Sump Using Inlet and Outlet Suspended-Sediment Loads}

The difference between the inlet and outlet SS loads for the sampled runoff events was $609 \mathrm{lb}$ (table 9). Although this number is about 1.3 times higher than that in the sump, it still compares somewhat favorably with the estimate of $473 \mathrm{lb}$ trapped in the device. However, the $611 \mathrm{lb}$ of sediment does not include the SS inlet and outlet loads for all the unsampled runoff events. Unsampled events during the monitoring period total 48. Rainfall less than 0.2 in. in depth represented 31 events. Most low volume runoff events did not produce a sufficient water depth in the pipes to collect samples. Low runoff volumes from these events probably do contribute a small amount to the total SS load. The SS load would be more affected by the 17 unsampled events that had rainfall depths between 0.2 and $1.0 \mathrm{in}$. Only one event with more than a 1-in. rainfall depth was not sampled. A method to estimate inlet and outlet SS loads for unsampled events was developed.

The approach to finding a method for estimating constituent loads for unsampled runoff events started with trying to estimate SS loads for sampled events. Multiple models were developed by using a statistical method of stepwise regression. Rainfall and runoff characteristics were used as the independent variables, and SS load was the dependent variable. Logs of rainfall duration and peak flow were the independent variables that most closely estimated the sampled inlet and outlet SS load. Using these two independent variables in a regression relationship produced reasonably robust correlation coefficient $\left(\mathrm{R}^{2}\right)$ values for the inlet and outlet of 76 and 78 percent, respectively. Estimates of the SS load were determined by retransforming the data set back to original units using the Maximum Likelihood Estimation (MLE) method that is commonly used in environmental disciplines (Helsel and Hirsch, 1992).

To test the regression models for the inlet and outlet SS loads, the measured SS loads at the inlet and outlet were estimated using the MLE concentrations and runoff volumes for the sampled runoff events. The total modeled SS load for the sampled events was $1,320 \mathrm{lb}$ at the inlet and $985 \mathrm{lb}$ at the outlet. The measured inlet and outlet SS loads for sampled events were 1,590 and $979 \mathrm{lb}$, respectively. These values are very close to the modeled ones with only a 17-percent difference at the inlet and a -5 percent difference at the outlet. The regression models should provide good estimates of SS loads for the unsampled events.

The estimated event loads for unsampled events were $1,451 \mathrm{lb}$ at the inlet and $1,118 \mathrm{lb}$ at the outlet. The unsampled runoff events were estimated to contribute $333 \mathrm{lb}$ of sediment to the sump. By adding the measured and estimated SS loads, the total inlet SS load for the runoff events was 3,040 lb, and the total SS load at the outlet was 2,100 lb. The difference between these two numbers indicated that the amount of 
sediment that should have been retained at the bottom of the tank was $942 \mathrm{lb}$.

A combination of measured and estimated inlet and outlet SS loads overestimated the amount of sediment retained in the tank by a factor of two. This result certainly indicates that the efficiency calculation might overestimate for SS, and the same might be true for some of the other constituents containing a lot of particulate matter, such as TZn. Because the removal efficiency results presented in tables 8 and 11 might be overestimates, it was important to evaluate sources of error in the SS loads and to select a method for estimating the potential error in the SS efficiencies.

\section{Adjustments to Suspended-Sediment Loads}

It is unlikely that the process of retrieving and weighing the amount of sediment trapped in the sump was off by a factor of two. Although there is some error in weighing the sediment in the sump, the difference between the calculated and measured weight of the sediment in the sump is more likely due to a positive bias in the SS loads. Some of that bias could be from the loads estimated for the unsampled runoff events, but the regression equations seem to produce reasonably good numbers. If estimated SS loads for the unsampled events were high by as much as 50 percent, the total estimate for the weight of sediment in the sump would still be about 1.6 times higher than the measured load. A more likely cause of positive bias in the SS loads is the stratification of particles in the inlet and outlet pipes.

Recent efforts to evaluate the accuracy of sampling for concentrations of SS and TSS at the bottom of stormwater pipes have shown that the concentration of larger particles is higher near the bottom of a pipe (Smith, 2002; DeGroot and others, 2009; Smith and Granato, 2010). Samples collected from throughout the water column at the 12-in. diameter inlet of an oil-grit settling device in Boston, Massachusetts, showed that the concentration of particles greater than $62 \mu \mathrm{m}$ in diameter tended to be higher at the bottom of the pipe (Smith, 2002; Smith and Granato, 2010). At a flow rate of
$0.45 \mathrm{ft}^{3}$, the samples collected at $1 \mathrm{in}$. from the bottom of the inlet pipe had concentrations of SS that were twice as high as the samples collected 2.5 in. from the bottom. Testing at the St. Anthony Falls Laboratory in Minnesota concluded that automatic samplers were not accurately monitoring particles larger than coarse silt when a single intake is located at the bottom of the pipe (DeGroot and others, 2009). Compared to the concentration fed into a 1.5 -ft diameter pipe, the measured concentrations of coarse silt ( 44 to $88 \mu \mathrm{m}$ in diameter) and fine sand (125 to $180 \mu \mathrm{m}$ in diameter) were about 1.5 and 5 times higher, respectively, than they should be. For coarser sand (250 to $355 \mu \mathrm{m}$ in diameter), the measured concentrations were about 10 to 13 times higher. Without sufficient vertical mixing, the stratification of larger particles in a pipe appears to impose a positive bias on the measured concentrations of SS and TSS.

Smith (2002) applied an adjustment factor to inlet loads in the oil-grit settling device because the inlet loads would have been overestimated without the adjustment. The outlet loads were not adjusted because the outlet samples contained very few particles greater than $62 \mu \mathrm{m}$ in diameter. A similar adjustment factor cannot be developed with the data from the study described in this report, but the median percentage of particles greater than $63 \mu \mathrm{m}$ in diameter was more than twice that observed in the Smith (2002) study. For seventeen runoff events, the average percentages of particles less than $63 \mu \mathrm{m}$ in diameter were 55 percent for the device inlet and 57 percent for the outlet (table 12). Three of the largest runoff events had median percentages of particles greater than $63 \mu \mathrm{m}$ in diameter of 62 percent for the device inlet and 33 percent for the outlet. Stratification of the particles was even more likely for the largest events because more than 32 percent of the particles at the inlet were greater than $500 \mu \mathrm{m}$ in diameter.

The approach to reducing the bias in the SS loads involved reducing the concentrations of each particle-size range greater than $63 \mu \mathrm{m}$ in diameter until the difference between the inlet and outlet SS loads matched the measured weight of sediment in the sump. The concentrations were

Table 12. Comparison of average particle-size distributions between 3 runoff events and 17 other runoff events for parking lot in Madison, Wisconsin, November 2005-August 2006.

[All data are in percent by mass; $<$, less than; $\mu \mathrm{m}$, micrometer in diameter]

\begin{tabular}{|c|c|c|c|c|c|c|c|c|c|}
\hline Event group & \multicolumn{9}{|c|}{ Particle size ( $\mu \mathrm{m})$} \\
\hline \multicolumn{10}{|c|}{ Inlet pipe } \\
\hline Three events & 68 & 52 & 45 & 38 & 31 & 26 & 21 & 17 & 8 \\
\hline Other 17 events & 92 & 82 & 71 & 55 & 44 & 35 & 30 & 24 & 11 \\
\hline \multicolumn{10}{|c|}{ Outlet pipe } \\
\hline Three events & 99 & 95 & 83 & 67 & 54 & 48 & 40 & 29 & 15 \\
\hline Other 17 events & 97 & 90 & 76 & 57 & 45 & 37 & 31 & 24 & 11 \\
\hline
\end{tabular}


reduced for the particle-size ranges of 63 to 125,125 to 250 , and greater than $250 \mu \mathrm{m}$ in diameter for both the inlet and the outlet. Based on work done at the St. Anthony Falls Laboratory, a different percentage reduction was selected for each particle-size range. The percentage reductions selected for the ranges of 63 to 125,125 to 250 , and greater than $250 \mu \mathrm{m}$ in diameter were 3,15 , and 30 percent, respectively. The 15 - and 30 -percent reductions were determined by multiplying the 3 -percent value by 5 and 10, respectively. These two multiples approximate the relative errors observed at the St. Anthony Falls Laboratory for fine and coarser sand.

Although the testing by DeGroot and others (2009) supports using much larger reductions than 3,15 , and 30 percent, these values were based on the Degroot's relative reductions for each particle-size range and produced a value close to the measured weight of sediment in the sump. The much smaller reductions are justifiable when the differences between the laboratory and field testing are considered. Because the particles in both the inlet and the outlet water only traveled a short distance before the sampler intake tube, they had much less time to settle to the bottom than the particles injected into the pipe at the St. Anthony Falls Laboratory. After being well mixed in the flow splitter, the inlet water only had $2 \mathrm{ft}$ to travel before the intake tube. At the St. Anthony Falls Laboratory, the particles traveled about $35 \mathrm{ft}$ before reaching the intake tube. In addition, the settling rate for many of particles in the runoff water was probably less than the silica sand used for testing by DeGroot and others (2009). With inlet VSS concentrations that averaged 32 percent of the average "adjusted" TSS concentrations many of the particles would have a relatively low specific gravity and be much less likely to settle to the bottom of the pipe.

The difference between the "adjusted" SS loads for the inlet and outlet of the hydrodynamic-settling device is $505 \mathrm{lb}$ (table 13). This value is very close to the weight of $473 \mathrm{lb}$ measured for the sediment removed from the sump. Although there is a large degree of uncertainty in applying the laboratory findings from the St. Anthony Falls Laboratory to data collected from the environment, the process of matching the measured weight of sediment in the sump gives some validity to the magnitude of the adjustments. Because the relatively small adjustments were only needed for the sand-sized particles, the stratification of the sand-sized particles in the inlet and outlet pipes was probably responsible for overestimating the weight of sediment in the sump. However, the uncertainty in using results from the St. Anthony Falls Laboratory to adjust the SS loads still makes it inappropriate to use the "adjusted" SS loads to calculate new SOL values for SS (table 9).

The appropriate use of the "adjusted" SS loads is to determine if the error caused by the stratification increases or decreases the SOL value. The SOL for SS using the adjusted sampled SS loads is 30 percent. Because this is less than the 38 percent calculated for the sampled events (table 9), the stratification of the sand particles increases the SOL values. This positive bias is probably true for all of the particulate constituents. The SOLs (table 9) are probably overestimated except the ones for DP. Future studies need to address the stratification issue by modifying the sampling methods or by developing site-specific adjustment equations, such as developed by Smith (2002), and Smith and Granato (2010).

\section{Particle-Size Distribution of Sediment Retained in Sump}

Five subsamples were randomly collected from the sump sediment, and each subsample was sieved to determine the PSD. Volatile solids were also determined for each of the five subsamples. Average PSD and VSS values were determined for the sediment in the sump by averaging the results of the five subsamples. At 8 percent in the sump, the average VSS was much smaller than the average of 32 percent observed for the inlet water samples. With a lower specific gravity, volatile solids such as bits of vegetation are less likely to be trapped by the settling device. The majority of the particles trapped in the device were in the sand or larger sized particles (table 14). More than 80 percent of the particles in the sump were $250 \mu \mathrm{m}$

Table 13. Monitored and estimated loads after concentrations of suspended sediment were adjusted for three largest particle sizes at inlet and outlet of hydrodynamic-settling device in Madison, Wisconsin, November 2005 and September 2006.

[All values in pounds; SS, suspended sediment]

\begin{tabular}{lccc}
\hline \multicolumn{1}{c}{ Site } & $\begin{array}{c}\text { Adjusted monitored } \\
\text { SS load' }\end{array}$ & $\begin{array}{c}\text { Adjusted estimated } \\
\text { SS load' }\end{array}$ & $\begin{array}{c}\text { Total adjusted } \\
\text { SS load }\end{array}$ \\
\hline Inlet & 1,220 & 1,115 & 2,335 \\
Outlet & 855 & 975 & 1,830 \\
\hline
\end{tabular}

${ }^{1}$ Percentages of 3,15 , and 30 were used on each monitored runoff event to reduce SS concentration for particle sizes 63 to 125,125 to 250 , and greater than 250 micrometers in diameter, respectively. 
Table 14. Particle-size distribution for sediment samples collected in hydrodynamic-settling device in Madison, Wisconsin, September 2006.

$[<$ less than $]$

\begin{tabular}{cccccccccc}
\hline $\begin{array}{c}\text { Particle size , } \\
\text { in micrometers }\end{array}$ & $\mathbf{< 1 6 , 0 0 0}$ & $\mathbf{< 8 , 0 0 0}$ & $\mathbf{< 4 , 0 0 0}$ & $\mathbf{< 2 , 0 0 0}$ & $\mathbf{< 1 , 0 0 0}$ & $\mathbf{< 5 0 0}$ & $\mathbf{< 2 5 0}$ & $<\mathbf{1 2 5}$ & $<\mathbf{6 3}$ \\
\hline Percent less than & 97 & 95 & 91 & 82 & 69 & 45 & 19 & 7 & 3 \\
\hline
\end{tabular}

in diameter or larger. This finding supports the observed high removal efficiencies for particles greater than $250 \mu \mathrm{m}$ in diameter but the very low removal efficiencies for particles smaller than $250 \mu \mathrm{m}$ in diameter (table 9)

Similar PSDs were observed for the sediment removed from the sumps of two other hydrodynamic-settling devices (Waschbusch and others, 1999; Horwatich and others, 2010). The majority of the particles trapped in their sumps were in the sand-sized fraction. About 80 percent of the particles were greater than $250 \mu \mathrm{m}$ in diameter for the Madison study (Waschbusch and others, 1999), and the Milwaukee study had about 60 percent of the particles greater than $250 \mu \mathrm{m}$ in diameter (Horwatich and others, 2010).

\section{Summary}

The U.S. Environmental Protection Agency (EPA) created the Environmental Technology Verification Program to verify the performance claims made by manufacturers of proprietary stormwater control practices. The National Sanitation Foundation International was funded by the EPA to distribute funds for the program and to ensure the quality of the data collection. The Wisconsin Department of Natural Resources (WDNR) has used the results of the verification program to develop technical standards for proprietary stormwater control practices. To support these efforts of assigning appropriate pollution reduction efficiencies to proprietary stormwater control practices, the U.S. Geological Survey in cooperation with WDNR, the City of Madison, cities in the Waukesha Permit Group, Hydro International, Earth Tech, Inc., and National Sanitation Foundation International and the EPA monitored the performance of a hydrodynamic-settling device installed at the stormwater discharge point of a city water utility administration building site in Madison, Wis. An employee parking lot and roofs composed most of the drainage area.

Sedimentation is the principle process for removing pollutants in the settling device's single treatment chamber. The 6-ft diameter device installed in 2004 for this study was sized to treat flows up to $3 \mathrm{ft}^{3} / \mathrm{s}$, and it bypassed any flows in excess of $3 \mathrm{ft}^{3} / \mathrm{s}$. Only three stormwater runoff events from November 2005 through September 2006 had significant bypass volumes ranging from 10 to 20 percent of the total runoff volume.

Twenty-three of the runoff events monitored for flow and water quality at the device's inlet and outlet were used to calculate the percentage pollutant reduction for the device. Bypass flow and water-quality data were included in the calculations to determine the efficiency of the system for the three runoff events with bypass. Of the 28 water-quality constituents analyzed in the water samples, only suspended sediment (SS), "adjusted" total suspended solids (TSS), volatile suspended solids (VSS), dissolved phosphorus (DP)S, and total recoverable zinc (TZn) showed the difference between the inlet and outlet concentrations to be statistically different at the 84-percent confidence level or greater. Some of the TSS concentrations were "adjusted" to add the particles that remained on the sieves during sample processing. Device outlet concentrations for TZn and VSS were significantly higher than the inlet concentrations. Efficiency calculations were only done for constituents with a significant difference between the device inlet and outlet concentrations. Because nine runoff events did not have inlet VSS concentrations, they were not included in the efficiency calculations.

Removal efficiency of the hydrodynamic-settling device was calculated using the efficiency ratio and summation of loads (SOL) methods. Using the efficiency ratio method, the device reduced concentrations of SS and DP by 19 and 15 percent, respectively. Using the efficiency ratio method, the device increased "adjusted" TSS and TZn concentrations by 5 and 19, respectively. Bypass occurred for 3 of the 23 runoff events used in this assessment, and the bypass flow and waterquality concentrations were used to determine the efficiency of the bypass system. Concentrations of SS, "adjusted" TSS, and DP were reduced for the system by 18,5 , and 18 , respectively, however TZn increased by 5 percent. The loads of SS, "adjusted" TSS, and DP were reduced using the SOL method for the settling device by 38,9 , and 19 percent, respectively, and TZn increased by 13 percent. For the bypass system, the loads of SS, "adjusted" TSS, and DP had percentage reductions of 39,12, and 22, respectively, and a 4-percent increase for TZn. Although the SOL method calculated percentage reductions for SS and "adjusted" TSS that were twice those for the efficiency ratio method, just removing data for the two large runoff events on August 23 and 24, 2006, from the SOL calculation brought the reduction for SS down to 16 and increased the load for the "adjusted" TSS by 4 percent.

The amounts of runoff and solids concentrations were unexpectedly high for runoff events on August 23 and 24, 2006 , because a clogged stormwater inlet caused overflow from an adjacent city recycling facility. These two events were 
so large they represented 70 percent of the inlet load for the 23 sampled events. The effect of the two large events not only demonstrates potential differences between the two methods of determining efficiencies of a device but also shows the importance of evaluating the uniqueness of any runoff events when calculating the SOL.

Suspended-sediment removal efficiencies for individual runoff events varied from as low as -47 percent to as high as 70 percent. Using the ratio of VSS to "adjusted" TSS as an indicator of specific gravity of the particles, one source of variability was the wide range in the percentage of VSS. The range in percentage of VSS for runoff events was from 16 to 67 percent with an average of 41 percent for 14 events. Changes in peak flows by themselves do not seem to be good indicators of changes in removal efficiencies except when a negative efficiency might be expected as peak flows approach the design flow at the inlet. Some of the variability was probably due to the large variability in the percentage of sand in the samples and the large average amount of sand in the samples of about 48 percent. The strongest relationship observed between removal efficiency and the PSDs was the increasing SS efficiency when the amount of particles greater than $125 \mu \mathrm{m}$ in diameter exceeded 45 percent.

The SOL method was used to determine percentage SS load reduction for six different particle sizes for both the settling device and bypass system. Essentially no reduction was observed for particles less than $125 \mu \mathrm{m}$ in diameter, and about a 90-percent reduction occurred for particles greater than $250 \mu \mathrm{m}$ in diameter. The high removal efficiencies for particles greater than $250 \mu \mathrm{m}$ in diameter was further supported by the fact that more than 80 percent of the particles trapped in the sump were greater than $250 \mu \mathrm{m}$ in diameter. These results support the manufacture's claim of achieving a high percentage reduction for particles greater than $250 \mu \mathrm{m}$ in diameter.

Stratification of larger particles in the settling device inlet and outlet pipes appeared to result in a positive bias in the SOL for SS. When the difference between the inlet and outlet loads overestimated the weight of the sediment retained in the sump by a factor of two, the cause was assumed to be the positioning of the sampling intakes at the bottom of the pipes where the concentration of larger particles can be higher. The approach to reducing the bias in the SS loads involved lowering the concentrations of each particle-size range greater than $63 \mu \mathrm{m}$ in diameter until the difference between the inlet and outlet SS loads matched the weight of sediment in the sump. The SOL for SS using the modified inlet and outlet SS loads was 30 percent. Future studies need to address the stratification issue by modifying the sampling methods or by developing site-specific adjustment equations.

\section{References}

American Public Health Association and others, 1989, Standard methods for the examination of water and wastewater (17th ed.): Washington, D.C., American Public Health Association [variously paged].

Bannerman, R.T., Baun, K., Bohn, M., Hughes, P.E., and Graczyk, D.J., 1983, Evaluation of urban nonpoint source pollution management in Milwaukee County, Wisconsin-volume 1 for U.S. Environmental Protection Agency, Region V: Wisconsin Department of Natural Resources Publication PB 84-114164 [variously paged].

Bannerman, R.T., Konrad, J., Becker, D., Simsiman, G., Chesters, G., Goodrich-Mahoney, J., and Abrams, B., 1979, Surface water quality monitoring data-volume 3, The IJC Menomonee River Watershed Study: Chicago, U.S. Environmental Protection Agency, EPA-905/4-79029-C [variously paged].

Bannerman, R.T., Owens, D.W., Dodds, R.B., and Hornewer, N.J., 1993, Sources of pollutants in Wisconsin stormwater: Water Science Technology, v. 28, no. 3-5, p. 241-259.

Bannerman, R.T., Legg, A.D., and Greb, S.R., 1996, Quality of Wisconsin stormwater 1989-94: U.S. Geological Survey Open-File Report 96-458, 26 p.

Bochis-Micu, C., and Pitt, R., 2005, Impervious surfaces in urban watersheds, in Proceedings of WEFTEC.05, the 78th Annual Water Environment Federation Annual Technical Exhibition and Conference (CD-ROM), Washington, D.C., Oct. 29-Nov. 2, 2005: Water Environment Federation, Alexandria, Virginia, p. 3124-3141.

Booth, D.B., and Reinelt, L.E., 1993, Consequences of urbanization on aquatic systems - measured effects, degradation thresholds, and corrective strategies, in Watersheds' 93, Alexandria, Virginia, 1993, Proceedings: U.S. Environmental Protection Agency, p. 545-550.

Burton, G.A., Jr., and Pitt, R.E., 2002, Stormwater effects handbook - a toolbox for watershed managers, scientists, and engineers: Boca Raton, Florida, Lewis Publishers, 929 p.

California Department of Transportation, 2004, BMP Retrofit Pilot Program Final Report: Sacramento, California, Division of Environmental Analysis, Report ID CTSW-RT-01050 [variously paged]. 
Clark, S.E., and Siu, C.S., 2008, Measuring solids concentration in stormwater runoff - comparison of analytical methods: Environmental Science and Technology, v. 42, no. 2, p. 511-516.

Clark, S.E., Siu, C.Y.S., Pitt, R., Roenning, C.D., and Treese, D.P., 2008, Peristaltic pump autosamplers for solids measurement in stormwater runoff: Water Environment Research, v. 80, 9 p.

Corsi, S.R., Greb, S.R., Bannerman, R.T., and Pitt, R.E., 1999, Evaluation of the multi-chambered treatment train, a retrofit water-quality management practice: U.S. Geological Survey Open-File Report 99-270, 24 p.

Cristina, C., Tramonte, J., and Sansalone, J.J., 2002, A granulometry-based selection methodology for separation of traffic-generated particles in urban highway snowmelt runoff: Water, Air and Soil Pollution, v. 136, p. 33-53.

DeGroot, G.P., Gulliver, J.S., and Mohseni, O., 2009, Accurate sampling of suspended solids, in World Environmental and Water Resources Congress 2009 and Great Rivers 2009 ASCE Conference, Proceedings: Kansas City, Missouri, American Society of Civil Engineers, p. 807-813.

de Ridder, S.A., Darcy, S.I., Calvert, P.P., and Lenhart, J.H., 2002, Influence of analytical method, data summarization method and particle size on total suspended solids removal efficiency, in Strecker, E.W., and Huber, W.C., eds., Global solutions for urban drainage, proceedings of the 9th International Conference on Urban Drainage, Portland, Oregon, 2002: American Society of Civil Engineers report no. PD-02-006.1

Design Analysis Associates, 2001, "Smart" SDI-12 tipping bucket rain gauge - model H-340SDI, WATERLOG series owner's manual, ver. 1.1: Logan, Utah, 26 p.

Driscoll, E.D., Shelley, P.E., and Strecker, E.W., 1990, Pollutant loadings and impacts from highway stormwater runoff, volume I-design procedure: Federal Highway Administration Final Report FHWA-RD-88-006, 61 p.

Field, R., Tafuri, A.N., Muthukrishnan, S., Acquisto, B.A., and Selvakumar, S., 2006, The use of best management practices (BMPs) in urban watersheds: Lancaster, Pennsylvania, DEStech Publications,. ISBN 1-932078-46-0 [variously paged].

Fowler, G.D., Roseen, R.M., Ballestero T.P., Guo, Q., and Houle, J., 2009, Sediment monitoring bias by autosampler in comparison with whole volume sampling for parking lot runoff, in World Environmental and Water Resources Congress 2009, Kansas City, Missouri, Proceedings: Reston, Virginia, American Society of Civil Engineers, p. 1-9.
Graham, M.D., and Beckman Coulter, Inc., 2003, The Coulter Principle- foundation of an industry: Journal of the Association for Laboratory Automation, v. 8, no. 6, p. 72-81.

Gray, J.R., Glysson, G.D., Torcios, L.M., and Schwartz, G., 2000, Comparability of suspended-sediment concentration and total suspended solids data: U.S. Geological Survey Water-Resources Investigation Report 00-4191, 12 p.

Greb, S.R., and Bannerman, R.T., 1997, Influence of particle size on wet pond effectiveness: Water Environment Research, v. 69, no. 6, p. 1134-1138.

Helsel, D.R., and Hirsch, R.M., 1992, Statistical methods in water resources: New York, Elsevier, 522 p.

Horner, R.R., Skupien, J.J., Livingston, E.H., and Shaver, E.H., 1994, Fundamentals of urban runoff management-technical and institutional issues: Washington, D.C., Terrene Institute and U.S. Environmental Protection Agency, p. 43-56.

Horowitz, A.J., Hayes, T.S., Gray, J.R., and Capel, P.D., 1997, Selected laboratory tests of the whole-water sample splitting capabilities of the 14-liter churn and the Teflon cone splitters: U.S. Geological Survey Office of Water Quality Technical Memorandum 97.06, $28 \mathrm{p}$.

Horwatich, J.A., and Bannerman, R.T., 2010, Parking lot runoff quality and treatment efficiency of a stormwater-filtration device, Madison, Wisconsin, 2005-07: U.S. Geological Survey Scientific Investigations Report 2009-5196, 50 p.

Horwatich, J.A., Bannerman, R.T., and Pearson, Robert, 2010, Highway-runoff quality and treatment efficiency of a hydrodynamic-settling device and a stormwater-filtration device in Milwaukee, Wisconsin: U.S. Geological Survey OpenFile Report 2010-5160, $50 \mathrm{p}$.

Horwatich, J.A., Corsi, R.S., and Bannerman, R.T., 2004, Effectiveness of a pressurized stormwater filtration system in Green Bay, Wisconsin - a study for the Environmental Technology Verification Program of the U.S. Environmental Protection Agency: U.S. Geological Survey Scientific Investigations Report 2004-5222, 19 p.

House, L.B., Waschbusch, R.J., and Hughes, P.E., 1993, Water quality of an urban wet detention pond in Madison Wisconsin, 1987-88: U.S. Geological Survey Open-File Report 93-172, $57 \mathrm{p}$.

Kayhanian, M., Rasa, E., Vichare, A., and Leatherbarrow, J.E., 2008, Utility of suspended solid measurements for stormwater runoff treatment: Journal of Environmental Engineering, v. 134 , no. 9 , p. $712-721$.

Legg, A.D., Bannerman, R.T., and Panuska, J., 1996, Variation in the relation of rainfall to runoff from residential lawns in Madison, Wisconsin, July and August 1995: U.S. Geological Survey Water-Resources Report 96-4196, 11 p. 
Mahler, B.J., Van Metre, P.C., Bashara, T.J., Wilson, J.T., and Johns, D.A., 2005, Parking lot sealcoat—an unrecognized source of urban polycyclic aromatic hydrocarbons: Environmental Science and Technology, v. 39, no. 15, p. 5560-5566.

Masterson, J.P., and Bannerman, R.T., 1994. Impacts of stormwater runoff on urban streams in Milwaukee County, Wisconsin, in National Symposium on Water Quality, Proceedings: American Water Resource Association, p. 123-133.

Minton, G.R., 2005, Stormwater treatment biological, chemical, and engineering principals: Seattle, Washington, Sheridan Books, Inc., 472 p.

National Climatic Data Center, 2003, Local climatological data-Madison, Wisconsin - annual summary with comparative data: Asheville, North Carolina, National Climatic Data Center, ISSN 0198-5728, 8 p.

National Cooperative Highway Research Program, 2006, Evaluation of best management practices for highway runoff control: Washington, D.C., Transportation Research Board, NCHRP Report 565, 111 p., 2 app.

National Oceanic and Atmospheric Administration, 2007, Dane County Regional Airport Madison precipitation records, 1949-2007: Asheville, North Carolina, National Climatic Data Center, $42 \mathrm{p}$.

Pitt, R., Field, R., Lalor, M., and Brown, M., 1995 Urban stormwater toxic pollutants-assessment, sources and treatability: Water Environment Research , v. 67, no. 3, p. 260-275.

Richards, K.D., Scudder, B.C., Fitzpatrick, F.A., Steuer, J.J., Bell, A.H., Peppler, M.C., Stewart, J.S., and Harris, M.A., 2006, Effects of urbanization on stream ecosystems along an agriculture-to-urban land-use gradient, Milwaukee to Green Bay, Wisconsin, 2003-2004: U.S. Geological Survey Scientific Investigations Report 2006-5101-E, 210 p

Roesner, L.A., Pruden, A., and Kidner, E.M., 2007, Improved protocol for classification and analysis of stormwater-borne solids: Water Environment Research Federation, 04-SW-4, $124 \mathrm{p}$.

Selbig, W.R., and Bannerman, R.T., 2010, Development of a depth-integrated sample arm to reduce solids stratification bias in stormwater sampling: Water Environment Research Federation, v. 83, no. 4, p. 347-357

Selbig, W.R., and Bannerman, R.T., 2007, Evaluation of street sweeping as a stormwater-quality management tool in three residential basins in Madison, Wisconsin: U.S. Geological Survey Scientific Investigations Report 2007-5156, 103 p.
Selbig, W.R., Bannerman, Roger, and Bowman, George, 2007, Improving the accuracy of sediment-associated constituent concentrations in whole-stormwater samples by wet sieving: Journal of Environmental Quality, v. 36, no. 1, p. 226-232.

Smith, K.P., 2002, Effectiveness of three best management practices for highway-runoff quality along the southeast expressway, Boston, Massachusetts: U.S. Geological Survey Water-Resources Investigations Report 02-4059, 62 p.

Smith, K.P., and Granato, G.E., 2010, Quality of stormwater runoff discharged from Massachusetts highways, 2005-07: U.S. Geological Survey Scientific Investigations Report 2009-5269, 198 p.

Steuer, J.J., Selbig, W.R., Hornewer, N.J., and Prey, J., 1997, Sources of contamination in an urban basin in Marquette, Michigan, and an analysis of concentrations, loads, and data quality: U.S. Geological Survey Water-Resources Investigations Report 97-4242, 25 p.

Strecker, E.W., Huber, W.C., Heaney, J.P., Bodine, D., Sansalone, J.J., Quigley, M.M., Pankani, D., Leisenring, M., and Thayumanavan, P., 2005, Critical assessment of stormwater treatment and control selection issues: Water Environment Research Federation, Report no. 02-SW-1, ISBN 1-84339741-2, $290 \mathrm{p}$.

Strecker, E.W., Quigley, M.M., and Urbonas, Ben, 2003, A reassessment of the expanded EPA/ASCE National BMP Database, in National Conference on Urban Storm WaterEnhancing Programs at the Local Level, Chicago, Illinois, 2003, Proceedings: U.S. Environmental Protection Agency, Office of Research and Development, EPA/625/R-03/003, p. 555-574.

U.S. Environmental Protection Agency, 1986, Test methods for evaluation of solid waste ( $3 \mathrm{~d}$ ed.): Washington D.C., Office of Solid Waste and Emergency Response [variously paged].

U.S. Environmental Protection Agency, 1998, National water quality inventory - 1998 report: U.S. Environmental Protection Agency Report EPA-841-F-00-006 [variously paged].

U.S. Environmental Protection Agency, 1999, Preliminary data summary of urban storm water best management practices: U.S. Environmental Protection Agency, EPA821-R-99-012 [variously paged].

U.S. Environmental Protection Agency, 2002a, ETV verification protocol stormwater source area treatment technologies: EPA/NSF wet-weather flow technologies pilot, v.4.1 [variously paged]. 
U.S. Environmental Protection Agency, 2002b, Memorandum on 2002 Integrated Section 305(b) Reports and 303(d) Lists and the impact of the 305(b) Reports on Annual S106 Grant Funding Targets, signed March 1, 2002, by Michael B. Cook, Director, EPA Office of Wastewater Management.

U.S. Environmental Protection Agency, 2007, Environmental Technology Verification Report-stormwater source area treatment device-Hydro International Downstream Defender ${ }^{\circledR}:$ U.S. Environmental Protection Agency, 07/31/ WQPC-WWF, EPA/600/R-07/121, 60 p., accessed September 2007 at http://www.nsf.org/business/water_quality_protection_center/pdf/Hydro_Verification_Report.pdf.

Wang, L., Lyons, J., Kanehl, P., and Bannerman, R., 2001, Impacts of urbanization on stream habitat and fish across multiple spatial scales: Environmental Management, v. 28, p. 255-266.

Waschbusch, R.J., 1999, Evaluation of the effectiveness of urban stormwater treatment unit in Madison, Wisconsin, 1996-97: U.S. Geological Survey Water-Resources Investigations Report 99-4195, 49 p.
Waschbusch, R.J., Selbig, W.R., and Bannerman, R.T., 1999, Sources of phosphorus in stormwater and street dirt from two urban residential basins in Madison, Wisconsin, 199495: U.S. Geological Survey Water-Resources Investigations Report 99-4021, 47 p.

Weber, D.N., and Bannerman, R., 2004, Relationships between impervious surfaces within a watershed and measures of reproduction in fathead minnows (Pimephales promelas): Hydrobiologia, v. 525, p. 215-228.

Wilde, F.D., ed., 2006, Collection of water samples, in National field manual for the collection of waterquality data: U.S. Geological Survey Techniques of Water-Resources Investigations, book 9, chap. A4 [variously paged].

Wisconsin Administrative Code, 2004, Wisconsin Department of Natural Resources - runoff management-chap. NR151: State of Wisconsin [variously paged].

Woodworth, M.T., and Connor, B.F., 2003, Results of the U.S. Geological Survey's analytical evaluation program for standard reference samples distributed in March 2003: U.S. Geological Survey Open-File Report 03-261, 109 p. 



\section{Appendix 1. List of References for Previous Investigations}

Bachhuber, J.A., Horwatich, J.A., Corsi, S.R., and Bannerman, R.T., 2002, Environmental Technology Verification Program - development of a protocol for testing commercial stormwater treatment devices and two case examples in Wisconsin, in StormCon 2002, Marco Island, Florida, 2002, Proceedings: Santa Barbara, California, Forester Communications, $12 \mathrm{p}$.

Bannerman, R.T., Baun, K., Bohn, M., Hughes, P.E., and Graczyk, D.J., 1983, Evaluation of urban nonpoint source pollution management in Milwaukee County, Wisconsin, volume 1 for U.S. Environmental Protection Agency, Region V: Wisconsin Department of Natural Resources Publication PB 84-114164 [variously paged].

Bannerman, R.T., Dodds, R.B., Owens, D.W., and Hughes, P.E., 1992, Source of pollutants in Wisconsin stormwater, volume 1 for U.S. Environmental Protection Agency, Region V: Wisconsin Department of Natural Resources Grant number C9995007-01 [variously paged].

Bannerman, R.T., Legg, A.D., and Greb, S.R., 1996, Quality of Wisconsin stormwater 1989-94: U.S. Geological Survey Open-File Report 96-458, 26 p.

Bannerman, R.T., Owens, D.W., Dodds, R.B., and Hornewer, N.J., 1993, Sources of pollutants in Wisconsin stormwater: Water Science Technology, v. 28, no. 3-5, p. 241-259.

Corsi, S.R., Graczyk, D.J., Owens, D.W., and Bannerman, R.T., 1997, Unit-area loads of suspended sediment, suspended solids, and total phosphorus from small watersheds in Wisconsin: U.S. Geological Survey Fact Sheet 195-97, $4 \mathrm{p}$.

Corsi, S.R., Greb, S.R., Bannerman, R.T., and Pitt, R.E., 1999, Evaluation of the multi-chambered treatment train, a retrofit water-quality management practice: U.S. Geological Survey Open-File Report 99-270, 24 p.

Corsi, S.R., Walker, J.F., Wang, L., Horwatich, J.A., and Bannerman, R.T., 2005, Effects of best-management practices in Otter Creek in the Sheboygan River priority watershed, Wisconsin, 1990-2002: U.S. Geological Survey Scientific Investigations Report 2005-5009, 26 p.

Graczyk, D.G., Hunt, R.J., Greb, S.R., Buchwald, C.A., and Krohelski, J.T., 2003, Hydrology, nutrient concentrations, and nutrient yields in nearshore areas of four lakes in northern Wisconsin, 1999-2001: U.S. Geological Survey WaterResources Investigations Report 03-4144, 64 p.
Graczyk, D.J., Walker, J.F., Horwatich, J.A., and Bannerman, R.T., 2003, Effects of best-management practices in the Black Earth Creek priority watershed, Wisconsin, 1984-98: U.S. Geological Survey Water-Resources Investigations Report 03-4163, $24 \mathrm{p}$.

Greb, S.R., Bannerman, R.T., Corsi, S.R., and Pitt, R.E., 2000, Evaluation of the multichambered treatment train, a retrofit water-quality management practice: Water Environmental Research, v. 72, no. 2, p. 207-216.

Horwatich, J.A., and Bannerman, R.T., 2010, Parking lot runoff quality and treatment efficiency of a stormwater-filtration device, Madison, Wisconsin, 2005-07: U.S. Geological Survey Scientific Investigations Report 2009-5196, 50 p.

Horwatich, J.A., Corsi, R.S., and Bannerman, R.T., 2004, Effectiveness of a pressurized stormwater filtration system in Green Bay, Wisconsin - a study for the Environmental Technology Verification Program of the U.S. Environmental Protection Agency: U.S. Geological Survey Scientific Investigations Report 2004-5222, 19 p.

House, L.B., Waschbusch, R.J., and Hughes, P.E., 1993, Water quality of an urban wet detention pond in Madison, Wisconsin, 1987-88: U.S. Geological Survey Open-File Report 93-172, $57 \mathrm{p}$.

Legg, A.D., Bannerman, R.T., and Panuska, J., 1996, Variation in the relation of rainfall to runoff from residential lawns in Madison, Wisconsin, July and August 1995: U.S. Geological Survey Water-Resources Report 96-4196, 11 p.

Martinelli, T.J., Waschbusch, R.J., Bannerman, R.T., and Wisner, A., 2002, Pollutant loading to stormwater runoff from highways - impact of a freeway sweeping program: Wisconsin Department of Transportation Final Report WI-11-01, $94 \mathrm{p}$.

Owens, D.O., Jopke, P., Hall, D.W., Balousek, J., and Roa, A., 2000, Soil erosion from two small construction sites, Dane County, Wisconsin: U.S. Geological Survey Fact Sheet FS-109-00, 4 p.

Robertson, D.M., Graczyk, D.J., Garrison, P.J., Wang, L., LaLiberte, G., and Bannerman, R.T., 2006, Nutrient concentrations and their relations to the biotic integrity of wadeable streams in Wisconsin: U.S. Geological Survey Professional Paper 1722, $156 \mathrm{p}$.

Selbig, W.R., and Bannerman, R.T., 2007, Evaluation of street sweeping as a stormwater-quality management tool in three residential basins in Madison, Wisconsin: U.S. Geological Survey Scientific Investigations Report 2007-5156, 103 p. 
Selbig, W.R., and Bannerman, R.T., 2008, A comparison of runoff quantity and quality from two small basins undergoing implementation of conventional and low-impactdevelopment (LID) strategies: Cross Plains, Wisconsin, water years 1999-2005: U.S. Geological Survey Scientific Investigations Report 2008-5008, 66 p.

Selbig, W.R., Bannerman, R.T., and Bowman, G., 2006, Use of wet sieving to improve the accuracy of sediment and sediment-associated constituent concentrations in wholewater samples, in 8th Federal Interagency Sedimentation and Hydrologic Modeling Conference, Reno, Nevada, 2006, Proceedings of the Federal Interagency Sedimentation Conferences, 1947 to 2006.: Subcommittee on Sedimentation, p. $878-885$.

Selbig, W.R., Bannerman, R.T., and Bowman, G., 2007, Improving the accuracy of sediment-associated constituent concentrations in whole storm water samples by wet sieving: Journal of Environmental Quality, v. 36, no. 1, 7 p.

Steuer, J.J., Selbig, W.R., Hornewer, N.J., and Prey, J., 1997, Sources of contamination in an urban basin in Marquette, Michigan, and an analysis of concentrations, loads, and data quality: U.S. Geological Survey Water-Resources Investigations Report 97-4242, 25 p.

Steuer, J.J., Selbig, W.R., and Hornewer, N.J., 1996, Contaminant concentration in stormwater from eight Lake Superior basin cities, 1993-94: U.S. Geological Survey Open-File Report 96-122, $16 \mathrm{p}$.

Stewart, J.S., Wang, L., Lyons, J., Wierl, J.A., and Bannerman, R.T., 2001, Influences of watershed, riparian corridors, and reach-scale characteristics on aquatic biota in agricultural watersheds: Journal of the American Water Resources Association, v. 37 , p. $1475-1487$.

Stuntebeck, T.D., 1995, Evaluating barnyard best management practices in Wisconsin using upstream-downstream monitoring: U.S. Geological Survey Fact Sheet 221-95, 4 p.

Stuntebeck, T.D., and Bannerman, R.T., 1998, Effectiveness of barnyard best management practices in Wisconsin: U.S. Geological Survey Fact Sheet 051-98, 4 p.

Stuntebeck, T.D., Komiskey, M.J., Owens, D.W., and Hall, D.W., 2008, Methods of data collection, sample processing, and data analysis for edge-of-field, streamgaging, subsurface-tile, and meteorological stations at Discovery Farms and Pioneer Farm in Wisconsin, 2001-07: U.S. Geological Survey Open-File Report 2008-1015, 60 p.

U.S. Environmental Protection Agency, 1982, Results of the Nationwide Urban Runoff Program-volume II, appendices: U.S. Environmental Protection Agency [variously paged].
U.S. Environmental Protection Agency, 1983, Results of the Nationwide Urban Runoff Program - volume I, final report: Washington, D.C., Water Planning Division[variously paged].

U.S. Environmental Protection Agency, 2004a, Environmental Technology Verification Report-stormwater source area treatment device-Arkal Pressurized Stormwater Filtration System: U.S. Environmental Protection Agency, EPA/600/R-04/084 [variously paged].

U.S. Environmental Protection Agency, July 2004b, Environmental Technology Verification Report-stormwater source area treatment device- - The stormwater management StormFilter using ZPG filter media: U.S. Environmental Protection Agency, 04/17/WQPC-WWF, EPA/600/R-04/125, $65 \mathrm{p}$.

U.S. Environmental Protection Agency, 2005a, Environmental Technology Verification Report- stormwater management StormFilter using perlite filter media: U.S. Environmental Protection Agency, 05/23/WQPC-WWF, EPA 600/R05/137, $56 \mathrm{p}$.

U.S. Environmental Protection Agency, 2005b, Environmental Technology Verification Report-stormwater source area treatment device-Vortechnics, Inc., Vortechs system, model 1000: U.S. Environmental Protection Agency, 05/24/ WQPC-WWF, EPA 600/R-05/140, 66 p.

Walker, J.F., Graczyk, D.J., Corsi, S.R., Owens, D.W., and Wierl, [Horwatich] J.A., 1995, Evaluation of nonpointsource contamination, Wisconsin - land-use and best-management-practices inventory, selected streamwater-quality data, urban-watershed quality assurance and quality control, constituent loads in rural streams, and snowmelt-runoff analysis, water year 1994: U.S. Geological Survey OpenFile Report 95-320, 21 p.

Waschbusch, R.J., 1995, Stormwater-runoff data in Madison, Wisconsin, 1993-94: U.S. Geological Survey Open-File Report 95-733, $33 \mathrm{p}$.

Waschbusch, R.J., 1999, Evaluation of the effectiveness of urban stormwater treatment unit in Madison, Wisconsin, 1996-97: U.S. Geological Survey Water-Resources Investigations Report 99-4195, 49 p.

Waschbusch, R.J., 2003, Data and methods of a 1999-2000 street sweeping study on an urban freeway in Milwaukee County, Wisconsin: U.S. Geological Survey Open-File Report 03-93, 41 p.

Waschbusch, R.J., Bannerman, R.T., and Greb, S.R., 1997, Yields of selected constituents in street runoff in Madison, Wisconsin, 1994-95: U.S. Geological Survey, written commun. to the Wisconsin Department of Natural Resources, $26 \mathrm{p}$. 
Waschbusch, R.J., Selbig, W.R., and Bannerman, R.T., 1999, Sources of phosphorus in stormwater and street dirt from two urban residential basins in Madison, Wisconsin, 199495: U.S. Geological Survey Water-Resources Investigations Report 99-4021, 47 p.

Weigel, B.M., Emmons, E., Stewart, J.S., and Bannerman, R., 2005, Buffer width and continuity for preserving stream health in agricultural landscapes: Madison, Wisconsin, Wisconsin Department of Natural Resources Research/ Management Findings, Wisconsin Department of Natural Resources, PUB-SS-756 2005, 4 p.
Wierl [Horwatich], J.A., Giddings, E.M.P., and Bannerman, R.T., 1998, Evaluation of a method for comparing phosphorus loads from barnyards and croplands in Otter Creek Watershed, Wisconsin: U.S. Geological Survey Fact Sheet FS 168-98, 4 p.

Wierl, [Horwatich], J.A., Rappold, K.F., and Amerson, F.U., 1996, Summary of the land-use inventory for the nonpointsource evaluation monitoring watersheds in Wisconsin: U.S. Geological Survey Open-File Report 96-123, 23 p. 
Appendix 2. Concentrations of selected water-quality constituents in field-equipment blank samples collect at inlet, outlet, and bypass of hydrodynamic-settling device in Madison, Wisconsin, October 2005 and May 2006.

[LOD, limit of detection; LOQ, limit of quantification; mg/L, milligrams per liter; <, less than; - , no sample processed; $\mu \mathrm{g} / \mathrm{L}$, micrograms per liter]

\begin{tabular}{|c|c|c|c|c|c|c|c|c|c|c|}
\hline \multirow[b]{2}{*}{ Constituent } & \multirow[b]{2}{*}{ Unit } & \multicolumn{3}{|c|}{$\begin{array}{c}\text { Blank1 } \\
\text { 10/4/2005 }\end{array}$} & \multicolumn{3}{|c|}{$\begin{array}{l}\text { Blank2 } \\
\text { 5/8/2006 }\end{array}$} & \multicolumn{3}{|c|}{ Blank2.1 } \\
\hline & & Inlet & Outlet & Bypass & Inlet & Outlet & Bypass & Outlet & LOD & LOQ \\
\hline $\begin{array}{l}\text { Suspended-sediment } \\
\text { concentration }\end{array}$ & $\mathrm{mg} / \mathrm{L}$ & $<2$ & $<2$ & $<2$ & $<2$ & $<2$ & $<2$ & & 2 & 7 \\
\hline $\begin{array}{l}\text { Suspended solids, } \\
\text { total }\end{array}$ & $\mathrm{mg} / \mathrm{L}$ & $<2$ & $<2$ & $<2$ & $<2$ & $<2$ & $<2$ & & 2 & 7 \\
\hline Volatile solids, total & $\mathrm{mg} / \mathrm{L}$ & $<2$ & $<2$ & $<2$ & $<2$ & $<2$ & $<2$ & & 2 & 7 \\
\hline Dissolved solids & $\mathrm{mg} / \mathrm{L}$ & $<50$ & $<50$ & $<50$ & $<50$ & $<50$ & $<50$ & & 50 & 167 \\
\hline Phosphorus, total & $\mathrm{mg} / \mathrm{L}$ & $<0.005$ & $<0.005$ & $<0.005$ & $<0.005$ & $<0.005$ & $<0.005$ & & 0.005 & 0.016 \\
\hline $\begin{array}{l}\text { Phosphorus, dis- } \\
\text { solved }\end{array}$ & $\mathrm{mg} / \mathrm{L}$ & $<0.005$ & $<0.005$ & $<0.005$ & $<0.005$ & $<0.005$ & $<0.005$ & & 0.005 & 0.016 \\
\hline Copper, dissolved & $\mu \mathrm{g} / \mathrm{L}$ & - & - & - & $<1$ & 2.3 & 1.2 & $<1$ & 1 & 3 \\
\hline $\begin{array}{l}\text { Zinc, total recover- } \\
\text { able }\end{array}$ & $\mu \mathrm{g} / \mathrm{L}$ & $<16$ & $<16$ & $<16$ & 21 & 3 & 11 & & 16 & 50 \\
\hline Zinc, dissolved & $\mu \mathrm{g} / \mathrm{L}$ & $<16$ & $<16$ & $<16$ & 2 & 3 & 2 & 3 & 16 & 50 \\
\hline $\begin{array}{l}\text { Calcium, total } \\
\text { recoverable }\end{array}$ & $\mathrm{mg} / \mathrm{L}$ & $<0.2$ & $<0.2$ & $<0.2$ & $<0.2$ & $<0.2$ & $<0.2$ & & 0.02 & 0.07 \\
\hline $\begin{array}{l}\text { Magnesium, total } \\
\text { recoverable }\end{array}$ & $\mathrm{mg} / \mathrm{L}$ & $<0.2$ & $<0.2$ & $<0.2$ & $<0.2$ & $<0.2$ & $<0.2$ & & 0.03 & 0.07 \\
\hline
\end{tabular}


Appendix 3. Relative percent difference for concentrations of selected water-quality constituents in field-replicate samples collected at inlet and outlet of hydrodynamic-settling device in Madison, Wisconsin, April and June 2006.

[Target, minimum criteria for acceptance of quality-control sample data without qualification; \%, percent; Rep, replicate; RPD, relative percent difference; $\mathrm{mg} / \mathrm{L}$, milligrams per liter; $\mu \mathrm{g} / \mathrm{L}$, micrograms per liter; - , no sample processed]

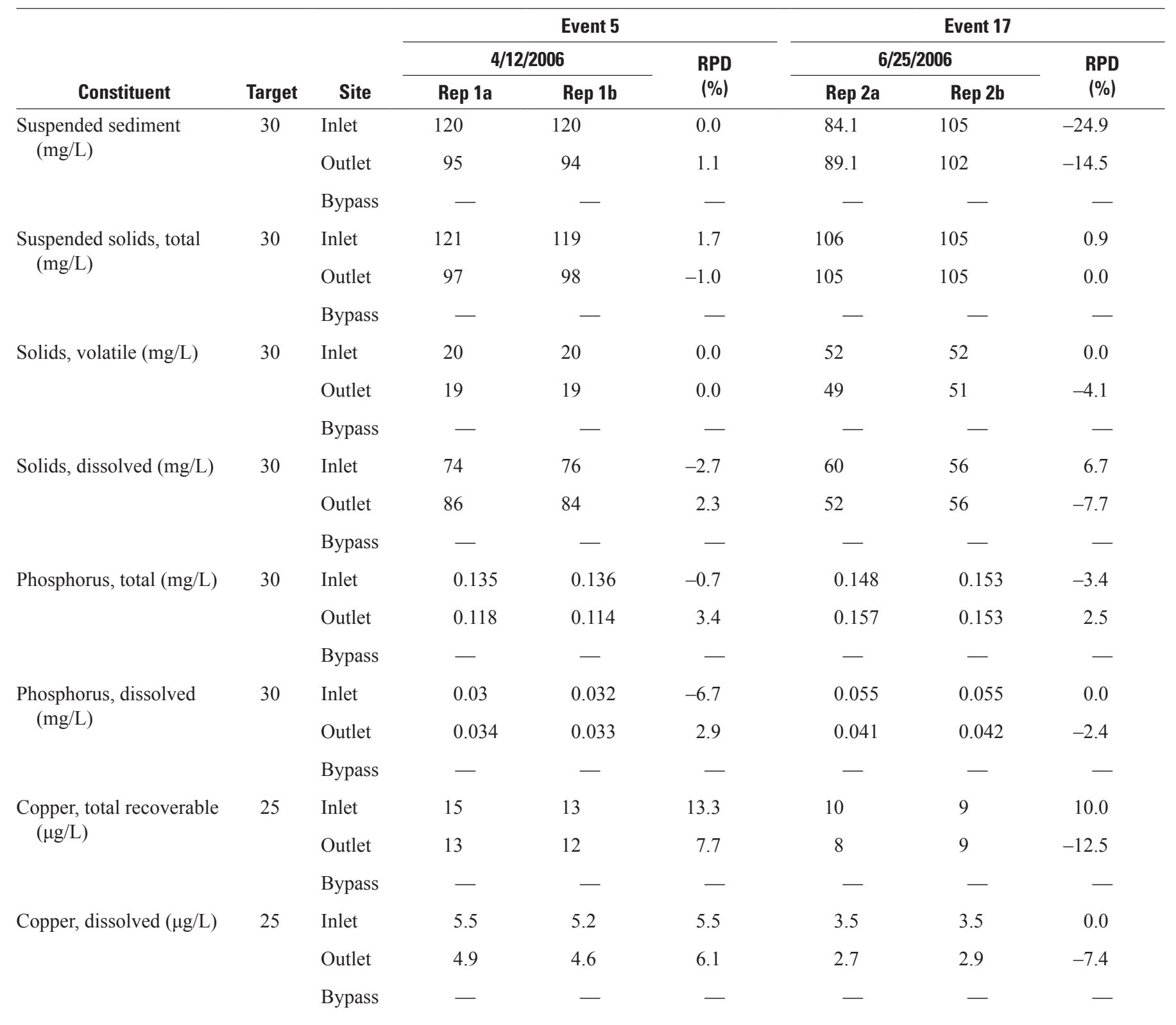


Appendix 3. Relative percent difference for concentrations of selected water-quality constituents in field-replicate samples collected at inlet and outlet of hydrodynamic-settling device in Madison, Wisconsin, April and June 2006. - Continued

[Target, minimum criteria for acceptance of quality-control sample data without qualification; \%, percent; Rep, replicate; RPD, relative percent difference; $\mathrm{mg} / \mathrm{L}$, milligrams per liter; $\mu \mathrm{g} / \mathrm{L}$, micrograms per liter; —, no sample processed]

\begin{tabular}{|c|c|c|c|c|c|c|c|c|}
\hline \multirow[b]{3}{*}{ Constituent } & \multirow[b]{3}{*}{ Target } & \multirow[b]{3}{*}{ Site } & \multicolumn{3}{|c|}{ Event 5} & \multicolumn{3}{|c|}{ Event 17} \\
\hline & & & \multicolumn{2}{|c|}{ 4/12/2006 } & \multirow{2}{*}{$\begin{array}{l}\text { RPD } \\
(\%)\end{array}$} & \multicolumn{2}{|c|}{$6 / 25 / 2006$} & \multirow{2}{*}{$\begin{array}{l}\text { RPD } \\
(\%)\end{array}$} \\
\hline & & & Rep 1a & Rep 1b & & Rep 2a & Rep 2b & \\
\hline \multirow{3}{*}{$\begin{array}{l}\text { Zinc, total recoverable } \\
\qquad(\mu \mathrm{g} / \mathrm{L})\end{array}$} & \multirow[t]{3}{*}{25} & Inlet & 36 & 38 & -5.6 & 47 & 49 & -4.3 \\
\hline & & Outlet & 34 & 33 & 2.9 & 48 & 46 & 4.2 \\
\hline & & Bypass & - & - & - & - & - & - \\
\hline \multirow[t]{3}{*}{ Zinc, dissolved $(\mu \mathrm{g} / \mathrm{L})$} & \multirow[t]{3}{*}{25} & Inlet & 6 & 6 & 0.0 & 7 & 11 & -57.1 \\
\hline & & Outlet & 5 & 6 & -20.0 & 5 & 6 & -20.0 \\
\hline & & Bypass & - & - & - & - & - & - \\
\hline \multirow{3}{*}{$\begin{array}{l}\text { Calcium, total recoverable } \\
\quad(\mathrm{mg} / \mathrm{L})\end{array}$} & \multirow[t]{3}{*}{25} & Inlet & 16 & 16.7 & -4.4 & 9.6 & 9.7 & -1.0 \\
\hline & & Outlet & 16 & 15.7 & 3.7 & 9.8 & 9.4 & 4.1 \\
\hline & & Bypass & - & - & - & - & - & - \\
\hline \multirow{3}{*}{$\begin{array}{l}\text { Magnesium, total recover- } \\
\text { able }(\mathrm{mg} / \mathrm{L})\end{array}$} & \multirow[t]{3}{*}{25} & Inlet & 7 & 7.2 & -4.3 & 3.5 & 3.6 & -2.9 \\
\hline & & Outlet & 7 & 6.4 & 4.5 & 3.7 & 3.5 & 5.4 \\
\hline & & Bypass & - & - & - & - & - & - \\
\hline \multirow{3}{*}{$\begin{array}{l}\text { Calculated hardness } \\
(\mathrm{mg} / \mathrm{L})\end{array}$} & \multirow[t]{3}{*}{25} & Inlet & 69 & 71.4 & -4.1 & 38.3 & 39.2 & -2.3 \\
\hline & & Outlet & 68 & 65.5 & 3.7 & 39.7 & 38 & 4.3 \\
\hline & & Bypass & - & - & - & - & - & - \\
\hline
\end{tabular}




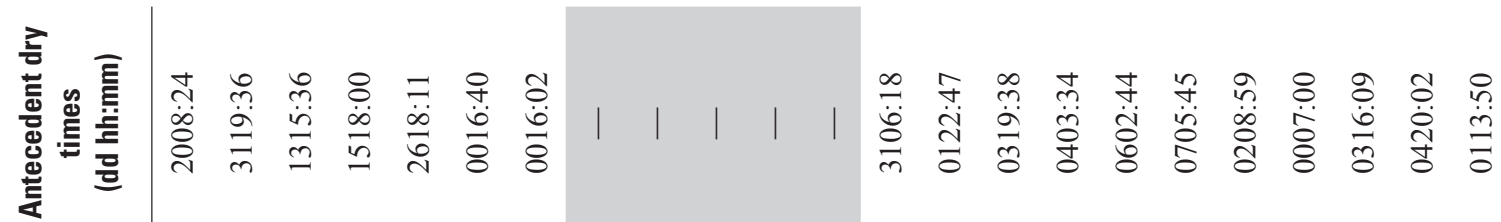

莺高焉 崖

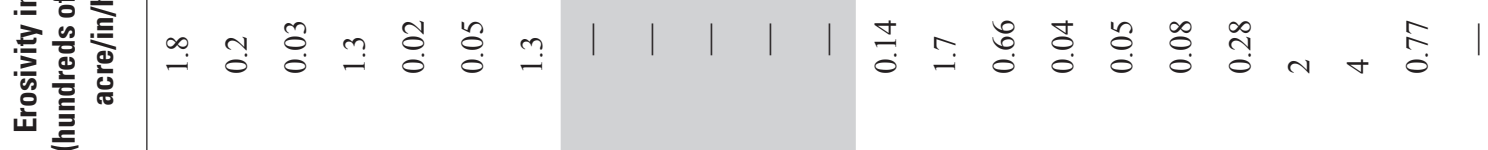

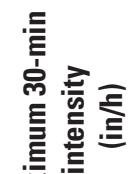

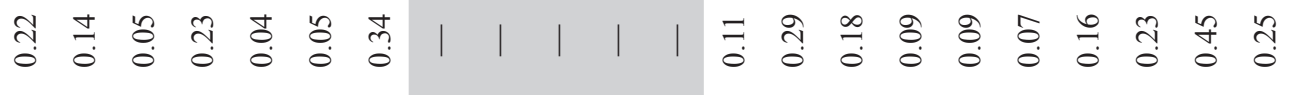

高

高

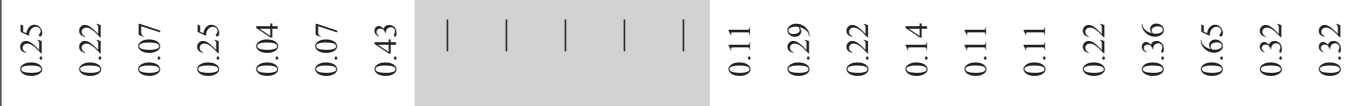

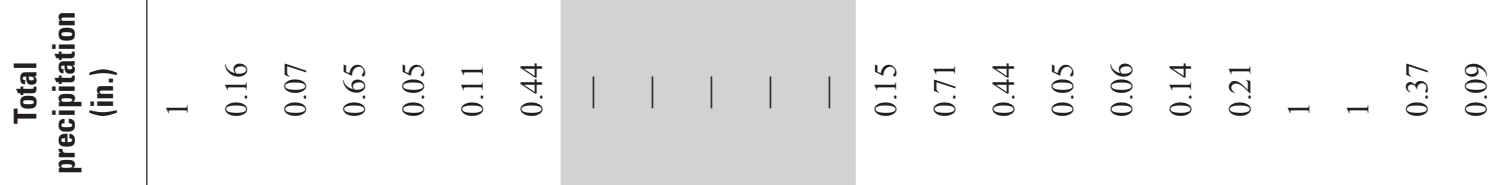

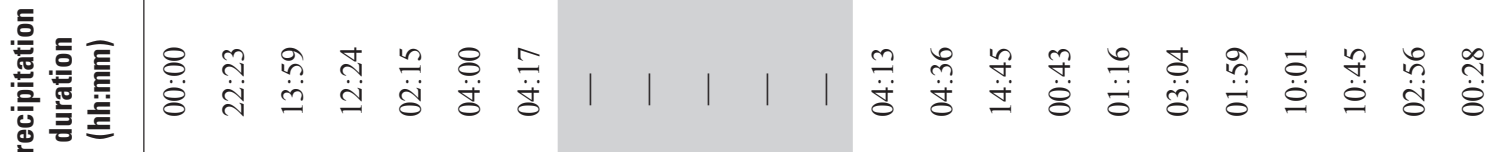

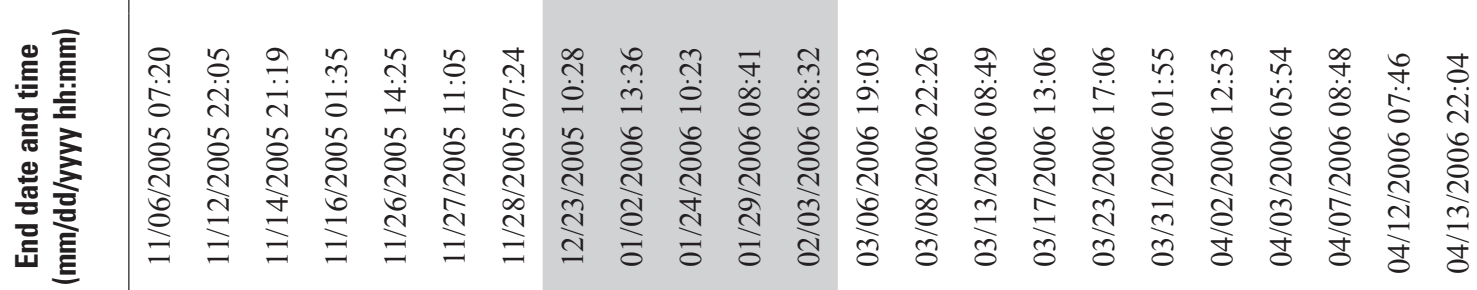

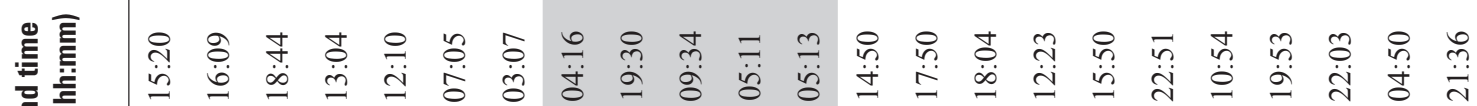

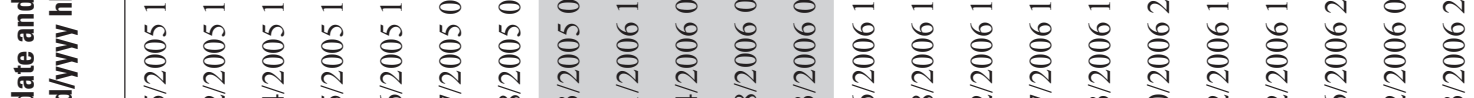
क娄 


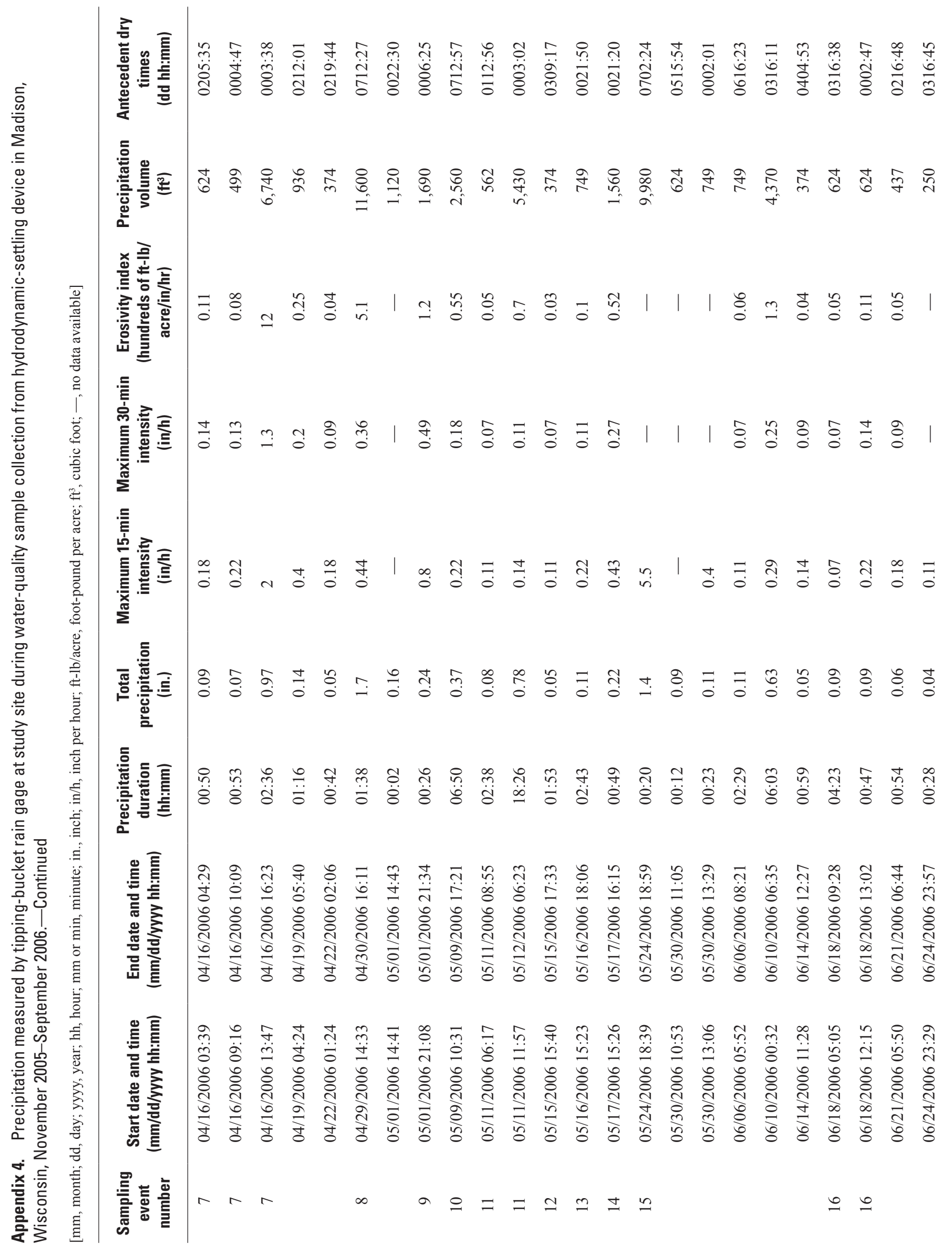




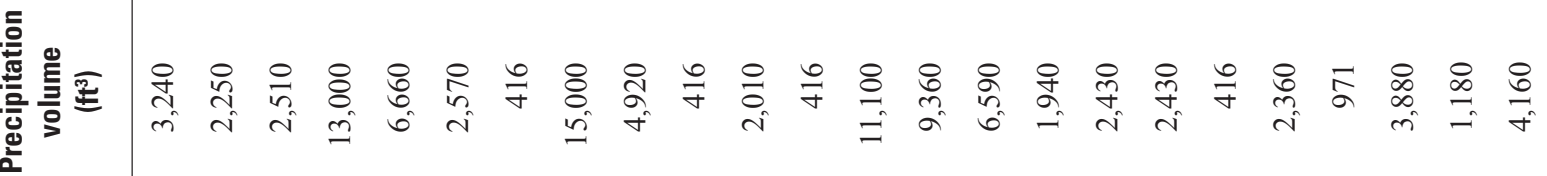
压

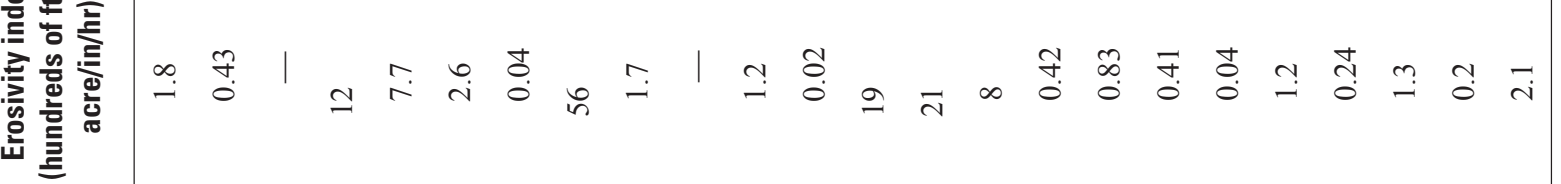
童高

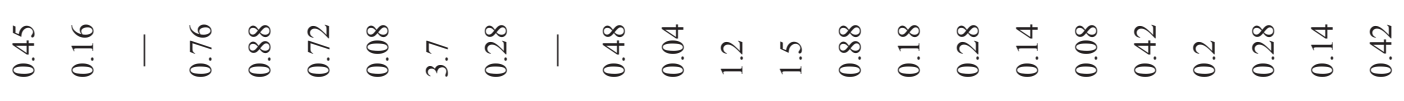
高高

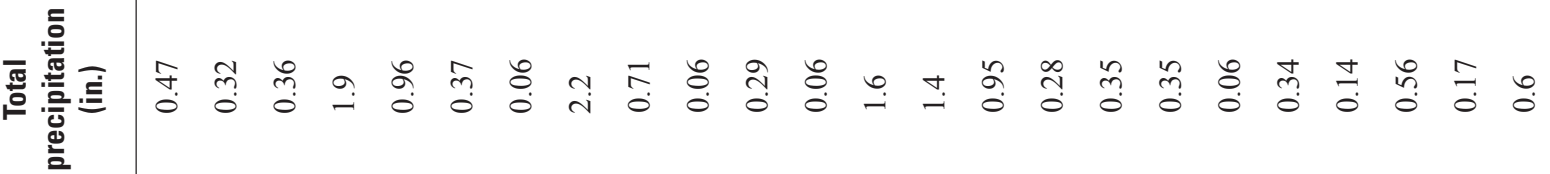

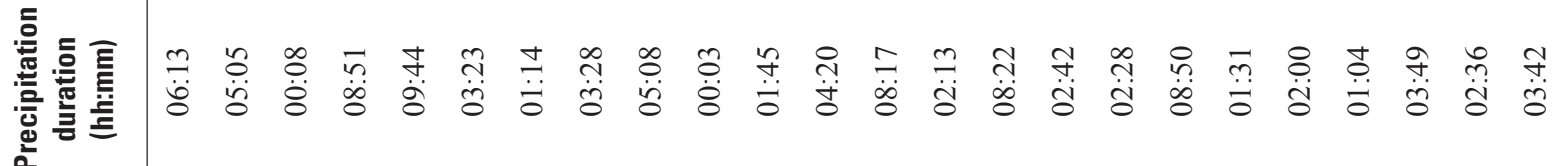

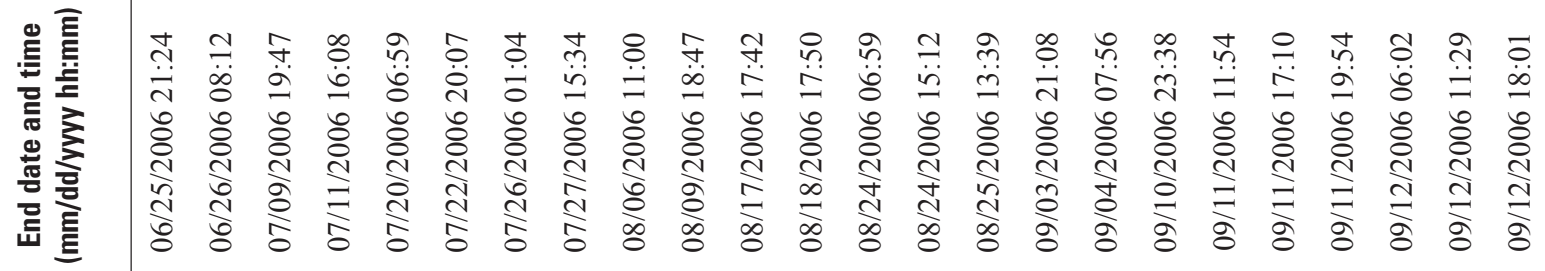

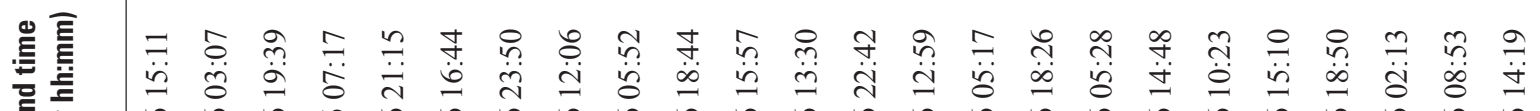
帘 焉严

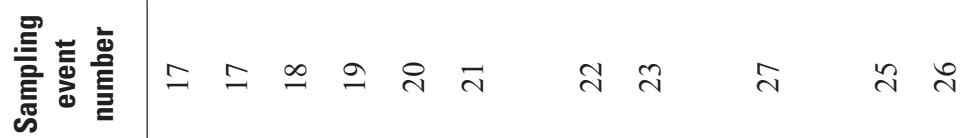




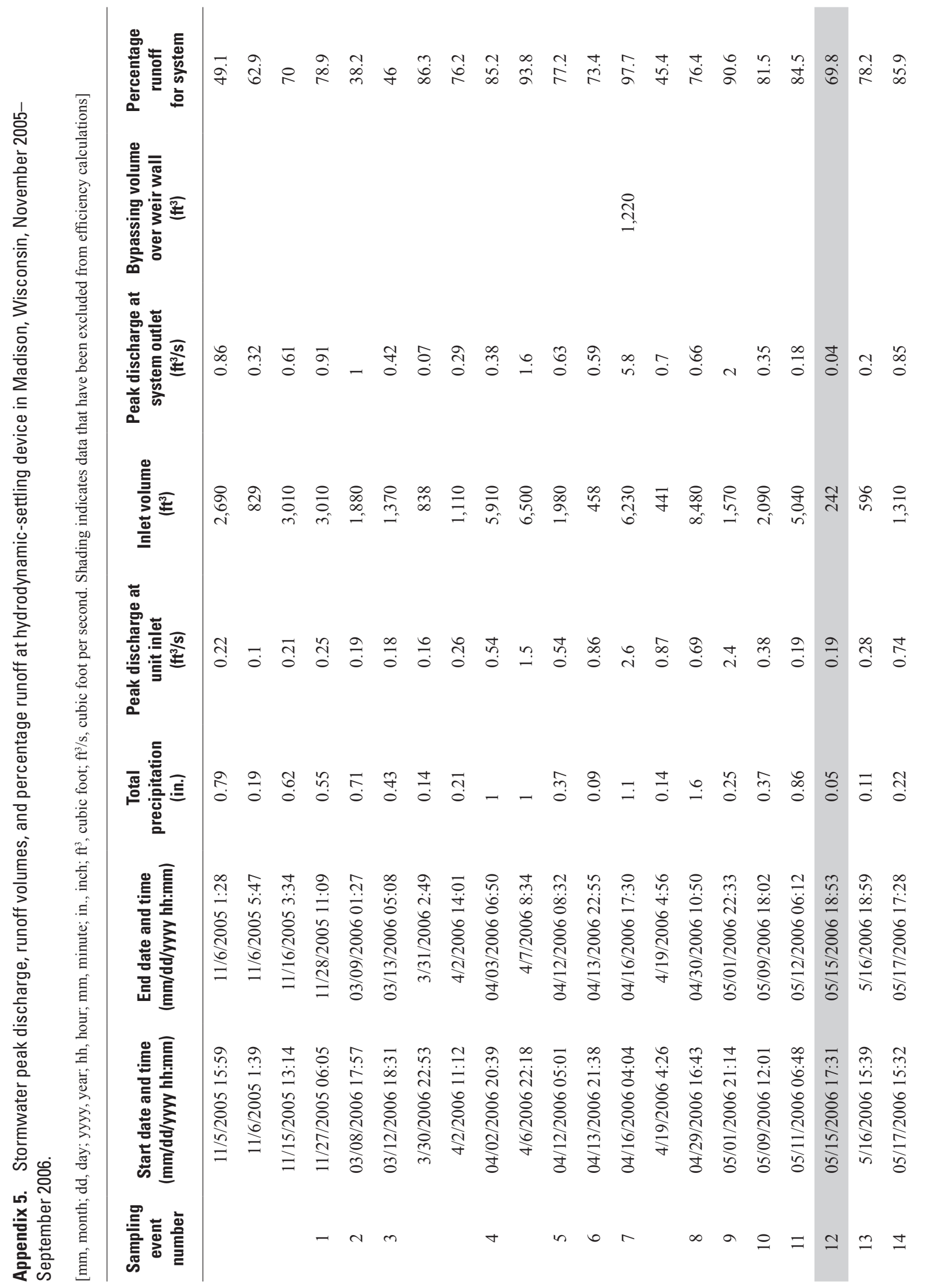




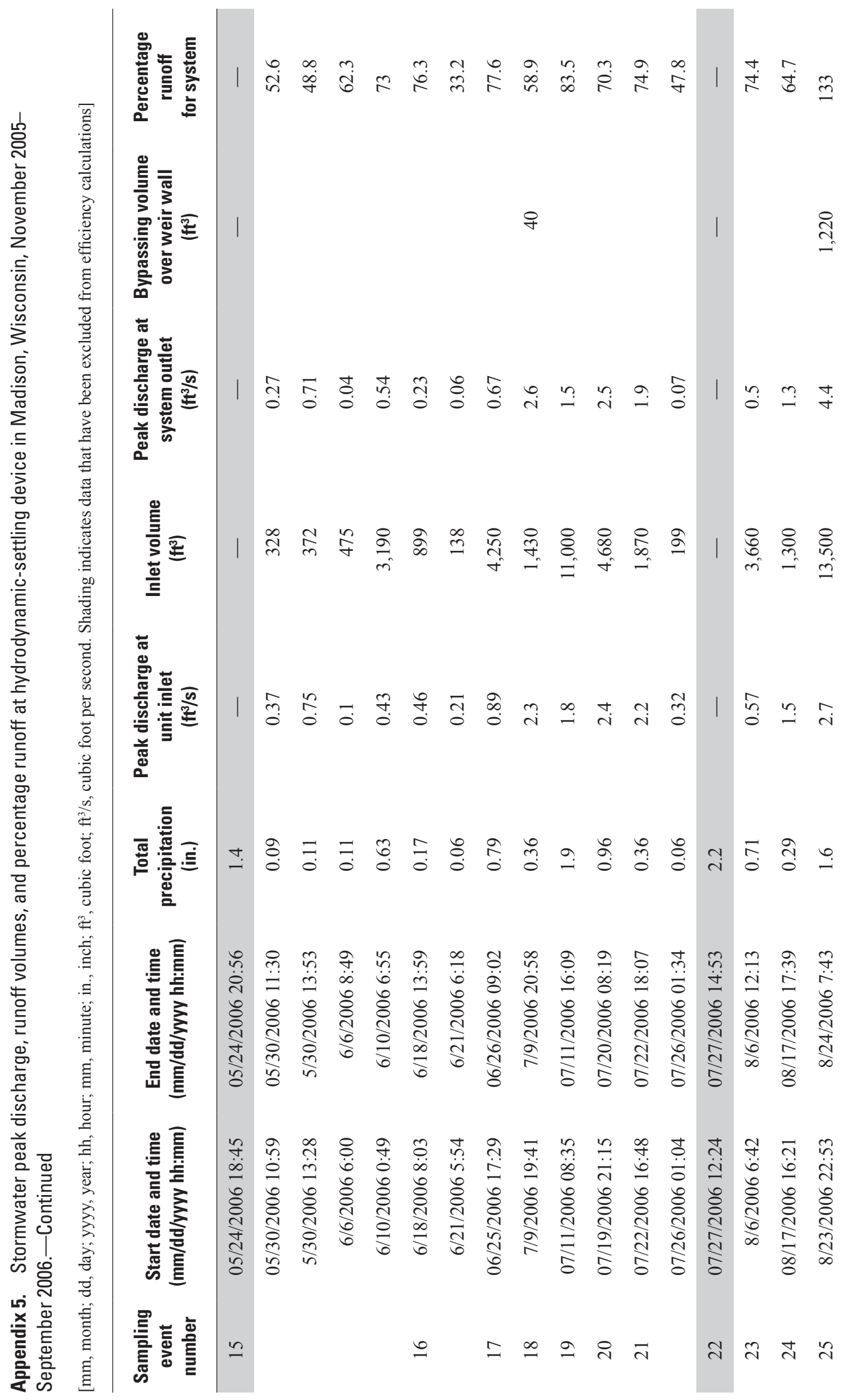




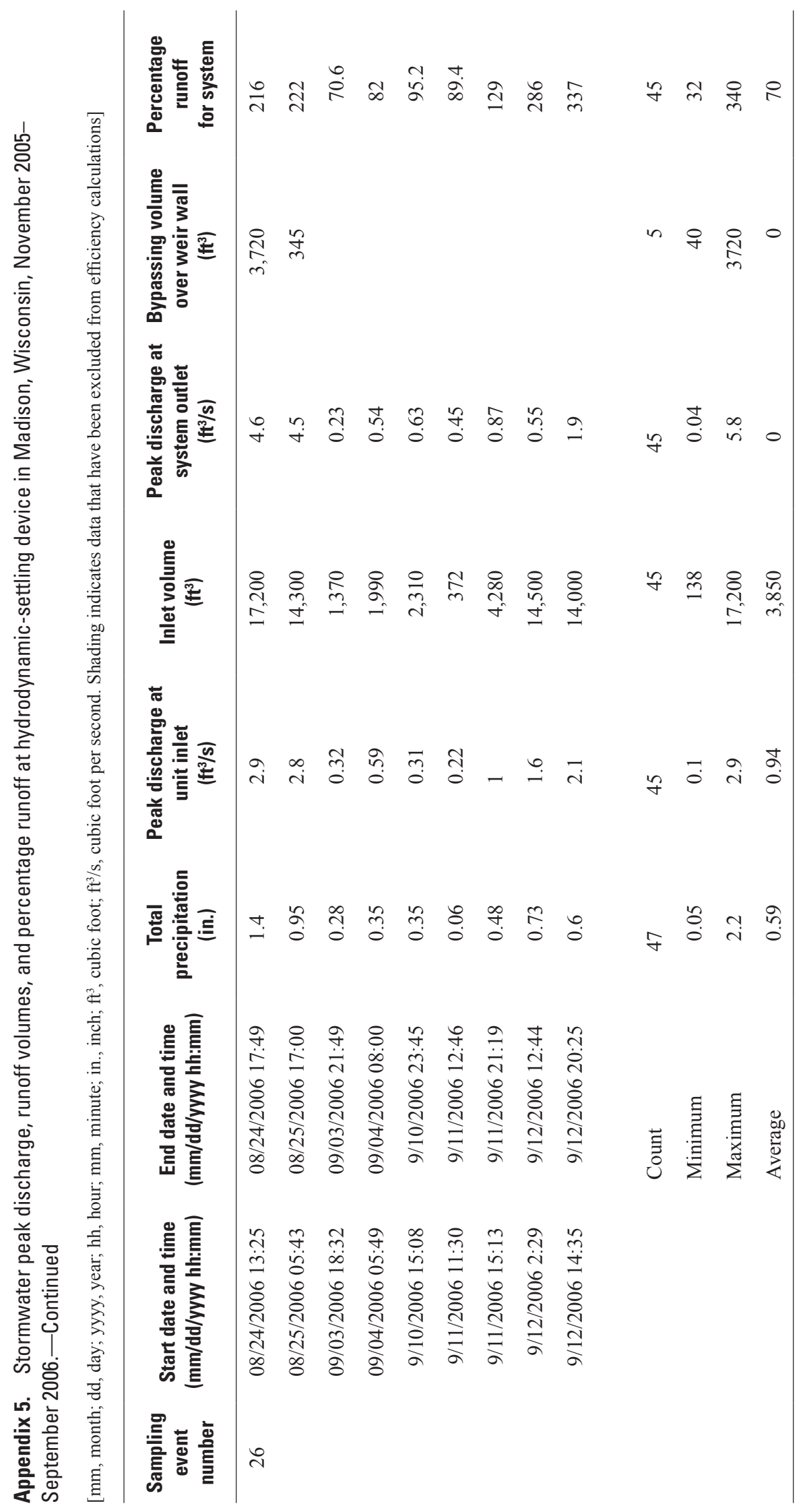


Appendix 6. Concentrations of suspended sediment, adjusted suspended solids, volatile solids, and dissolved solids in stormwater samples collected at inlet, outlet, and bypass of hydrodynamic-settling device in Madison, Wisconsin, Nobember 2005-August 2006.

[All data are in milligrams per liter; - , no sample processed; <, less than]

\begin{tabular}{|c|c|c|c|c|c|c|c|c|c|c|c|c|c|c|}
\hline \multirow{2}{*}{$\begin{array}{c}\text { Sampling date } \\
\text { (month/day/year) }\end{array}$} & \multirow{2}{*}{$\begin{array}{c}\text { Sampling } \\
\text { event } \\
\text { number }\end{array}$} & \multicolumn{3}{|c|}{ Suspended sediment } & \multicolumn{3}{|c|}{$\begin{array}{l}\text { Suspended solids, } \\
\text { total adjusted }\end{array}$} & \multicolumn{3}{|c|}{ Solids, volatile } & \multicolumn{3}{|c|}{ Solids, dissolved } & \multirow{2}{*}{$\begin{array}{c}\begin{array}{c}\text { Samples } \\
\text { sieved }\end{array} \\
\text { In/Out/Bypass }\end{array}$} \\
\hline & & Inlet & Outlet & Bypass & Inlet & Outlet & Bypass & Inlet & Outlet & Bypass & Inlet & Outlet & Bypass & \\
\hline $11 / 27 / 2005$ & 1 & 8 & 8 & - & 7 & 8 & - & - & - & - & 114 & 128 & - & Yes/No \\
\hline 03/08/2006 & 2 & 127 & 166 & - & 130 & 147 & - & - & - & - & 260 & 238 & - & Yes/No \\
\hline $03 / 12 / 2006$ & 3 & 64 & 52 & - & 61 & 52 & - & - & - & - & 192 & 86 & - & Yes/No \\
\hline $04 / 02 / 2006$ & 4 & 58 & 36 & - & 60 & 36 & - & - & - & - & 96 & 84 & - & Yes/No \\
\hline $04 / 12 / 2006$ & 5 & 120 & 95 & - & 124 & 97 & - & - & - & - & 74 & 86 & - & Yes/No \\
\hline $04 / 13 / 2006$ & 6 & 419 & 538 & - & 398 & 545 & - & 66 & 79 & - & 182 & 216 & - & $\mathrm{No} / \mathrm{No}$ \\
\hline $04 / 16 / 2006$ & 7 & 270 & 190 & 1,006 & 191 & 188 & 527 & - & - & - & 62 & 94 & $<50$ & $\mathrm{Yes} / \mathrm{No} / \mathrm{Yes}$ \\
\hline 04/29/2006 & 8 & 35 & 30 & - & 35 & 30 & - & 22 & 18 & - & 54 & 56 & - & $\mathrm{No} / \mathrm{No}$ \\
\hline 05/01/2006 & 9 & 165 & 202 & - & 144 & 217 & - & 47 & 69 & - & $<50$ & 64 & - & No/No \\
\hline 05/09/2006 & 10 & 22 & 21 & - & 23 & 24 & - & 12 & 11 & - & 74 & 52 & - & No/No \\
\hline $05 / 11 / 2006$ & 11 & 25 & 22 & - & 24 & 19 & - & 16 & 13 & - & 88 & 60 & - & No/No \\
\hline $05 / 15 / 2006$ & 12 & - & - & - & - & - & - & - & - & - & - & - & - & \\
\hline 05/16/2006 & 13 & 58 & 61 & - & 60 & 65 & - & 29 & 28 & - & 122 & - & - & No/No \\
\hline 05/17/2006 & 14 & 156 & 143 & - & 159 & 153 & - & 70 & 61 & - & 58 & 66 & - & No/No \\
\hline $05 / 24 / 2006$ & 15 & - & - & - & - & - & - & - & - & - & - & - & - & \\
\hline 06/18/2006 & 16 & 57 & 45 & - & 61 & 46 & - & 24 & 15 & - & 124 & 180 & - & No/No \\
\hline $06 / 25 / 2006$ & 17 & 104 & 104 & - & 106 & 105 & - & 52 & 49 & - & 60 & 52 & - & No/No \\
\hline 07/09/2006 & 18 & 450 & 662 & - & 371 & 584 & - & - & - & - & 80 & 72 & - & Yes/Yes \\
\hline $07 / 11 / 2006$ & 19 & 57 & 37 & - & 35 & 38 & - & 9 & 10 & - & $<50$ & $<50$ & - & $\mathrm{No} / \mathrm{No}$ \\
\hline 07/19/2006 & 20 & 128 & 137 & - & 81 & 120 & - & 20 & 30 & - & 52 & 137 & - & No/No \\
\hline $07 / 22 / 2006$ & 21 & 116 & 127 & - & 103 & 119 & - & 21 & 24 & - & $<50$ & $<50$ & - & $\mathrm{No} / \mathrm{No}$ \\
\hline $07 / 27 / 2006$ & 22 & - & - & - & - & - & - & - & - & - & - & - & - & \\
\hline 08/06/2006 & 23 & 59 & 37 & - & 51 & 37 & - & - & - & - & $<50$ & 58 & - & $\mathrm{No} / \mathrm{No}$ \\
\hline 08/17/2006 & 24 & 705 & 211 & - & 332 & 207 & - & - & - & - & 78 & 98 & - & Yes/No \\
\hline $08 / 23 / 2006$ & 25 & 527 & 327 & 476 & 349 & 349 & 314 & - & - & - & 136 & 112 & 90 & Yes/Yes/Yes \\
\hline \multirow[t]{7}{*}{$08 / 24 / 2006$} & 26 & 624 & 285 & 494 & 395 & 292 & 301 & - & - & - & 226 & 222 & 170 & $\mathrm{Yes} / \mathrm{No} / \mathrm{Yes}$ \\
\hline & Count & 23 & 23 & 3 & 23 & 23 & 3 & 12 & 12 & - & 23 & 22 & 3 & \\
\hline & Geomean & 107 & 90 & 618 & 92 & 89 & 368 & 27 & 27 & - & 99 & 95 & 124 & \\
\hline & Median & 116 & 104 & 494 & 103 & 105 & 314 & 23 & 26 & - & 88 & 86 & 130 & \\
\hline & Average & 189 & 154 & 659 & 144 & 151 & 381 & 32 & 34 & - & 112 & 108 & 130 & \\
\hline & Maximum & 705 & 662 & 1,006 & 398 & 584 & 527 & 70 & 79 & 0 & 260 & 238 & 0 & \\
\hline & Minimum & 8 & 8 & 476 & 7 & 8 & 301 & 9 & 10 & 0 & $<50$ & $<50$ & $<50$ & \\
\hline
\end{tabular}


Appendix 7. Concentrations of selected water-quality constituents and physical properties in stormwater samples collected at inlet, outlet, and bypass of hydrodynamic-settling device in Madison, Wisconsin, November 2005-September 2006.

$[\mathrm{mg} / \mathrm{L}$, milligrams per liter; $\mu \mathrm{g} / \mathrm{L}$, micrograms per liter; >, greater than; - , no sample processed. Shading indicates data that have been excluded from efficiency calculations]

\begin{tabular}{|c|c|c|c|c|c|c|c|c|c|c|c|c|c|c|c|}
\hline \multirow{2}{*}{$\begin{array}{c}\text { Sampling } \\
\text { event } \\
\text { number }\end{array}$} & \multicolumn{3}{|c|}{$\begin{array}{l}\text { Phosphorus, total } \\
\text { (mg/L) }\end{array}$} & \multicolumn{3}{|c|}{$\begin{array}{l}\text { Phosphorus, dissolved } \\
\text { (mg/L) }\end{array}$} & \multicolumn{3}{|c|}{$\begin{array}{l}\text { Copper, total recoverable } \\
(\mu \mathrm{g} / \mathrm{L})\end{array}$} & \multicolumn{3}{|c|}{$\begin{array}{l}\text { Copper, dissolved } \\
(\mu \mathrm{g} / \mathrm{L})\end{array}$} & \multicolumn{3}{|c|}{$\begin{array}{l}\text { Zinc, total recoverable } \\
(\mu \mathrm{g} / \mathrm{L})\end{array}$} \\
\hline & Inlet & Outlet & Bypass & Inlet & Outlet & Bypass & Inlet & Outlet & Bypass & Inlet & Outlet & Bypass & Inlet & Outlet & Bypass \\
\hline 1 & 0.070 & 0.13 & - & 0.05 & 0.07 & - & - & - & - & - & - & - & - & - & - \\
\hline 2 & 0.18 & 0.23 & - & 0.04 & 0.03 & - & 16 & 25 & - & 4.7 & 5.1 & - & 46 & 66 & - \\
\hline 3 & 0.10 & 0.09 & - & 0.03 & 0.03 & - & 10 & 10 & - & 4.7 & 3.1 & - & 21 & 24 & - \\
\hline 4 & 0.09 & 0.08 & - & 0.03 & 0.03 & - & 7 & 6 & - & - & - & - & 22 & 17 & - \\
\hline 5 & 0.14 & 0.12 & - & 0.03 & 0.03 & - & 15 & 13 & - & 5.5 & 4.9 & - & 36 & 34 & - \\
\hline 6 & - & - & - & - & - & - & - & - & - & - & - & - & - & - & - \\
\hline 7 & 0.22 & 0.23 & 0.40 & 0.05 & 0.04 & 0.04 & 22 & 21 & 16 & 3.6 & 3.7 & 1.8 & 45 & 48 & 136 \\
\hline 8 & 0.25 & 0.09 & - & 0.03 & 0.05 & - & 7 & 6 & - & 2.8 & 3.7 & - & 19 & 21 & - \\
\hline 9 & 0.16 & 0.19 & - & 0.03 & 0.03 & - & 16 & 20 & - & 2.1 & 1.6 & - & 45 & 62 & - \\
\hline 10 & 0.11 & 0.10 & - & 0.05 & 0.04 & - & 9 & 15 & - & 6.9 & 9.9 & - & 23 & 30 & - \\
\hline 11 & 0.17 & 0.17 & - & 0.10 & 0.10 & - & 6 & 6 & - & 4.8 & 4.4 & - & 18 & 18 & - \\
\hline 12 & - & - & - & - & - & - & - & - & - & - & - & - & - & - & - \\
\hline 13 & - & - & - & - & - & - & - & - & - & - & - & - & - & - & - \\
\hline 14 & 0.23 & 0.23 & - & 0.03 & 0.03 & - & 15 & 14 & - & 4.2 & 3.5 & - & 64 & 55 & - \\
\hline 15 & - & - & - & - & - & - & - & - & - & - & - & - & - & - & - \\
\hline 16 & - & - & - & - & - & - & - & - & - & - & - & - & - & - & - \\
\hline 17 & 0.15 & 0.31 & - & 0.06 & 0.08 & - & 10 & 17 & - & 3.5 & 5.6 & - & 47 & 94 & - \\
\hline 18 & 0.29 & 0.36 & - & 0.07 & 0.06 & - & 29 & 36 & - & 7.0 & 6.2 & - & 100 & 129 & - \\
\hline 19 & 0.09 & 0.10 & - & 0.06 & 0.05 & - & 6 & 5 & - & 3.9 & 4.0 & - & 17 & 18 & - \\
\hline 20 & 0.12 & 0.14 & - & 0.04 & 0.04 & - & 9 & 10 & - & 4.6 & 7.5 & - & 40 & 50 & - \\
\hline 21 & 0.12 & 0.12 & - & 0.04 & 0.01 & - & 14 & 12 & - & 4.0 & 5.9 & - & 36 & 41 & - \\
\hline 22 & - & - & - & - & - & - & - & - & - & - & - & - & - & - & - \\
\hline 23 & 0.16 & 0.14 & - & 0.07 & 0.06 & - & 8 & 9 & - & 5.0 & 4.0 & - & 36 & 31 & - \\
\hline 24 & 0.34 & 0.30 & - & 0.09 & 0.06 & - & 25 & 28 & - & 8.0 & 6.0 & - & 102 & 128 & - \\
\hline 25 & 1.7 & 1.4 & 1.1 & 1.13 & .87 & 0.60 & 37 & 34 & 40 & 9.0 & 8.0 & 7.0 & 95 & 99 & 118 \\
\hline 26 & - & - & - & - & - & - & - & - & - & - & - & - & - & - & - \\
\hline Count & 19 & 19 & 2 & 19 & 19 & 2 & 18 & 18 & 2 & 17 & 17 & 2 & 18 & 18 & 2 \\
\hline Geomean & 0.17 & 0.17 & 0.66 & 0.05 & 0.05 & 0.15 & 12 & 13 & 25 & 4.7 & 4.7 & 3.5 & 38 & 43 & 127 \\
\hline Median & 0.16 & 0.14 & 0.75 & 0.05 & 0.04 & 0.32 & 12 & 14 & 28 & 4.7 & 4.9 & 4.4 & 38 & 45 & 127 \\
\hline Average & 0.25 & 0.24 & 0.75 & 0.11 & 0.09 & 0.32 & 15 & 16 & 28 & 5.0 & 5.1 & 4.4 & 45 & 54 & 127 \\
\hline Maximum & 1.7 & 1.4 & 1.1 & 1.1 & 0.87 & 0.60 & 37 & 36 & 40 & 9.0 & 9.9 & 7.0 & 102 & 129 & 136 \\
\hline Minimum & .07 & 0.08 & 0.40 & 0.03 & 0.01 & .04 & 6 & 5 & 16 & 2.1 & 1.6 & 1.8 & 17 & 17 & 118 \\
\hline
\end{tabular}


Appendix 7. Concentrations of selected water-quality constituents and physical properties in stormwater samples collected at inlet, outlet, and bypass of hydrodynamic-settling device in Madison, Wisconsin, November 2005-September 2006.-Continued

$[\mathrm{mg} / \mathrm{L}$, milligrams per liter; $\mu \mathrm{g} / \mathrm{L}$, micrograms per liter; >, greater than; - , no sample processed. Shading indicates data that have been excluded from efficiency calculations]

\begin{tabular}{|c|c|c|c|c|c|c|c|c|c|c|c|c|}
\hline \multirow{2}{*}{$\begin{array}{c}\text { Sampling } \\
\text { event } \\
\text { number }\end{array}$} & \multicolumn{3}{|c|}{$\begin{array}{l}\text { Zinc, dissolved } \\
(\mu \mathrm{g} / \mathrm{L})\end{array}$} & \multicolumn{3}{|c|}{$\begin{array}{l}\text { Calcium, total recoverable } \\
\text { (mg/L) }\end{array}$} & \multicolumn{3}{|c|}{$\begin{array}{l}\text { Magnesium, total recoverable } \\
\text { (mg/L) }\end{array}$} & \multicolumn{3}{|c|}{$\begin{array}{l}\text { Calculated hardness } \\
\qquad(\mathrm{mg} / \mathrm{L})\end{array}$} \\
\hline & Inlet & Outlet & Bypass & Inlet & Outlet & Bypass & Inlet & Outlet & Bypass & Inlet & Outlet & Bypass \\
\hline 1 & - & - & - & 11 & 16 & - & 4 & 5 & - & 43 & 60 & - \\
\hline 2 & $>16$ & $>16$ & - & 22 & 22 & - & 11 & 11 & - & 101 & 99 & - \\
\hline 3 & $>16$ & $>16$ & - & 18 & 11 & - & 9 & 5 & - & 80 & 46 & - \\
\hline 4 & - & - & - & 12 & 9 & - & 5 & 4 & - & 50 & 38 & - \\
\hline 5 & 6 & 5 & - & 16 & 16 & - & 7 & 7 & - & 69 & 68 & - \\
\hline 6 & - & - & - & - & - & - & - & - & - & - & - & - \\
\hline 7 & 4 & 4 & 5 & 17 & 20 & 16 & 8 & 10 & 6 & 77 & 89 & 67 \\
\hline 8 & 11 & 8 & - & 8 & 8 & - & 3 & 2 & - & 30 & 29 & - \\
\hline 9 & 5 & 5 & - & 14 & 18 & - & 6 & 8 & - & 61 & 78 & - \\
\hline 10 & 11 & 10 & - & 9 & 7 & - & 3 & 2 & - & 34 & 27 & - \\
\hline 11 & 10 & 10 & - & 9 & 8 & - & 3 & 3 & - & 35 & 30 & - \\
\hline 12 & - & - & - & - & - & - & - & - & - & - & - & - \\
\hline 13 & - & - & - & - & - & - & - & - & - & - & - & - \\
\hline 14 & 8 & 8 & - & 14 & 15 & - & 6 & 7 & - & 60 & 63 & - \\
\hline 15 & - & - & - & - & - & - & - & - & - & - & - & - \\
\hline 16 & - & - & - & - & - & - & - & - & - & - & - & - \\
\hline 17 & 7 & 11 & - & 10 & 19 & - & 4 & 7 & - & 38 & 40 & - \\
\hline 18 & 7 & 9 & - & 26 & 35 & - & 13 & 18 & - & 117 & 161 & - \\
\hline 19 & 5 & 5 & - & 5 & 5 & - & 2 & 2 & - & 21 & 22 & - \\
\hline 20 & 5 & 6 & - & 14 & 15 & - & 6 & 6 & - & 59 & 59 & - \\
\hline 21 & 3 & 5 & - & 11 & 13 & - & 5 & 6 & - & 48 & 55 & - \\
\hline 22 & - & - & - & - & - & - & - & - & - & - & - & - \\
\hline 23 & 12 & 11 & - & 8 & 8 & - & 3 & 3 & - & 30 & 29 & - \\
\hline 24 & 14 & 15 & - & 15 & 20 & - & 6 & 8 & - & 64 & 82 & - \\
\hline 25 & 24 & 21 & 20 & 19 & 22 & 23 & 9 & 10 & 10 & 84 & 97 & 99 \\
\hline 26 & - & - & - & - & - & - & - & - & - & - & - & - \\
\hline Count & 15 & 15 & 2 & 19 & 19 & 2 & 19 & 19 & 2 & 19 & 19 & 2 \\
\hline Geomean & 8 & 8 & 10 & 13 & 13 & 19 & 5 & 5 & 8 & 53 & 54 & 82 \\
\hline Median & 7 & 8 & 13 & 14 & 15 & 19 & 6 & 6 & 8 & 59 & 59 & 83 \\
\hline Average & 9 & 9 & 13 & 14 & 15 & 19 & 6 & 6 & 8 & 58 & 62 & 83 \\
\hline Maximum & 24 & 21 & 20 & 26 & 35 & 23 & 13 & 18 & 10 & 117 & 161 & 99 \\
\hline Minimum & 3 & 4 & 5 & 5.0 & 5.2 & 16 & 2 & 2 & 6 & 21 & 22 & 67 \\
\hline
\end{tabular}


Appendix 8. Mean concentrations of selected polycyclic aromatic hydrocarbons in stormwater samples collected at inlet and outlet of hydrodynamic-settling device in Madison, Wisconsin, November 2005-August 2006.

[All concentrations in micrograms per liter; PAH, polycyclic aromatic hydrocarbons; <, less than; - , no sample processed]

\begin{tabular}{|c|c|c|c|c|c|c|c|c|c|}
\hline $\begin{array}{c}\text { Sampling } \\
\text { event } \\
\text { number }\end{array}$ & $\begin{array}{c}\text { 2-Methyl- } \\
\text { naphtha- } \\
\text { lene }\end{array}$ & $\begin{array}{l}\text { 1-Methyl- } \\
\text { naphtha- } \\
\text { lene }\end{array}$ & $\begin{array}{c}\text { Acenaph- } \\
\text { thylene }\end{array}$ & $\begin{array}{c}\text { Acenaph- } \\
\text { thene }\end{array}$ & Anthracene & $\begin{array}{c}\text { Benzo }[b] \\
\text { fluoran- } \\
\text { thene }\end{array}$ & $\begin{array}{c}\text { Benzo }[k] \\
\text { fluoran- } \\
\text { thene }\end{array}$ & $\begin{array}{c}\text { Benzo[a] } \\
\text { pyrene }\end{array}$ & Chrysene \\
\hline \multicolumn{10}{|c|}{ Inlet } \\
\hline 1 & - & - & - & - & - & - & - & - & - \\
\hline 2 & - & - & - & - & - & - & - & - & - \\
\hline 3 & - & - & - & - & - & - & - & - & - \\
\hline 4 & - & - & - & - & - & - & - & - & - \\
\hline 5 & - & - & - & - & - & - & - & - & - \\
\hline 6 & - & - & - & - & - & - & - & - & - \\
\hline 7 & - & - & - & - & - & - & - & - & - \\
\hline 8 & $<0.049$ & $<0.064$ & $<0.11$ & $<0.064$ & $<0.031$ & $<0.13$ & $<0.12$ & $<0.16$ & 0.059 \\
\hline 9 & $<0.049$ & $<0.064$ & $<0.11$ & $<0.064$ & $<0.031$ & 0.23 & $<0.12$ & 0.16 & 0.2 \\
\hline 10 & $<0.049$ & $<0.064$ & $<0.11$ & $<0.064$ & $<0.031$ & $<0.13$ & $<0.12$ & $<0.16$ & 0.036 \\
\hline 11 & $<0.049$ & $<0.064$ & $<0.11$ & $<0.064$ & $<0.031$ & $<0.13$ & $<0.12$ & $<0.16$ & $<0.027$ \\
\hline 12 & - & - & - & - & - & - & - & - & - \\
\hline 13 & - & - & - & - & - & - & - & - & - \\
\hline 14 & $<0.049$ & $<0.064$ & $<0.11$ & $<0.064$ & 0.048 & 0.39 & 0.17 & 0.24 & 0.35 \\
\hline 15 & - & - & - & - & - & - & - & - & - \\
\hline 16 & - & - & - & - & - & - & - & - & - \\
\hline 17 & $<0.049$ & $<0.064$ & $<0.11$ & $<0.064$ & $<0.031$ & $<0.13$ & $<0.12$ & $<0.16$ & 0.11 \\
\hline 18 & - & - & - & - & - & - & - & - & - \\
\hline 19 & $<0.049$ & $<0.064$ & $<0.11$ & $<0.064$ & $<0.031$ & $<0.13$ & $<0.12$ & $<0.16$ & 0.04 \\
\hline 20 & - & - & - & - & - & - & - & - & - \\
\hline 21 & - & - & - & - & - & - & - & - & - \\
\hline 22 & - & - & - & - & - & - & - & - & - \\
\hline 23 & - & - & - & - & - & - & - & - & - \\
\hline 24 & - & - & - & - & - & - & - & - & - \\
\hline 25 & - & - & - & - & - & - & - & - & - \\
\hline 26 & - & - & - & - & - & - & - & - & - \\
\hline \multicolumn{10}{|c|}{ Outlet } \\
\hline
\end{tabular}


Appendix 8. Mean concentrations of selected polycyclic aromatic hydrocarbons in stormwater samples collected at inlet and outlet of hydrodynamic-settling device in Madison, Wisconsin, November 2005-August 2006. —Continued

[All concentrations in micrograms per liter; $\mathrm{PAH}$, polycyclic aromatic hydrocarbons; <, less than; —, no sample processed]

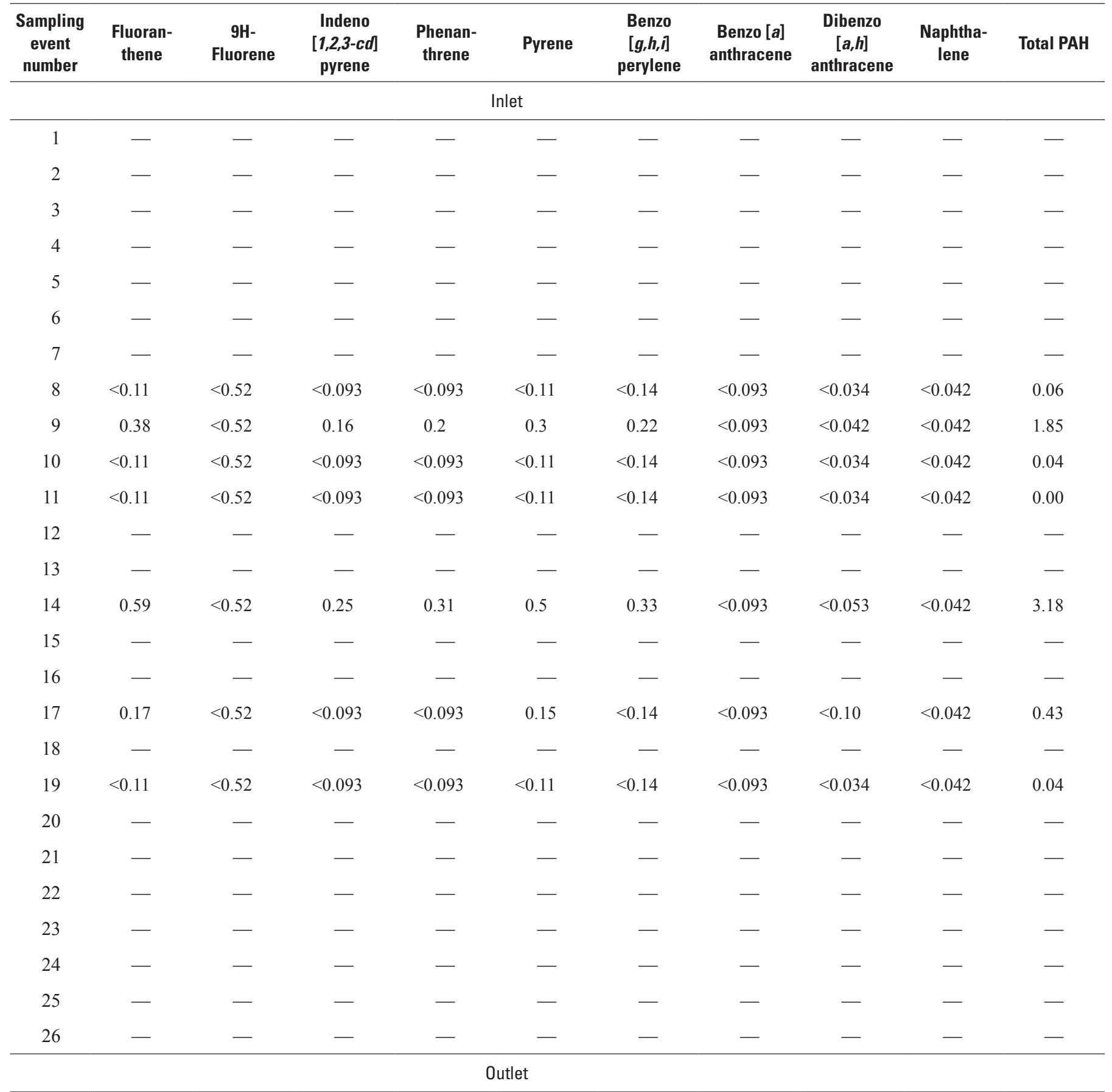


Appendix 8. Mean concentrations of selected polycyclic aromatic hydrocarbons in stormwater samples collected at inlet and outlet of hydrodynamic-settling device in Madison, Wisconsin, November 2005-August 2006._Continued

[All concentrations in micrograms per liter; PAH, polycyclic aromatic hydrocarbons; <, less than; —, no sample processed]

\begin{tabular}{|c|c|c|c|c|c|c|c|c|c|}
\hline $\begin{array}{c}\text { Sampling } \\
\text { event } \\
\text { number }\end{array}$ & $\begin{array}{c}\text { 2-Methyl- } \\
\text { naphtha- } \\
\text { lene }\end{array}$ & $\begin{array}{c}\text { 1-Methyl- } \\
\text { naphtha- } \\
\text { lene }\end{array}$ & $\begin{array}{l}\text { Acenaph- } \\
\text { thylene }\end{array}$ & $\begin{array}{c}\text { Acenaph- } \\
\text { thene }\end{array}$ & Anthracene & $\begin{array}{c}\text { Benzo }[b] \\
\text { fluoran- } \\
\text { thene }\end{array}$ & $\begin{array}{c}\text { Benzo[k] } \\
\text { fluoran- } \\
\text { thene }\end{array}$ & $\begin{array}{c}\text { Benzo[a] } \\
\text { pyrene }\end{array}$ & Chrysene \\
\hline \multicolumn{10}{|c|}{ Outlet } \\
\hline 7 & - & - & - & - & - & - & - & - & - \\
\hline 8 & $<0.049$ & $<0.064$ & $<0.11$ & $<0.064$ & $<0.031$ & $<0.13$ & $<0.12$ & $<0.16$ & 0.046 \\
\hline 9 & $<0.049$ & $<0.064$ & $<0.11$ & $<0.064$ & $<0.031$ & 0.32 & 0.15 & $<0.32$ & 0.29 \\
\hline 10 & $<0.049$ & $<0.064$ & $<0.11$ & $<0.064$ & $<0.031$ & $<0.13$ & $<0.12$ & $<0.16$ & 0.043 \\
\hline 11 & $<0.049$ & $<0.064$ & $<0.11$ & $<0.064$ & $<0.031$ & $<0.13$ & $<0.12$ & $<0.16$ & $<0.027$ \\
\hline 12 & - & - & - & - & - & - & - & - & - \\
\hline 13 & - & - & - & - & - & - & - & - & - \\
\hline 14 & $<0.049$ & $<0.064$ & $<0.11$ & $<0.064$ & 0.1 & 0.38 & 0.18 & 0.26 & 0.36 \\
\hline 15 & - & - & - & - & - & - & - & - & - \\
\hline 16 & - & - & - & - & - & - & - & - & - \\
\hline 17 & $<0.049$ & $<0.064$ & $<0.11$ & $<0.064$ & $<0.031$ & $<0.13$ & $<0.12$ & $<0.16$ & 0.12 \\
\hline 18 & - & - & - & - & - & - & - & - & - \\
\hline 19 & $<0.049$ & $<0.064$ & $<0.11$ & $<0.064$ & $<0.031$ & $<0.13$ & $<0.12$ & $<0.16$ & $<0.050$ \\
\hline 20 & - & - & - & - & - & - & - & - & - \\
\hline 21 & - & - & - & - & - & - & - & - & - \\
\hline 22 & - & - & - & - & - & - & - & - & - \\
\hline 23 & - & - & - & - & - & - & - & - & - \\
\hline 24 & - & - & - & - & - & - & - & - & - \\
\hline 25 & - & - & - & - & - & - & - & - & - \\
\hline 26 & - & - & - & - & - & - & - & - & - \\
\hline
\end{tabular}


Appendix 8. Mean concentrations of selected polycyclic aromatic hydrocarbons in stormwater samples collected at inlet and outlet of hydrodynamic-settling device in Madison, Wisconsin, November 2005-August 2006. - Continued

[All concentrations in micrograms per liter; PAH, polycyclic aromatic hydrocarbons; <, less than; —, no sample processed]

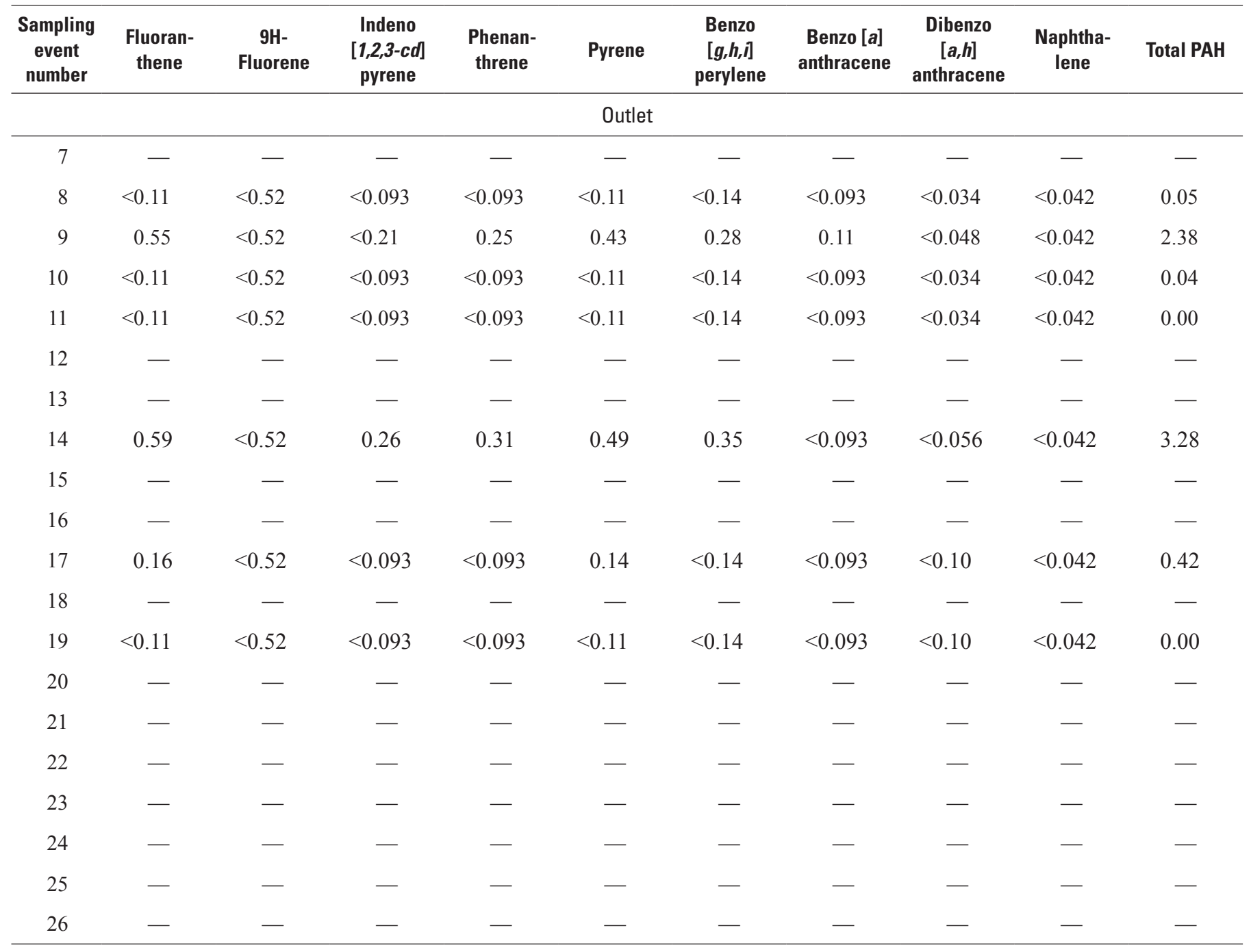


Appendix 9. Particle-size distributions in stormwater samples collected at inlet, outlet, and bypass of hydrodynamic-settling device in Madison, Wisconsin, November 2005-August 2006.

[All data are in percent by mass; $<$, less than; $\mu \mathrm{m}$, micrometer; - , no sample processed]

\begin{tabular}{|c|c|c|c|c|c|c|c|c|c|c|}
\hline \multirow{3}{*}{$\begin{array}{l}\text { Sampling date } \\
\text { (month/day/year) }\end{array}$} & \multirow{3}{*}{$\begin{array}{l}\text { Sampling } \\
\text { event } \\
\text { number }\end{array}$} & \multicolumn{9}{|c|}{ Particle size } \\
\hline & & \multicolumn{3}{|c|}{$<500 \mu \mathrm{m}$} & \multicolumn{3}{|c|}{$<250 \mu \mathrm{m}$} & \multicolumn{3}{|c|}{$<125 \mu \mathrm{m}$} \\
\hline & & Inlet & Outlet & Bypass & Inlet & Outlet & Bypass & Inlet & Outlet & Bypass \\
\hline $11 / 27 / 2005$ & 1 & 96 & 92 & - & 84 & 85 & - & 73 & 70 & - \\
\hline $03 / 08 / 2006$ & 2 & 100 & 100 & - & 99 & 97 & - & 95 & 96 & - \\
\hline $03 / 12 / 2006$ & 3 & 99 & 99 & - & 98 & 98 & - & 91 & 96 & - \\
\hline $04 / 02 / 2006$ & 4 & 99 & 99 & - & 98 & 98 & - & 96 & 95 & - \\
\hline $04 / 12 / 2006$ & 5 & 100 & 99 & - & 97 & 98 & - & 94 & 94 & - \\
\hline $04 / 13 / 2006$ & 6 & - & - & - & - & - & - & - & - & - \\
\hline $04 / 16 / 2006$ & 7 & 100 & 100 & 100 & 64 & 94 & 81 & 53 & 83 & 64 \\
\hline $04 / 29 / 2006$ & 8 & 98 & 98 & - & 84 & 87 & - & 66 & 66 & - \\
\hline 05/01/2006 & 9 & 100 & 98 & - & 94 & 91 & - & 79 & 71 & - \\
\hline $05 / 09 / 2006$ & 10 & 97 & 97 & - & 95 & 92 & - & 77 & 70 & - \\
\hline $05 / 11 / 2006$ & 11 & 93 & 98 & - & 81 & 77 & - & 66 & 62 & - \\
\hline $05 / 15 / 2006$ & 12 & - & - & - & - & - & - & - & - & - \\
\hline $05 / 16 / 2006$ & 13 & - & - & - & - & - & - & - & - & - \\
\hline $05 / 17 / 2006$ & 14 & 87 & 94 & - & 74 & 89 & - & 61 & 68 & - \\
\hline $05 / 24 / 2006$ & 15 & - & - & - & - & - & - & - & - & - \\
\hline $06 / 18 / 2006$ & 16 & 96 & 99 & - & 91 & 92 & - & 78 & 77 & - \\
\hline $06 / 25 / 2006$ & 17 & 93 & 97 & - & 80 & 85 & - & 61 & 67 & - \\
\hline $07 / 09 / 2006$ & 18 & 100 & 100 & - & 76 & 88 & - & 65 & 58 & - \\
\hline $07 / 11 / 2006$ & 19 & 93 & 95 & - & 89 & 91 & - & 81 & 84 & - \\
\hline 07/19/2006 & 20 & 100 & 94 & - & 56 & 90 & - & 44 & 80 & - \\
\hline $07 / 22 / 2006$ & 21 & 89 & 89 & - & 86 & 83 & - & 79 & 62 & - \\
\hline $07 / 27 / 2006$ & 22 & - & - & - & - & - & - & - & - & - \\
\hline 08/06/2006 & 23 & 85 & 98 & - & 73 & 91 & - & 53 & 74 & - \\
\hline 08/17/2006 & 24 & 27 & 100 & - & 24 & 92 & - & 20 & 73 & - \\
\hline $08 / 23 / 2006$ & 25 & 55 & 98 & 86 & 51 & 95 & 80 & 45 & 80 & 68 \\
\hline \multirow[t]{3}{*}{$08 / 24 / 2006$} & 26 & 50 & 100 & 74 & 42 & 96 & 64 & 39 & 86 & 57 \\
\hline & Minimum & 27 & 89 & 74 & 24 & 77 & 64 & 20 & 58 & 57 \\
\hline & Maximum & 100 & 100 & 100 & 99 & 98 & 81 & 96 & 96 & 68 \\
\hline
\end{tabular}


Appendix 9. Particle-size distributions in stormwater samples collected at inlet, outlet, and bypass of hydrodynamic-settling device in Madison, Wisconsin, November 2005-August 2006.-Continued

[All data are in percent by mass; $<$, less than; $\mu \mathrm{m}$, micrometer; - , no sample processed]

\begin{tabular}{|c|c|c|c|c|c|c|c|c|c|c|}
\hline \multirow{3}{*}{$\begin{array}{l}\text { Sampling date } \\
\text { (month/day/year) }\end{array}$} & \multirow{3}{*}{$\begin{array}{c}\text { Sampling } \\
\text { event } \\
\text { number }\end{array}$} & \multicolumn{9}{|c|}{ Particle size } \\
\hline & & \multicolumn{3}{|c|}{$<63 \mu \mathrm{m}$} & \multicolumn{3}{|c|}{$<31 \mu \mathrm{m}$} & \multicolumn{3}{|c|}{$<16 \mu \mathrm{m}$} \\
\hline & & Inlet & Outlet & Bypass & Inlet & Outlet & Bypass & Inlet & Outlet & Bypass \\
\hline $11 / 27 / 2005$ & 1 & 64 & 50 & - & 55 & 35 & - & 48 & 24 & - \\
\hline $03 / 08 / 2006$ & 2 & 93 & 93 & - & 88 & 88 & - & 74 & 70 & - \\
\hline $03 / 12 / 2006$ & 3 & 90 & 92 & - & 81 & 86 & - & 59 & 76 & - \\
\hline $04 / 02 / 2006$ & 4 & 88 & 92 & - & 79 & 86 & - & 57 & 66 & - \\
\hline $04 / 12 / 2006$ & 5 & 79 & 83 & - & 70 & 71 & - & 50 & 50 & - \\
\hline $04 / 13 / 2006$ & 6 & - & - & - & - & - & - & - & - & - \\
\hline $04 / 16 / 2006$ & 7 & 42 & 57 & 43 & 34 & 44 & 31 & 24 & 29 & 20 \\
\hline $04 / 29 / 2006$ & 8 & 41 & 39 & - & 28 & 28 & - & 21 & 20 & - \\
\hline 05/01/2006 & 9 & 50 & 52 & - & 36 & 34 & - & 23 & 23 & - \\
\hline 05/09/2006 & 10 & 55 & 48 & - & 44 & 37 & - & 33 & 31 & - \\
\hline $05 / 11 / 2006$ & 11 & 55 & 47 & - & 46 & 36 & - & 40 & 31 & - \\
\hline $05 / 15 / 2006$ & 12 & - & - & - & - & - & - & - & - & - \\
\hline $05 / 16 / 2006$ & 13 & - & - & - & - & - & - & - & - & - \\
\hline $05 / 17 / 2006$ & 14 & 43 & 49 & - & 32 & 37 & - & 22 & 25 & - \\
\hline $05 / 24 / 2006$ & 15 & - & - & - & - & - & - & - & - & - \\
\hline $06 / 18 / 2006$ & 16 & 54 & 49 & - & 39 & 36 & - & 34 & 35 & - \\
\hline $06 / 25 / 2006$ & 17 & 39 & 36 & - & 29 & 27 & - & 25 & 24 & - \\
\hline $07 / 09 / 2006$ & 18 & 44 & 40 & - & 27 & 24 & - & 25 & 19 & - \\
\hline $07 / 11 / 2006$ & 19 & 56 & 61 & - & 37 & 40 & - & 29 & 37 & - \\
\hline $07 / 19 / 2006$ & 20 & 28 & 59 & - & 18 & 39 & - & 14 & 33 & - \\
\hline $07 / 22 / 2006$ & 21 & 54 & 40 & - & 36 & 29 & - & 35 & 29 & - \\
\hline $07 / 27 / 2006$ & 22 & - & - & - & - & - & - & - & - & - \\
\hline 08/06/2006 & 23 & 39 & 52 & - & 30 & 38 & - & 28 & 34 & - \\
\hline $08 / 17 / 2006$ & 24 & 16 & 54 & - & 13 & 44 & - & 12 & 36 & - \\
\hline $08 / 23 / 2006$ & 25 & 38 & 69 & 55 & 29 & 56 & 38 & 27 & 53 & 36 \\
\hline $08 / 24 / 2006$ & 26 & 34 & 74 & 51 & 29 & 63 & 45 & 27 & 61 & 42 \\
\hline & Minimum & 16 & 36 & 43 & 13 & 24 & 31 & 12 & 19 & 20 \\
\hline & Maximum & 93 & 93 & 55 & 88 & 88 & 45 & 74 & 76 & 42 \\
\hline
\end{tabular}


Appendix 9. Particle-size distributions in stormwater samples collected at inlet, outlet, and bypass of hydrodynamic-settling device in Madison, Wisconsin, November 2005-August 2006.-Continued

[All data are in percent by mass; $<$, less than; $\mu \mathrm{m}$, micrometer; - , no sample processed]

\begin{tabular}{|c|c|c|c|c|c|c|c|c|c|c|}
\hline \multirow{3}{*}{$\begin{array}{l}\text { Sampling date } \\
\text { (month/day/year) }\end{array}$} & \multirow{3}{*}{$\begin{array}{c}\text { Sampling } \\
\text { event } \\
\text { number }\end{array}$} & \multicolumn{9}{|c|}{ Particle size } \\
\hline & & \multicolumn{3}{|c|}{$<8 \mu \mathrm{m}$} & \multicolumn{3}{|c|}{$<4 \mu \mathrm{m}$} & \multicolumn{3}{|c|}{$<2 \mu \mathrm{m}$} \\
\hline & & Inlet & Outlet & Bypass & Inlet & Outlet & Bypass & Inlet & Outlet & Bypass \\
\hline $11 / 27 / 2005$ & 1 & 44 & 21 & - & 42 & 18 & - & 23 & 15 & - \\
\hline 03/08/2006 & 2 & 65 & 59 & - & 48 & 42 & - & 17 & 9 & - \\
\hline $03 / 12 / 2006$ & 3 & 49 & 63 & - & 35 & 46 & - & 11 & 12 & - \\
\hline $04 / 02 / 2006$ & 4 & 47 & 56 & - & 32 & 40 & - & 9 & 12 & - \\
\hline $04 / 12 / 2006$ & 5 & 39 & 40 & - & 28 & 29 & - & 7 & 7 & - \\
\hline $04 / 13 / 2006$ & 6 & - & - & - & - & - & - & - & - & - \\
\hline $04 / 16 / 2006$ & 7 & 19 & 24 & 15 & 15 & 17 & 10 & 4 & 5 & 2 \\
\hline 04/29/2006 & 8 & 19 & 18 & - & 16 & 15 & - & 6 & 8 & - \\
\hline 05/01/2006 & 9 & 17 & 19 & - & 12 & 13 & - & 4 & 3 & - \\
\hline $05 / 09 / 2006$ & 10 & 29 & 27 & - & 24 & 22 & - & 8 & 10 & - \\
\hline $05 / 11 / 2006$ & 11 & 37 & 29 & - & 33 & 24 & - & 15 & 9 & - \\
\hline $05 / 15 / 2006$ & 12 & - & - & - & - & - & - & - & - & - \\
\hline $05 / 16 / 2006$ & 13 & - & - & - & - & - & - & - & - & - \\
\hline $05 / 17 / 2006$ & 14 & 18 & 20 & - & 13 & 14 & - & 4 & 3 & - \\
\hline $05 / 24 / 2006$ & 15 & - & - & - & - & - & - & - & - & - \\
\hline $06 / 18 / 2006$ & 16 & 29 & 34 & - & 25 & 33 & - & 17 & 31 & - \\
\hline $06 / 25 / 2006$ & 17 & 21 & 19 & - & 17 & 15 & - & 8 & 7 & - \\
\hline $07 / 09 / 2006$ & 18 & 16 & 11 & - & 12 & 7 & - & 6 & 3 & - \\
\hline $07 / 11 / 2006$ & 19 & 22 & 33 & - & 16 & 28 & - & 9 & 19 & - \\
\hline $07 / 19 / 2006$ & 20 & 12 & 24 & - & 11 & 18 & - & 8 & 9 & - \\
\hline $07 / 22 / 2006$ & 21 & 32 & 26 & - & 26 & 22 & - & 13 & 9 & - \\
\hline $07 / 27 / 2006$ & 22 & - & - & - & - & - & - & - & - & - \\
\hline 08/06/2006 & 23 & 27 & 31 & - & 26 & 29 & - & 24 & 23 & - \\
\hline $08 / 17 / 2006$ & 24 & 10 & 27 & - & 8 & 21 & - & 5 & 14 & - \\
\hline $08 / 23 / 2006$ & 25 & 23 & 45 & 32 & 21 & 37 & 29 & 16 & 26 & 26 \\
\hline \multirow[t]{3}{*}{$08 / 24 / 2006$} & 26 & 22 & 51 & 32 & 14 & 35 & 20 & 5 & 13 & 7 \\
\hline & Minimum & 10 & 11 & 15 & 8 & 7 & 10 & 4 & 3 & 2 \\
\hline & Maximum & 65 & 63 & 32 & 48 & 46 & 29 & 24 & 31 & 26 \\
\hline
\end{tabular}


Appendix 10. Loads of suspended solids, adusted suspended solids, volatile solids, and dissolved solids in stormwater samples collected at inlet, outlet, and bypass of hydrodynamic-settling device in Madison, Wisconsin, November 2005-August 2006.

[All data in pounds; - - no sample processed]

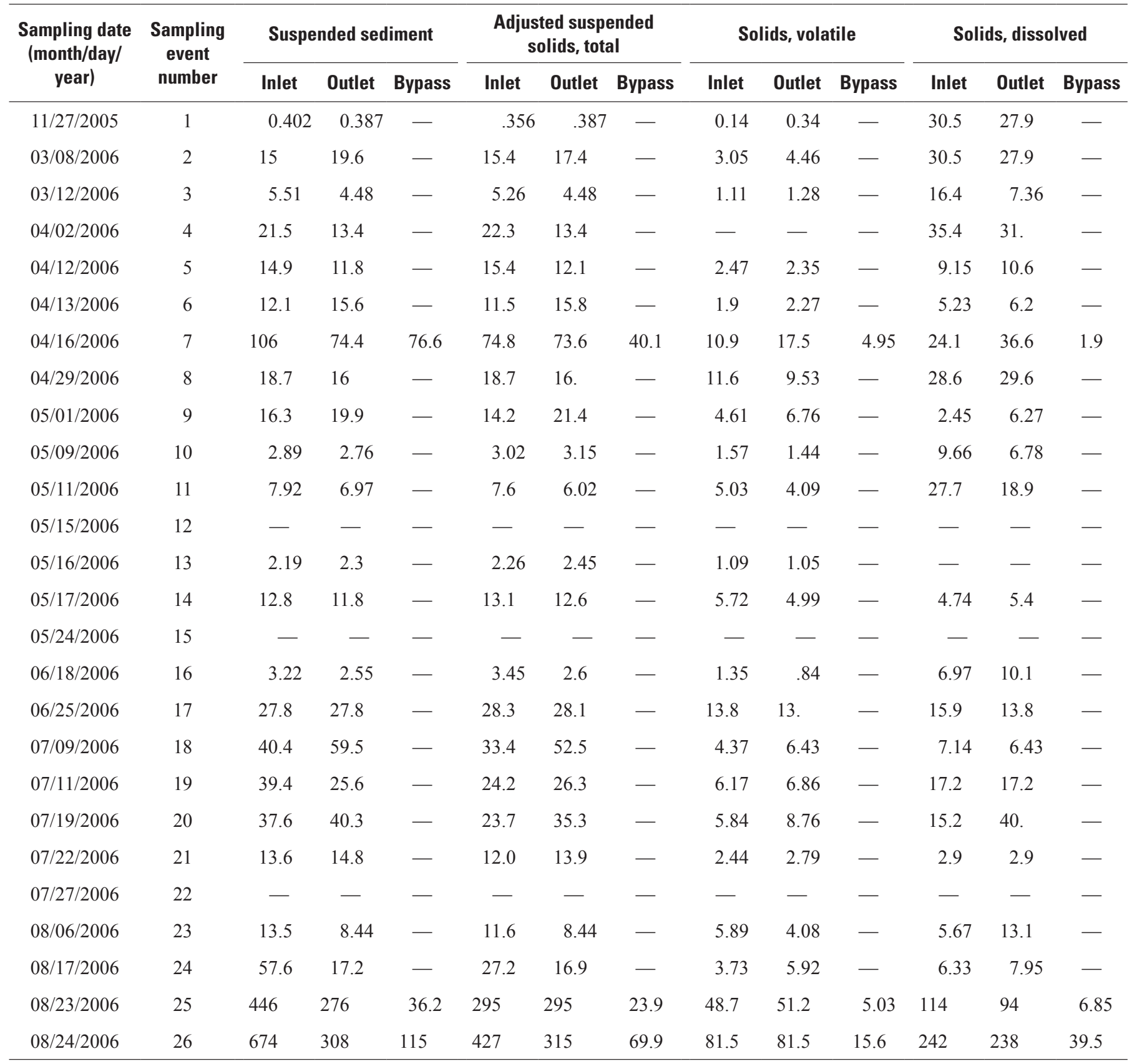


Appendix 11. Loads of selected water-quality constituents in stormwater samples collected at inlet, outlet, and bypass at hydrodynamic-settling device in Madison, Wisconsin, November 2005August 2006.

[All loads in pounds; - , no sample processed]

\begin{tabular}{|c|c|c|c|c|c|c|}
\hline \multirow{2}{*}{$\begin{array}{c}\text { Sampling } \\
\text { event } \\
\text { number }\end{array}$} & \multicolumn{3}{|c|}{$\begin{array}{c}\text { Phosphorus, } \\
\text { dissolved }\end{array}$} & \multicolumn{3}{|c|}{$\begin{array}{c}\text { Zinc, } \\
\text { total recoverable }\end{array}$} \\
\hline & Inlet & Outlet & Bypass & Inlet & Outlet & Bypass \\
\hline 1 & 0.0025 & 0.0034 & - & - & - & - \\
\hline 2 & 0.0042 & 0.0038 & - & 0.0054 & 0.0077 & - \\
\hline 3 & 0.0026 & 0.0024 & - & 0.0018 & 0.0021 & - \\
\hline 4 & 0.0114 & 0.01 & - & 0.0081 & 0.0063 & - \\
\hline 5 & 0.0037 & 0.0042 & - & 0.0044 & 0.0042 & - \\
\hline 6 & - & - & - & - & - & - \\
\hline 7 & 0.0187 & 0.0148 & 0.0027 & 0.0174 & 0.0187 & 0.0104 \\
\hline 8 & 0.0159 & 0.0238 & - & 0.0101 & 0.0111 & - \\
\hline 9 & 0.0028 & 0.0026 & - & 0.0044 & 0.0061 & - \\
\hline 10 & 0.0059 & 0.0047 & - & 0.003 & 0.0039 & - \\
\hline 11 & 0.0311 & 0.0315 & - & 0.0057 & 0.0057 & - \\
\hline 12 & - & - & - & - & - & - \\
\hline 13 & - & - & - & - & - & - \\
\hline 14 & 0.0021 & 0.0025 & - & 0.0052 & 0.0045 & - \\
\hline 15 & - & - & - & - & - & - \\
\hline 16 & - & - & - & - & - & - \\
\hline 17 & 0.0146 & 0.022 & - & 0.0125 & 0.0249 & - \\
\hline 18 & 0.0061 & 0.0057 & - & 0.0089 & 0.0115 & - \\
\hline 19 & 0.0384 & 0.0357 & - & 0.0117 & 0.0123 & - \\
\hline 20 & 0.0117 & 0.0105 & - & 0.0117 & 0.0146 & - \\
\hline 21 & 0.0049 & 0.0014 & - & 0.0042 & 0.0048 & - \\
\hline 22 & - & - & - & - & - & - \\
\hline 23 & 0.0168 & 0.0129 & - & 0.0082 & 0.007 & - \\
\hline 24 & 0.0071 & 0.0046 & - & 0.0083 & 0.0104 & - \\
\hline 25 & 0.9488 & 0.7339 & 0.0458 & 0.0801 & 0.083 & 0.009 \\
\hline 26 & - & - & - & - & - & - \\
\hline
\end{tabular}


Publishing support provided by the U.S. Geological Survey Science Publishing Network, Columbus Publishing Service Center

For more information concerning the research in this report, contact the: Director, Wisconsin Water Science Center U.S. Geological Survey 8505 Research Way Middleton, Wisconsin 53562 http://wi.water.usgs.gov/ 


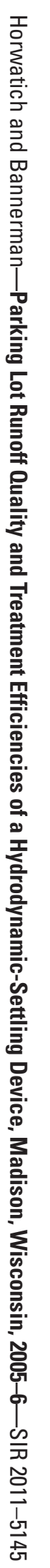

